\title{
THE COMMERCIAL COMMONWEALTH
}

The brothers De la Court were still in their mid-twenties when they sought permission from the Leiden court to start an independent textile business. ${ }^{1}$ With the establishment of their joint firm in March 1645, the brothers aimed at a vertical concentration of the various stages of textile manufacturing and trade: they provided the capital for the purchase of pure woollen materials, they set up a central atelier at their own house and a dyeworks where a group of employees processed the wool, and they were themselves responsible for putting the finished product on the market. The De la Courts thus bypassed intermediary producers and traders, and as so-called reders they became the patrons of an entirely selfsufficient business that went well beyond the system of 'small commodity production' characteristic to the earlier stages of Leiden's economic development. $^{2}$ Thanks to their father's wealth and experience, the brothers were able to make the large investments needed for this new, earlycapitalist type of entrepreneurship, which was soon to dominate the textile industry in Leiden. ${ }^{3}$

The firm 'Pieter and Johan de la Court' would prove to be very successful. By the end of the 1650 , it had become a thriving firm that manufactured and exported cloth and camlet from Leiden all over Europe, from the Baltic to the Mediterranean. The brothers' joint capital amounted to the substantial sum of 76000 guilders, mainly invested in readymade cloth and loans. ${ }^{4}$ The De la Courts were active at the apogee of the Leiden textile

\footnotetext{
1 The petition is printed in N.W. Posthumus (ed.), Bronnen tot de geschiedenis van de Leidse textielnijverheid, 6 vols. (The Hague: Nijhoff, 1910-1922), vol. IV: 429.

${ }^{2}$ Cf. Robert S. DuPlessis and Martha C. Howell, "Reconsidering the Early Modern Economy: The Cases of Leiden and Lille," Past and Present 94 (1982), 49-84.

3 See Van Tijn, "Pieter de la Court," 306-307, 312-315; and N.W. Posthumus, De geschiedenis van de Leidsche lakenindustrie II: De nieuwe tijd, 2 vols. (The Hague: Martinus Nijhoff, 1939), 548. Posthumus' standard work is critically surveyed in J.G. van Dillen, "Leiden als industriestad tijdens de Republiek," Tijdschrift voor Geschiedenis 59 (1946), $25^{-51}$. For a more recent and more lucid introduction to the early-modern economic history of Leiden, see Boudien de Vries et al., "Het economische leven: spectaculair succes en diep verval," in Groenveld (ed.), Leiden, 85-107.

4 See the inventory of De la Court's possessions in Kernkamp (ed.), "Brieven (16671685)," 148-161. For the De la Courts' relative prosperity, cf. Israel, Dutch Republic, 633.
} 
business, which was by then the largest in Europe and employed more than half of the city's population. Leiden, the city where they were born, where they had studied and where they made their fortune, would be the prime empirical foundation of the brothers' analysis of the challenges and perspectives of a commercial commonwealth.

This chapter shows how the De la Courts' critical analysis of the economic policies of their hometown engendered a radical critique of the principle of monarchy and a related plea for a broad aristocratic government close to democracy. My central argument is that these two crucial characteristics of the brothers' republicanism follow from their distinctive portrayal of a commercial society where liberty reigns. The De la Court modelled their ideal republic on the experience of Leiden, whose fate as a mercantile, self-contained and pacifist city reflected the example of ancient Athens. On the basis of their critical assessment of Leiden's policies, they constructed a commercial reason of state theory that centres on an inclusive notion of republican liberty, merging freedom from economic interference with freedom from arbitrary domination. This comprehensive idea of liberty results in the claim that all forms of monarchy are necessarily tyrannical, a claim with clear implications for the Dutch debate on the position of the Stadholder. The commercial emphasis of their thought leads to the brothers' argument for a broad republican assembly consisting of wise merchants. This radically anti-monarchical and tentatively democratic move is particularly significant in comparison with the De la Courts' republican contemporaries in England.

\section{The Batavian Athens}

\section{Urban Reason of State: Debating Leiden's Welfare}

At the start of their first treatise, Het welvaren van Leiden, the De la Courts stated explicitly that the politics of their hometown should be conceived "sopra la raggion di Stato". From the outset, they thus positioned themselves in the tradition of reason of state. This intellectual current comprised a heterogeneous array of political treatises that, from the end of the sixteenth century onwards, flooded the European markets with intricate accounts how to preserve and enlarge a dominion according to the notorious adage 'necessity has no law'.5 One of the first and foremost

${ }^{5}$ See for useful overviews esp. Burke, "Tacitism, Scepticism, and Reason of State"; Stolleis, Staat und Staatsräson; and Viroli, From Politics to Reason of State, 238-280. 
contributions to this tradition was Giovanni Botero's Della ragion di stato, first published in 1589. Botero's definition of reason of state as "the knowledge of the means of establishing, preserving and enlarging a Dominion" became the leading premise of most subsequent reason of state literature, for example of the Duke of Rohan's influential tract De l'interest des princes. ${ }^{6}$ Following this definition, the De la Courts similarly asserted that Leiden's welfare was to be found in "the Conservation and the increase of the Republic of Leiden and its human society consisting of Rulers and Subjects". ${ }^{7}$ Yet this phrasing reveals a significant difference from the conventional reason of state literature, including Botero and Rohan, for whom the term 'state' meant the personal dominion and status of a prince. ${ }^{8}$ For the De la Courts, the state involved the collective body of both rulers and ruled, i.e. the city or commonwealth at large - the traditional idiom of the Italian Renaissance republics. ${ }^{9}$ Botero, in another treatise titled Delle cause della grandezza delle città, often appended to Della ragion di stato, also spoke about the reason of state of cities, yet still with a focus on the central role of a prince and his residence. ${ }^{10}$ The brothers De la Court adopted Botero's guidelines for a self-governing city like Leiden, merging the republican legacy with the language of reason of state.

According to the conventional reason of state logic, Leiden posed a difficult case. Botero had argued that the grandezza of cities consists in the quantity of the people and their belongings, for which, apart from the splendour of a princely court, a favourable geographical position and fecund surroundings are essential. ${ }^{11}$ Yet Leiden, as the De la Courts insisted, lacked all these assets. Therefore, the city should resort to two highly unpredictable means of attaining civic grandezza: the world of learning, embodied by Leiden's famous university, and the world

${ }^{6}$ Giovanni Botero, Della ragion di stato e delle cause della grandezza delle città (Venice, 1598) I, p. 1: "Ragione di Stato è notitia di mezi atti a fondare, conservare, e ampliare un Dominio cosí fatto." Cf. the similar terminology in Rohan, De l'interest des princes, 101.

7 Welvaren 1, p. 3: "Sullende mine gedaghten laten gaen, sopra la raggio di Stato, over 't Welvaren der Stad Leiden, soo moet in 't begin werden geseid, dat ick daer mede verstae de Conservatie ende vermeerderingh der Leidsche Republieke, en menschelicke societeit bestaande uijt Regeerders ende Onderdanen."

8 Cf. Botero, Della ragion di stato I, p. 1: "Stato è un dominio fermo sopra popoli ... la Ragione di Stato suppone il principe."

9 Cf. e.g. Aanwsying I.24, p. 118: “... de politike Regeerders, over alle Onderdaanen gesaamentlik een Politik lighaam uitmaakende, welke wy den Staat noemen." On the shifting vocabulary of the state in early-modern Europe, see Quentin Skinner, "From the State of Princes to the Person of the State," in Idem, Visions of Politics, vol. II: 368-413.

${ }^{10}$ Botero, Cause della grandezza delle città, esp. 351-366.

"Ibidem, 309, 318-330. 
of industry and trade. ${ }^{12}$ Leiden's population and riches pivoted on the mutual enhancement of commerce and learning, for "inside the walls of the City the inhabitants have no other means to subsist than those provided by the powers of the soul and the human body, that is, sciences, arts, and manufacturing ... and to trade [these] with strangers for good profits". ${ }^{13}$ The main aim of the De la Courts' treatise on Leiden was to convince the city's establishment to uphold the two central pillars with which they themselves were so well-acquainted: the academy and the market.

This notion that Leiden's welfare depended on the correlation between learning and trade was a standard element of the city's self-representation in the seventeenth century, both in word and in image. For example, the former Burgomaster Jan Orlers praised Leiden in his eulogizing chronicle of the city as a "Dutch Helicon" where industry thrived thanks to divine providence and good government. ${ }^{14}$ The painter Van den Tempel (who later portrayed De la Court and his second wife) celebrated this shared fate of Leiden and its textile industry in three large panels commissioned in the immediate aftermath of the Peace of Westphalia. The first of these panels shows how the personification of the city's industry, escorted by Minerva and Mercury, flees from the destruction brought by Mars, who tramples the figures of Freedom and Justice. In the central piece, the Maid of Leiden is crowned by Minerva under the city's motto "Haec libertatis ergo", while Justice kneels and Mercury reveals his full purse. Finally, in the third panel (see colour plate D), the splendidly dressed Maid of Leiden invites the personification of industry to her stage. At the front, Freedom offers her emblematic attributes to the city; at the left, Minerva and Mercury witness the scene. Mercury's hand rests on Minerva's shoulder: commerce embraces wisdom. ${ }^{15}$

\footnotetext{
${ }^{12}$ Welvaren 1, p. 3-5. Cf. Botero, Cause della grandezza delle città, 339-348.

${ }^{13}$ Welvaren 4, p. 11: “... dat de ingeseetenen binnen de mueren der Stad geene middelen van subsistentie besitten, als die der kraghten der zielen ender menschelijke lichamen verschaffen konnen, Namentlijck wetenschappen, konsten ende handwerken ... hier konnen veijlen en verkopen met geode profijten aen vreemden."

${ }^{14}$ Jan Orlers, Beschrijvinge der Stadt Leyden, 2d. ed. (Leiden, 1641), sig. "** " Helicon.” See also Leonore Stapel, "'Tuyn van heel Holland, Moeder der Wijsheyt en bequam tot de drapery.' Reputatie en zelfbeeld van Leiden in beeld en tekst (circa 15901660)," De zeventiende eeuw 22 (2006), 149-169.

${ }^{15}$ See Linda A. Stone-Ferrier, Images of Textiles. The Weave of Seventeenth-Century Dutch Art and Society (Ann Arbor: UMI Research Press, 1985), 32-34; and Christiaan Vogelaar, "Abraham van den Tempel," in Hollands Classicisme in de Nederlandse schilderkunst (Rotterdam: Museum Boijmans van Beuningen, 2000), 254-263.
} 
In their discussion of Leiden's reason of state, the brothers De la Court borrowed many elements of this iconographical representation of a city in which peace and liberty reign and commerce and learning go hand in hand. Yet their approach was fundamentally more critical of Leiden's status quo than mainstream eulogies such as that of Orlers. They engaged in a fervent criticism of the corporate politics of Leiden's society, based on the primacy of guilds and municipal economic regulation. As independent entrepreneurs and relative newcomers to the Leiden textile industry, they looked at Leiden's economy from within yet with the critical eye of the outsider. This approach resulted in a passionate and remarkable plea for an 'open' city where entrepreneurial liberty fosters prosperity, in opposition to the traditional closed urban system of comprehensive corporate regulation. ${ }^{16}$

The textile industry of early-modern Leiden was organized in various communal institutions, usually installed by the municipal government, which administered and controlled the production and trade of all commodities. Every single branch of the industry was represented by its own corporative association, the so-called nering, presided over by members of the government and wealthy delegates of the industry. Like guilds, the various neringen regulated the production and imposed obligatory inspections of the textiles in a centrally located hall. Through the establishment of such halls, the municipal government sought to support the small producers, the drapers. In exchange for a levy on every article, the hall provided independent producers with opportunities to hire equipment and to purchase raw materials, as well as a marketplace to sell their products. In this way, the system of neringen and halls minimised entrepreneurial risks and maintained industrial stability, which attested to the ideological commitment of both the authorities and the drapers to sustain the order and prosperity of the community. ${ }^{17}$

In 1642 , the Leiden government installed a hall for the commerce of laken, a relatively new form of cloth that had become very fashionable and highly lucrative. The firm of the brothers De la Courts traded primarily in

\footnotetext{
${ }^{16}$ Jan de Vries and Ad van der Woude, The First Modern Economy. Success, Failure, and Perseverance of the Dutch Economy, 1500-1815 (Cambridge: Cambridge University Press, 1997), 175-176.

${ }_{17}$ See DuPlessis and Howell, "Reconsidering," esp. 59-62, and the reworking of their argument in Karel Davids, "Neringen, hallen en gilden. Kapitalisten, kleine ondernemers en de stedelijke overheid in de tijd van de Republiek," in C.A. Davids et al. (eds.), Kapitaal, ondernemerschap en beleid. Studies over de economie en politiek in Nederland, Europa en Azië van 1500 tot heden (Amsterdam: NEHA, 1996), 95-119.
} 
laken, and from the start, independent reders like the De la Courts opposed the establishment of the hall and its legislation, levies, and control. Together with a large group of other producers and traders, the De la Courts addressed their complaints to the Leiden court in 1653. They argued that "there is no better way conceivable to ruin the entire cloth industry of this city" than the hall's regulation of the production, which they denounced as "incompatible with the freedom and nature of trade". ${ }^{18}$ A few years later, the brothers De la Court further elaborated this argument against economic regulation in their treatise on Leiden, following their initial claim "that Leiden has never increased but by Liberty": ${ }^{19}$ the preservation and enlargement of the commonwealth, they asserted, the prime principles of reason of state, could only be furthered if all its citizens were allowed to do business as they please.

The De la Courts primarily insist that the success of Leiden's trade and industry is based on the consumption of its goods outside of the city walls, and is therefore entirely dependent on the mercantile reders. Small producers and petty artisans can only be employed thanks to the investments and success of these large entrepreneurs, especially of those who export Leiden textile across the borders. ${ }^{20}$ Since the largest profits are made in international trade, "these international Merchants are the most profitable inhabitants and they enrich the country the most". ${ }^{21}$ Yet they can only make such high revenues if they are left unhindered in their decisions, for "he who has to eat the porridge cooks and cools it best":

Everyone ought to be totally free and unrestrained in producing and dealing with his own commodity ... Where everyone takes care of himself, everyone is fine, and no one gets lost. This is the natural liberty that the Rulers should never take away from their subjects. ${ }^{22}$

${ }^{18}$ Posthumus (ed.), Bronnen, vol. IV: 498-501: “... strijdich tegen de vrijheyt ende natuyr van coopmanschap ... alsoo daer geen souverainder middel te bedencken is om de gantsche lakenneeringe deses stadts te ruyneeren." For other examples of the resistance of the reders against the system of halls, see Van Tijn, "Pieter de la Court," 315-321.

${ }_{19}$ Welvaren 11, p. 30: " dat Leiden noijt is toegenoomen, als door Vrijheid."

${ }^{20}$ Ibidem 16. Cf. the similar argument in Henry Parker, Of a Free Trade (London, 1647), 31: "If the question then be, whether the Merchants interest, or the Clothiers do more conduce to this publick reason of State; sense it self will presently distinguish, that the Merchants advantage is more compliant with the publick then the Clothiers."

${ }^{21}$ Politike Discoursen I.I.1, p. 9: "... sulks deese buitenlandse Handelers, de aller profitelikste ingeseetenen, ende die het land allermeest verryken, zijn."

${ }_{22}$ Welvaren 16, p. 44: "En die de pap selvs eeten moet, kookt en koelt se best ... een ijder in 't maken van sijn eigen goed, ende besteden desselvs gansch vrij en onbedwongen behoorde te weesen ... daer een ijder sich selven soekt, vind men sich best, en gaet niemand verlooren. Dit is de naturelijcke vrijheid, die de Regeerders noit hunne onderdanen behoorden te beneemen." 
The core assertion of De la Courts is that the system of halls and guilds fundamentally obstructs such natural liberty - and hence, Leiden's reason of state. The halls are governed by oligarchic boards of inexperienced people "who never fail to advise to their own advantage, even if it is obviously to the disadvantage of the community". Driven by such wrongly understood self-interest, the governors of the halls will simply try to fill their own purses under the pretext that they care for the common good, "using that nice cover of wanting to make the Industries eternal". ${ }^{23}$ Yet the hall's rigid system of regulation cannot obtain that goal of eternity given the vicissitudes of international trade. As the De la Courts insist, "none of our industries is fixed to the ground, and therefore they do not resemble the trees, from which one may cut some branches that bear little fruit". ${ }^{24}$ In the realm of commercial Lady Fortune, characterized by cross-border competition and the capriciousness of fashion, a pragmatist mercantile virtù is necessary to maintain Leiden's industry and to improve its competitiveness. As De la Court put it in 1657 when discussing the regulations concerning the production of camlet with his entrepreneurial colleagues: "Persist with liberty. Otherwise, the industries will divert." 25

The De la Courts therefore contend that all sorts of commodities, of whatever quality or price, should be put on the market, irrespective of the hall's obligatory controls. The resulting increase in production would do justice to "the right reputation of the Industries, [which] consists in the ability to provide honest work for the largest number of people". ${ }^{6}$ Opening up the market fosters general employment and the common welfare, whereas corporate regulation would result in the direct opposite. As the De la Courts conclude emphatically: "The poison of the Halls is deadlier to the draperies than the bloody swords of looting soldiers." ${ }^{27}$ With equally vehement language, they continue to reproach the economic policies of the guilds, the central institution of early-modern Dutch corporate

${ }^{23}$ Ibidem 23, p. 56-57: “... die missen noit tot hun eigen voordeel te raden, al is het kennelijck tot nadeel van 't gemeen ... soo gebruijcken sij evenwel die schone dekmantels van de Neeringe eeuwighdurende te willen maecken." See also Ibidem 28.

${ }^{24}$ Ibidem 26 , p. 61 “... dat geen onser neeringen aen onse grond vast sijn, en dat sij dienvolgende de boomen niet gelijcken, daer men eenige weinigh vrughtdragende tacken mach afsnijden."

${ }^{25}$ Posthumus (ed.), Bronnen, vol. V: 282: "Persisteert bij de liberteyt. De neringe (anders) te sullen diverteren."

${ }^{26}$ Welvaren 31, p. 68: “... de reghte reputatie der Neeringen bestaet in de bequaemheid, om aen het grootste getal menschen hier eerlijck den kost te geven."

${ }_{27}$ Ibidem 34, p. 74: “... het vergift der Hallen doodelijcker is voor draperien, als de bloedige swaerden der plonderende soldaeten." 
politics. ${ }^{28}$ Like the halls, the exclusivist policies and unifying regulations of the various guilds are "a special pest for Leiden" which obstruct economic freedom and overall prosperity. Guildsmen, who "live lazily and wastefully at the expense of the other inhabitants" embody the prime characteristic of incivility - the desire for domination. To counter this "filthy tyranny and the monopoly of the guildsmen and the Governors of the Halls over their fellow inhabitants", all production should be deregulated, wages should be set free, levies and cartels abolished and every one should be able to choose with whom to trade. ${ }^{29}$ Such economic freedom will increase manufacturing, attract foreigners, and thus enhance Leiden's overall grandezza, for "Liberty is Leiden's welfare". ${ }^{30}$

The second pillar of Leiden's reason of state, next to trade and industry, is its university, which according to the De la Courts requires an equal degree of liberty. The brothers maintain that commerce and science are strikingly similar endeavours that require a similar approach, for "it is impossible to have such uncertain inhabitants who will leave so easily as Students or merchants in a country town" ${ }^{31}$ Just like its merchants, Leiden's students should therefore be cherished and granted freedom of choice. Yet Leiden's policies are very unfavourable to the student body, so the De la Courts claim. As in the textile industry, regulations and monopolist exploitation undermine the advancement of science and they chase students away. Tuition fees have become too high, the Professors, who operate like a guild, "have openly founded a Government within a Government", while the university's senate, like the boards of the halls, "has degenerated from a laudable aristocratic government into an altogether detrimental Stato da Pochi [sic] Government", an oligarchy based on cooptation and characterised by incompetence.$^{32}$ In short, commerce and learning prove to be intrinsically related. For the De la Courts, the status quo of Leiden's academy and market are a clear demonstration of

${ }^{28}$ See Maarten Prak et al. (eds.), Craft Guilds in the Early Modern Low Countries. Work, Power, and Representation (Aldershot: Ashgate, 2006).

${ }^{29}$ Welvaren 46-52, p. 104, 110, 118: “... een bijsondere pest voor Leiden ... om leuij en quistich ten laste der andere ingesetenen te leeven ... de vuijle tijrannie ende monopolie der gildebroederen, ende gouverneuren der Loijhallen over hunne mede ingesetenen." Cf. the similar passages in Politike Discoursen I.I.1, p. 5-7, I.I.6, p. 57-59.

$3^{\circ}$ Groningen University Library, Ms 233, addendum: "Vrijheid is Leidens welvaren."

${ }^{31}$ Welvaren 8, p. 19: “... onmogelijk is het, soo onseeckre inwoonders te hebben, en die soo licht vertrekken sullen, als Studenten, of wel koopluiden van een Landstad."

$3^{2}$ Ibidem 14, p. 33-35: “... met die loffelijcke aristocraticke regeeringe te doen degenereeren in een altoos schadelijcke Stato da Pochi, Regeeringh ... ende opentlijck opgereght eene Regeeringh in Regeeringe." 
what happens when freedom is restrained and when office-holding is not based on merit but on favouritism. The distinctive idiom in which they criticize this status quo reveals the political implications of their plea for economic deregulation.

The urban reason of state of the brothers De la Court principally aims to defend the position of Leiden's independent entrepreneurs against the regulative and exclusivist policies of the city's corporate establishment. Leiden is a diverse society, the brothers insist, it is characterized by the "endless natural division" of its inhabitants which is "that large, that no larger can be imagined when seeing so many Nations, Languages, Religions and occupations as are here assembled". ${ }^{33}$ This diversity should be cherished and enhanced instead of curtailed, for diversity breeds competition and competition breeds prosperity, in the economic as well as in the academic realm. If the Senate of Leiden University could change from an oligarchy into a broad assembly of diverse professors and lecturers, the resulting mutual envy would cause widespread ambition to "teach the Students in the most diligent way". ${ }^{34}$ Diversity thus channels human selflove towards a useful purpose. At the level of society at large, a polity that includes a variety of immigrants, creeds, and professions will engender the welfare and happiness of all, for its inhabitants will then be able to choose from all kinds of produce, employers and preachers, and from "a variety of people with whom to make friendship and to converse". In such an open and diverse city, abundance is assured and hunger rare thanks to "the multiplicity of merchants and artisans", whose presence assures a constant import and production of food and goods. Science and knowledge, arts and music are bound to flourish in all freedom and variety. ${ }^{35}$ The brothers De la Court do not hesitate to claim that their model of an open city amounts to a true commercial arcadia.

\section{Paragons of Republican Splendour \& Demise}

A standard element of many reason of state treatises was the comparison with other polities from the past and the present as noteworthy examples

\footnotetext{
${ }_{33}$ Ibidem 73, p. 160: “... een oneindelijcke naturelijcke verdeeldheid ... jae soo groote, dat geen grooter kan werden bedaght, als te sien, soo veelderleij Natien, Talen, Religien en occupatien, als hier bij een sijn.”

${ }^{34}$ Ibidem 68, p. 148: “... den Studenten, door die jalousie, ambitie, ende nijd op het vlijtighste te onderwijsen."

${ }_{35}$ Politike Discoursen I.I.2, p. 40-41: “... keur van menschen, met wien men vriendschappen maken ende converseeren wil ... door de meenigvuldigheid der negotianten ende konstenaars."
} 
of statecraft. In their depiction of Leiden's arcadia amidst which industry and learning thrive in liberty and diversity, the brothers De la Court too referred to such paragons of republican splendour. Haitsma Mulier has shown in detail how the De la Courts appropriated in particular the commercial republics of the early-modern Mediterranean, which by the end of the 1650 s were a common point of reference for both sides of the Dutch debate on 'True Liberty'. The brothers paid ample attention to Venice and Genoa, outstanding examples of prosperous and powerful, yet conservative aristocracies, ${ }^{36}$ and, less extensively, to the small cities of Lucca and Ragusa (modern-day Dubrovnik), which shared Leiden's perspective and geographical hardship. Adopting the typical reason of state description of various countries by the sixteenth-century Venetian polygraph Francesco Sansovino, ${ }^{37}$ the De la Courts praised these commercial citystates for preserving their independence and wealth in a hostile world: the inland town of Lucca "has by good government and Fortification maintained its liberty and abounds in men, arts, and Industries", while Ragusa, though surrounded by infertile land and mighty neighbours, has thrived "in freedom and wealth".$^{8}$ This praise for Ragusa is especially significant, for it reveals a striking parallel with the way in which the contemporary English republican John Streater propagated Ragusa's republican government as the "true Embleme of a Free-State". 39

Yet the primary source of inspiration for the De la Courts' ideal of industry and learning continued to be Antiquity. In particular, they

${ }^{36}$ Politike Weeg-schaal II.III.2-II.IV.12 and II.V.1-11. See the elaborate analysis in Haitsma Mulier, Myth of Venice, 147-157.

${ }^{37}$ Francesco Sansovino, Del governo et amministratione di diversi regni et repubbliche, cosi antiche come moderne (Venice, 1568), esp. 111-115, 146-149. Pieter de la Court van der Voort owned a copy of this work: Library, fol. 19. On Sansovino, see Viroli, From Politics to Reason of State, 243-244, and Paolo Carta, "Magistrature repubblicane e comparazione giuridica nell'opera di Francesco Sansovino," Il pensiero politico 40 (2007), 283-300.

${ }_{38}^{8}$ Politike Weeg-schaal II.IV.13, p. 427: “...in vryheid, en weelde." Ibidem III.I.IV, p. 535: “... kleine Lucca, een Lant-stad, door een goede regeering, en Fortificatie sijn vryheit, hebbende behouden, overvloeit in menschen, konsten, en Manufacturen." See also Welvaren 58, p. 134-135. Cf. the comparison between the mercantile republics of Ragusa, Lucca, and seventeenth-century Boston in Sergio Bertelli, Trittico. Lucca, Ragusa, Boston. Tre città mercantili tra Cinque e Seicento (Rome: Donzelli, 2004). On the development of a republican rhetoric in Ragusa, see Lovro Kuncevic, "On Ragusan Libertas in the Middle Ages," Dubrovnik Annals 14 (2010), 25-69.

39 [John Streater], Government Described ... Together With a Brief Model of the Government of the Common-Wealth, or, Free-State of Ragouse (London, 1659), 8. The phrasing of Streater's description of Ragusa is comparable to the Politike Weeg-schaal, and equally stems from Sansovino. On Streater, see Nigel Smith, "Popular Republicanism in the 165os: John Streater's 'Heroick Mechanicks'," in David Armitage et al. (eds.), Milton and Republicanism (Cambridge: Cambridge University Press, 1995). 
followed the prevalent comparison between Leiden and classical Athens, the foremost historical example of a republic that accommodated both the agora and the academy. In 1625, Joannes Meursius, professor of Greek history at Leiden University, had published a remarkable eulogy of the first decades of his alma mater under the title Athenae Batavae..$^{40}$ Similarly, the poet Jacob Lescaille praised Leiden as a "Batavian Athens", the site of both Apollo's temple and Pallas' court, ${ }^{41}$ while Vondel too heralded Leiden as "The new Athens". ${ }^{42}$ This scholarly and literary identification with Athens was elaborated further by the De la Courts. Their fascination was shared by English political pamphleteers such as Marchamont Nedham, who described Athens as "the onely Patern of a Free-state fit for all the world to follow". ${ }^{43}$ While Harrington, like Machiavelli, focused primarily on militant Sparta and Rome, his more commercially-minded contemporaries on either side of the North Sea turned to other republican role models in the classical and contemporary Mediterranean. ${ }^{44}$

Not unlike Nedham, the brothers De la Court presented Athens as a paradigmatic popular government, a truly commercial city-state that could serve as a model for Leiden. Apart from obvious sources such as Herodotus and Thucydides, this interpretation of Athens owed a particular debt to the overview of the history of Greek city-states by the Frisian historian Ubbo Emmius, a work included in the 'Republics' series of Elzevier. Emmius had characterized all Greek republics as status popolares, which principally implied that the citizenry enjoyed the right to elect the republic's magistrates. ${ }^{45}$ This usage of the term 'popular government' is adopted

\footnotetext{
$4^{40}$ See Anthony Grafton, Athenae Batavae: The Research Imperative at Leiden, $1575^{-1650 .}$ Scaliger Lectures 1 (Leiden: Primavera, 2003).

${ }^{41}$ Jacob Lescaille, "Lof van Leiden," in Toonneel der steden van de Vereenighde Nederlanden, met hare beschrijvingen (Amsterdam, 1652), vol. I, fol. ii D4 d: "O moedig Leiden! ... O voedster van de deugd/En alle wetenschap! Toneel der wijste lieden,/Apollo's tempel, hof van Pallas, wier gebieden/Gij loffelijk bestuurt! Sieraad van 't vrije land,/Der muzen woonplaats en voortteelster van verstand,/Voorspreekster van het recht, geneesvrouw der gebreken,/Die alle volken doet van uwe wijsheid spreken./Bataafs Athene! Leef door voorzicht, trouw en raad/En vreê en voorspoed, als de zuilen van uw staat."

${ }_{42}$ Joost van den Vondel, "Op de geluckige regeeringe van Leiden" (1664), in De werken van Vondel, ed. J.F.M Sterck et al., 11 vols. (Amsterdam: Maatschappij voor goede en goedkope lectuur, 1927-1940), vol. X, 176: "Het nieuwe Athene groeit, nu 't oude in d'assche leit."

43 [Marchamont Nedham], The Excellencie of a Free-State: or, The Right Constitution of a Common-wealth (London, 1656), 8. On Nedham's description of Athens, see Jennifer Tolbert Roberts, Athens on Trial. The Antidemocratic Tradition in Western Thought (Princeton: Princeton University Press, 1994), 145-147.

44 Cf. Pincus, "Neither Machiavellian Moment nor Possessive Individualism," 724.

45 Ubbo Emmius, Vetus Graecia illustrata (Leiden, 1626), and Idem, Graecorum respublicae (Leiden, 1632). See the analysis in Conti, Consociatio civitatum, 86-104.
} 
in the extensive description of Ancient Greek history in the Politike Weeg-schaal. Following Emmius, this crucial passage, most certainly written by Johan de la Court with small revisions by Pieter, implicitly compares the republican fate of Athens with Leiden and Holland at large. ${ }^{46}$ To begin with, the brothers De la Court highlight the geographical situation of Athens, a maritime city amidst barren lands and therefore forced to make a living by fishing and trade. The similarity with Leiden and Holland is obvious, and the De la Courts argue that Athens' commerce on the Black Sea, like the Dutch trade in the Baltic, had made it into the staple market of Europe. They stress that such commerce could thrive in Athens because of the city's prime characteristic, its "uniform Liberty": citizens as well as foreigners were allowed to trade and participate in all industries without the obstruction of "Patents, Privileges, or Guilds and Halls". Moreover, in Athens "all Citizens had the right to appear in its great Assembly", while mostly "rich and therefore well-educated Citizens were used in the Magistracy" - a practice of which the De la Courts clearly approve. ${ }^{47}$

However, Athens also had flaws. First, the De la Courts criticize its restrictions on the acquisition of citizenship, and insist that these restrictions created "a very large discontent among so many thousands foreign Inhabitants" and hence "a very large disposition to upheaval" ${ }^{8}$ In short, a policy of restrictive citizenship threatens the stability of the commonwealth, again a clear allusion to the situation in Leiden. Secondly, the De la Courts criticize the belligerent politics of Athens, "for nothing more detrimental to a State built on artisanship, trade and sciences can be thought of than all-destroying and commerce-impeding War". In contrast, amongst the "principal causes of Athenian greatness" was its defensive alliance with other Greek states against the Persians, the Attic league so often upheld in the Dutch debate as a noteworthy example for the United

${ }^{46}$ Politike Weeg-schaal III.II.1-III.II.4. The entire passage is already included in the first edition, with small revisions added to the later editions of the work. Cf. also the analysis in Haitsma Mulier, Myth of Venice, 143-144.

47 Ibidem III.II.1, p. 591: “... eenparige Vryheid.” III.II.2, p. 604, 614: “Alle Burgers hadden regt te verschijnen in haare groote Vergaderinge ... zeer weinig andere, als rijke, en dienvolgende wel-opgevoede Burgers in Magistrature wierden gebruikt." III.II.4, p. 620: "Van Octroyen, Privilegien, off Gildens en Hallen werd naar my voorstaat, in geen Historien van Atheenen gewag gemaakt."

${ }^{48}$ Ibidem III.II.2, p. 603: "Een yder stond vry te Athenen te komen woonen, en daar alle Vryheid en Regten nevens de Burgers te genieten.” III.II.4, p. 627: “... een zeer groot misnoegen onder zoo veele duisenden vremde Inwoonders ... een zeer groote dispositie ten oproer." 
Provinces. ${ }^{49}$ Finally, this suggestive comparison between Athens and Holland becomes all but outspoken when the De la Courts insist that Athens flourished in "Sciences and Arts" and "increased exceedingly in all luxury, art, knowledge, and wealth" when it was "under an entirely Popular Government without any Head, or permanent Councillors and Magistrates".$^{\circ}$ The history of Ancient Athens thus serves as a critical mirror to seventeenth-century Leiden and Holland at large. It reveals that a policy of open citizenship, entrepreneurial liberty and peaceful and defensive alliances under a government of the rich who rotate offices without any single ruler such as a Stadholder, fosters commerce, learning and social stability, and hence the preservation and increase of the commonwealth.

This praise of Athens engenders a critique of the other classical polity most frequently heralded as a time-honoured source of inspiration and emulation: Ancient Rome. For the brothers De la Court, the Roman Republic, "utterly founded on the violence of arms to the ruin of all learning and commerce", is the ultimate antithesis of good republican rule. With its belligerent spirit and its distaste for trade, Rome, "that all murdering, plundering and the world destroying Republic, had to be an enemy of commerce" - as proved the case when Rome conquered the great trading republics of Athens and Carthage. ${ }^{51}$ Eventually, the absence of merchants and the excess of empire made Rome relapse into the tyranny of its own military commanders..$^{2}$

This disapproval of the example of Rome was a common theme in the early-modern Netherlands, going back as far as Erasmus's criticism of Roman expansionism. ${ }^{33}$ Boxhorn, for instance, paid considerable attention

49 Ibidem III.II.1, p. 590-591: “... een onderling verbond tot gemeene bescherminge ... een van de voorneemste oorsaaken der Atheniensen grootheid.” III.II.4, p. 624: “... want nietwes schadeliker voor een Staat, die op konst, koopman-en weetenschappen geboud is, bedagt kan werden, als de alles vernielende en commercie belettende Oorlog."

${ }^{50}$ Ibidem III.II.2, p. 615: “... boven maaten in alle weelde, konst, kennisse, en rijkdom is toegenoomen." III.II.4, p. 619, 621: “Onder een volkome Populaare Regeering zonder eenig Hoofd, of blijvende Raads- en Magistraats-persoonen ... Alle Weetenschappen en Konsten wierden hier zoodanig aangequeekt."

${ }^{51}$ Welvaren 9, p. 20: "Want die Roomsche Republijk t'eenemael op geweld van wapenen gefondeerd sijnde geweest tot ruine van alle geleerdheid, ende koopmanschappen ... die alles moordende, plonderende, en wereld verwoestende Republijck viandin der koopmanschappen moste sijn."

${ }^{5^{2}}$ See the extensive discussion of Roman history in Politike Weeg-schaal II.VI.2-4, and cf. Haitsma Mulier, Myth of Venice, 137-138.

53 See Martin van Gelderen, "The Low Countries," in Howel A. Lloyd et al. (eds.), European Political Thought 1450-1700. Religion, Law and Philosophy (New Haven and London: Yale University Press, 2007), 376-415, esp. 381. 
to the demise of the Roman Republic in his classes from the $1640 s,{ }^{54}$ while another Leiden academic, Antonius Thysius, similarly refuted belligerent Rome in an expansive overview of the history of various republics published in 1646.55 Yet the explicit way in which the De la Courts rebuke the Roman Republic is beyond compare. The aristocratic Roman Senate, so the brothers insist with numerous quotes from Lucan, Livy and Tacitus, was enslaved by "the passion and lust to wage war", which condemned the common citizenry to drudge under unbearable imposts and turned the city into "a deadly Pest for the earth". ${ }^{6}$ Indeed, the territorial expansionism of Rome destroyed all the other classical republics and thereby eradicated the ancient European legacy of liberty:

For not only Greece and all the Islands in the Mediterranean, but also all of Italy, France, and Spain and all of Germany was divided among incredibly many Republics, until that ... war-loving and all-destroying Roman Republic had subdued and destroyed them with her weapons, one by one..$^{57}$

By way of conclusion to this flamboyant condemnation of Rome, the brothers De la Court express their wonder "that this murderers' den, this wolfs nest, this most detestable and horrible Republic that has ever been on this earth, is praised so much by many"..$^{8}$ The implicit reference to Machiavelli's Discorsi must have been obvious to most contemporary readers, and it serves as a warning to modern historians not to overemphasize Machiavelli's influence on the De la Courts. ${ }^{59}$ Moreover, their

${ }^{54}$ Boxhorn, Emblemata politica. Accedunt dissertationes politicae de Romanorum Imperio (Amsterdam, 1651), esp. dissertation XIV: "De mutatione Reip. \& initiis Monarchiae Caesarum sive C. Julius Caesar," p. 310-327.

55 Antonius Thysius, Memorabilia celebriorum veterum rerumpublicarum (Leiden, 1646). Pieter de la Court van der Voort owned a copy of this treatise: Library, fol. 31. See also Haitsma Mulier, Myth of Venice, 59-6o.

${ }^{5}$ Politike Weeg-schaal II.VI.4, p. 507, 511: “... passie en geneegentheid tot oorlogen ... een doodelike Pest voor den aardbodem."

57 Ibidem I.III.1, p. 231: "Want niet alleen Griekenland en alle de Eylanden der Middelandse Zee, maar ook geheel Italien, Vrankrijk en Spanjen, jaa ook geheel Duitsland, in ongeloovelik veel Republiken verdeelt was; tot dat die (Non erat is populus quem pax tranquilla juvaret, quem sua libertas immotis pasceret armis. Lucanus) krijgs-lievende, en alles vernielende Roomse Republik alle de zelven, d'eene voor d'ander na, door hare wapenen hebbende doen bukken, en verwoest." The quote is from Lucan, Pharsalia I, vs. 171-172.

${ }^{5}$ Ibidem II.VI.4, p. 513: “... dat deeze moort-kuil, dit Wolve-nest, deeze verfoeyelikste en grouwelikste Republik, die ooit op den aardbodem is geweest, by veelen zeer werd gepreezen."

${ }_{59}$ Cf. Machiavelli, Discorsi, esp. I.6, II.3-4, II.19, II.30, III.24. See the analysis in David Armitage, The Ideological Origins of the British Empire (Cambridge: Cambridge University Press, 2000), 125-132; and Idem, "Empire and Liberty: A Republican Dilemma," in Van Gelderen and Skinner (eds.), Republicanism, vol. II: 29-46. 
harsh criticism of Rome's territorial expansion entails a crucial difference from many English republicans, including Streater, Nedham, and most importantly Harrington and Sidney, who praised the Roman Republic precisely for its glorious conquests. ${ }^{60}$ Where Machiavelli's beleaguered Florence or Cromwell's expanding England looked back to the military greatness of Rome, the commercial commonwealth of the brothers De la Court followed another model of republican splendour.

\section{A Commonwealth of Cats}

Unlike Rome, the republic of the De la Courts is not a commonwealth for the increase of territory, but for the increase of trade. The brothers' argument for such commercial expansionism relies on a seeming paradox: on the one hand, it proposes a non-offensive foreign policy, because commerce thrives in peace, on the other it propagates the establishment of a colonial empire of trading posts to foster global trade. Yet for the brothers De la Court peace and imperialism do not entail a contradiction in terms. Appropriating the experience of ancient Athens and the contemporary city-states of the Mediterranean, they maintain that a republic of trade should refrain from all territorial conquests and remain utterly self-reliant in order that overseas trade can expand without impediment.

This argument follows from several claims. First, the enduring independence of small cities like Lucca and Ragusa reveals that a good defence is the key for maintaining republican liberty. The De la Courts therefore insist repeatedly that the main duty of the magistrate of Leiden and the other towns of Holland is to arm the rich citizens and uphold strong protective fortifications against any external threat. ${ }^{61}$ Moreover, the demise of Rome and the commercial lustre of the contrary republican paradigm, Venice, show that mercantile republics should opt for defensive peace instead of offensive war. A similar claim had been brought forward before by the Venetian author Paolo Paruta, one of the main propagators of the Myth of Venice in the sixteenth century. In a clear repudiation of Machiavelli's celebration of Rome's military expansionism, Paruta argued that the Venetians "employed other means to defend

\footnotetext{
6o See Sidney, Court Maxims, 16-17; and Harrington, Oceana, 223-229. Cf. the discussion in Scott, Commonwealth Principles, 210-229; and Armitage, Ideological Origins, 134-141. See also Fergus Millar, The Roman Republic in Political Thought (Hanover: University Press of New England, 2002), 80-99.

${ }^{61}$ Welvaren 58-6o, elaborated further in Aanwysing I.1, II.15.
} 
liberty and to increase their riches, using for the former the navy, and for the latter traffic and merchandizing". Such commercial growth, Paruta continued, followed from the maxims of "preserving peace and keeping open and free commerce with all". ${ }^{62}$ The De la Courts adopt this Venetian example to the case of Holland in general and with regard to Leiden in particular, for Leiden, "living of the Academy and the Industries, is not founded on arms, but on peace". ${ }^{6}$

Leiden's reason of state must necessarily be pacifist since warfare obstructs international trade and requires large financial resources. Hence, "in Republics that live of commerce ... a Guerre offensive is always a Guerre consumtive" ${ }^{64}$ Offensive warfare is simply too costly for a precarious city like Leiden. With a metaphor that again implicitly refutes Machiavelli, De la Court concludes that a truly commercial commonwealth should not wrap itself up in a lion's skin or a fox's pelt, but rather follow the commendable example of another species:

a $\mathrm{Cat}$, who pays diligent attention to provide for food and takes great care to preserve its own young ones, and never barks or snarls at someone who provokes or abuses it ... When assaulted and pursued, it immediately flees into some hole or natural stronghold, where it remains silent until the emergency is over ... So that by these praiseworthy arts, the cats enjoy more quiet everywhere, live longer, are more pleasant and in much greater number than the devouring Beasts, Lions ... or cheating Foxes. ${ }^{65}$

In short, the best strategy to survive in the aggressive animal realm of international politics is to adopt the self-satisfied stoicism of cats.

${ }_{62}$ Paolo Paruta, Discorsi politici (Venice, 1599) II.1, p. 367, 385: “... si'impiegarono in altri studii, per difendere la libertà, \& accrescere le ricchezze loro, usando in quella cosa la militia del mare, \& in questa i trafichi, \& le mercantie ... il conservare la pace, \& tenere il commercio aperto, \& libero con tutti." Pieter de la Court van der Voort owned a copy of this work: Library, fol. 19. On Paruta, see Haitsma Mulier, Myth of Venice, 29-31; Viroli, From Politics to Reason of State, 231-237; and Comparato, "Republicanism in Italy," 170-172, $183-184$.

${ }^{63}$ Welvaren 58, p. 135: “... van het Akademij ende Manufacturen levende, is niet op de wapenen, maer op de vrede gefondeerd." This argument is extensively elaborated in Aanwysing II.2-4.

${ }^{64}$ Aanwysing II.4, p. 253: “... in Republiken die van de koopmanschap leeven ... is alle aangrijpende oorlog schaadelik, en Guerre offensive altijds Guerre consumtive."

${ }_{5}$ Ibidem, 254-255: "Voorwaar een Kat past vlytig op om sijnen kost te soeken, ende draagd groote sorg om sijne eigene jongen te bewaaren: bast nog smaald noit teegen iemand die hem tergd ofte lasterd ... Sulks hy aangeransd en vervolgd zijnde, terstond vlugt naar eenig gat ofte natuurelike sterkte, alwaar hy sig stille houd tot dat die nood over gaa ... sulks door deese roemwaardige kosnten, de katten overal veel meer rust genieten, langer leeven, alsmeede aangenaamer en in veel grooter getaale zijn, als de verslindende Dieren, Leewen ... ofte de bedriegende Vossen." Cf. Machiavelli, Principe XVIII. 
This imaginative plea for a peaceful, defensive and autarchic foreign policy involved a clear move in the debate on Dutch foreign policy in the wake of the Peace of Westphalia. In line with the claim of the Duke of Rohan that the interest of the United Provinces was to make war, ${ }^{66}$ many Dutch pamphleteers during the 1650 os and 1660 os favoured the resumption of the glorious earlier conquests of the Stadholder's troops against Spain. "War is an exercise of the highest justice", as one pamphleteer argued against the Peace treaty with England in $1654 .{ }^{67}$ Another pamphlet insisted in 1661 that the Dutch should follow the example of the Roman Republic and again take up arms against Spain to safeguard their commercial interests overseas: “if it isn't done for the reputation of our Country, let it then be done for the sake of profit." ${ }^{68}$ To counter such claims, the brothers De la Court asserted emphatically that the interest of Leiden and Holland as a whole could not possibly consist in war and conquests precisely because the general interest was based on international trade. Employing the language of a commercial reason of state, they thus substantiated the position of the Holland mercantile elite, which generally favoured peace and a strong navy over a costly land war and a standing army that was chiefly to be paid for by the province of Holland..$^{69}$

Yet there is a clear limit to the pacifism of the brothers De la Court, for their rejection of territorial conquests does not entail a rejection of colonial expansion..$^{70}$ In the reason of state tradition, the establishment of colonies was often characterized as a peaceful alternative to military conquests for achieving republican grandezza. Botero, in particular, stressed the utility of colonization as a profitable way to pursuit expansion without

${ }^{66}$ Rohan, De l'interest des princes, 124-125.

${ }_{7}$ Bedenckingen op de Deductie, 73: "Oorlogh is een exercitie van de hoogste justitie."

${ }^{68}$ Verthooninge, ghedaen aen die van de Vereenichde Nederlanden (s.l., 1661), sig. B: "so het niet geschiet uyt reputatie van ons Lant, laet het om profyts wille gedaen werden."

${ }_{69}$ On the foreign policy of the States of Holland vis-à-vis the other Dutch provinces, see J.C. Boogman, "Die holländische Tradition in der niederländischen Geschichte," in Boogman, Van spel en spelers (The Hague: Martinus Nijhoff, 1982), 147-161, and the more extensive discussion in J.L. Price, Holland and the Dutch Republic in the Seventeenth Century. The Politics of Particularism (Oxford: Clarendon Press, 1994). Cf. for the debates across the North Sea, Steven Pincus, Protestantism and Patriotism. Ideologies and the Making of English Foreign Policy, 1650-1668 (Cambridge: Cambridge University Press, 1996).

${ }^{70}$ On the development of Dutch colonial ideology in the seventeenth century, see Martine van Ittersum, Profit and Principle. Hugo Grotius, Natural Rights Theories and the Rise of Dutch Power in the East Indies (1595-1615) (Leiden and Boston: Brill, 2006); and my "Republican Empire. Colonialism, Commerce and Corruption in the Dutch Golden Age," Renaissance Studies 26 (2012). 
resorting to violence. ${ }^{11}$ The brothers De la Court readily adopted this commercial ideology of colonization. While "the Conquests of other Cities" might lead to "the demise of nearly all Free-States", they argued that there is also a positive form of expansion, namely "Conquests that improve Commerce ... like the Europeans obtained from the Indians" ${ }^{72}$ Elaborating on this claim, De la Court insisted that the settlement of overseas colonies should be a central policy of a commercial commonwealth like Holland. One of the characteristics of a republic based on immigration and trade, so De la Court argued, is a large number of unhappy and restless inhabitants. The capriciousness of commerce causes a continuous threat of instant poverty, and hence there will always be discontented people who prefer to try their luck elsewhere. Moreover, the constant rotation in government and the meritocracy typical of a true republic result in similar dissatisfaction among the sons of the establishment who are not elected to the ranks of the administration. They too will therefore long for another territory where they can give full rein to their ambition and where they will be honoured for their deeds. The powers in being should try to get rid of these young men who, driven by self-love, might easily endeavour to rebel against the government. With these arguments, De la Court tried to convince the Dutch political establishment of the necessity of erecting satellite states overseas, in which Dutch expatriates would enjoy new opportunities whilst remaining subject to the political supervision of the metropolis. To alleviate internal pressure and to pursue external greatness, a commercial commonwealth should follow the example of classical commercial republics like Athens and establish such a network of colonial trading posts that enhance commercial increase. ${ }^{73}$

At first sight, this mercantile colonialist ideology, which clearly intended to legitimize the seventeenth-century practice of Dutch overseas expansionism, might be characterized as a distinctly modern justification of colonization, typical to the rise of the imperialist state in the West. Nonetheless, it is important to stress that the logic behind the De la Courts' commercial imperialism remains largely within the classical

${ }^{71}$ Botero, Cause della grandezza delle città, 333-334. For the impact of Botero's argument for commercial colonization, see Andrew Fitzmaurice, "The Ideology of Early Modern Colonisation," History Compass 2 (2004), 1-14.

${ }^{72}$ Politike Discoursen II.V.6, p. 121: “... de Conquesten van andere Steeden, buiten haare Republijk te doen, dat is kennelijk de ondergang van meest alle Vrye-Staaten ... Maar aangaande Conquesten die de Koopmanschap verbeteren, en doen bloejen, gelijk die van Europa op de Indiaanen gedaan hebben, die zijn goed."

${ }^{73}$ Aanwysing I.26. 
framework of the single metropolis and its dependent colonies. Their model of a colonizing republic is not the territorial state of the Dutch Republic at large, but the independent, self-contained city of Leiden and by extrapolation the amalgam of cities that constituted the States of Holland. De la Court categorically stressed that each city in Holland could easily subsist independently, and that Holland at large, "observing its own Interest, could establish here in Europe $a$ State without depending on any other". ${ }^{74}$ While arguing for overseas colonization, De la Court fervently spurned a closer union of the United Provinces beyond a mere alliance for mutual defence. This rejection of federalisation even entailed the radical proposal of digging a large trench to separate Holland once and for all from the other provinces and hence turn it into an isle of splendid isolation. ${ }^{75}$

Like their assessment of the Roman expansionist model, this particularist core of the republican politics of the brothers De la Court involves a crucial distinction of contemporary English republicanism. In spite of their widespread admiration of Dutch prosperity, English republicans generally maintained that the Dutch Republic suffered from one fundamental shortcoming: its lack of a strong centralized government. Milton, for example, asserted with characteristic bravura that the English Commonwealth would "far exceed the United Provinces by having, not as they ... many Sovranties united in one Commonwealth, but many Commonwealths under one united and entrusted Sovrantie". ${ }^{76} \mathrm{~A}$ few years later Sidney similarly rejected the Dutch model by arguing that "their constitutions seem to have a more particular regard to the preservation of the liberties and privileges of each town and province than to the welfare of the whole ... Their commonwealth seems to be a vast building of loose stones, which not well cemented, threatens ruin". ${ }^{77}$ In clear contrast, the fragmentation of the Dutch Republic was no issue at all for the De la Courts, whose republican model, unlike Milton's or Sidney's, continued to focus on the self-contained city instead of the centralized national state.

\footnotetext{
${ }^{74}$ Ibidem II.11, p. 311: “... dat Holland sijn eigen Interest wel waarneemende, hier in Europen een Staat op sig selven soude konnen maaken, sonder van eenig ander te dependeeren."

75 Ibidem II.14. Following the judgment of Pieter de Groot, who called it a "dubious" argument, this proposal had not been included in the Interest van Holland. See Pieter de Groot to Johan de Witt, 2 June 1662, in Brieven aan Johan de Witt, ed. Japikse, vol. II: 108.

${ }^{7^{6}}$ Milton, The Readie and Easie Way to Establish a Free Commonwealth, in Idem, Areopagitica and Other Political Writings, 443.

77 Sidney, Court Maxims, 172-173.
} 
A revealing passage in the Politike Weeg-schaal stresses the advantage of such an urban republic which, precisely because it is confined to the limits of a single city, must practice a peaceful foreign policy that promotes trade. When rewriting this passage De la Court added a short side note to the effect that republics can very well consist of a federation of different cities, hastily referring the reader to the source of this claim: "All of which has been very well demonstrated in detail by J. Harrington in his Commonwealth of Oceana. So it is unnecessary to talk about it further." ${ }^{78}$

This manuscript reference to Harrington - the sole mention of any English republican in the entire œuvre of the brothers De la Court - is particularly significant because it shows how De la Court appropriated an argument wholly secondary to Harrington's thought for his own Dutch republican agenda. ${ }^{79}$ Ironically, this appropriation thus reveals how little the English republican experience of the 1650 s could offer to the fragmented federation of cities and provinces across the North Sea. Clearly, the role model for the De la Courts, as for all their republican compatriots, was not the centralized, expansionist monarchical republic of England but the self-contained city-states of the classical and the contemporary Mediterranean, the colonizing, commercial cities of Athens and Venice. Just like these shining examples of haughty and stoic self-rule, the republic of the brothers De la Court proudly maintained its distance from the hectic pursuits of the centralized state: it was, after all, a commonwealth of cats.

\section{The Politics of Free Trade}

\section{Liberty as the Highest Law}

Leiden's prospects, modelled on Ancient Athens, form the inductive foundation of a general theory of commercial reason of state that the brothers De la Court apply to the case of Holland at large. The core of this

${ }^{78}$ Amsterdam University Library, Ms. XXV C41, addition to Politike Weeg-schaal III.I.6, p. 577: “... twelk alle in 't bysonder seer wel is aangeweesen door J. Harrington in syn Commonwealth of Oceana. Sulks onnodig is hiervan breeder te spreeken." De la Court probably refers to the passage in Harrington, Oceana, 163 . The date of this addition remains unknown, but it must have been made after 1662. The first and only evidence that De la Court knew Harrington is his letter of New Year's Eve 1672.

${ }^{79}$ For two lucid analyses of the main characteristics of Harrington's republicanism, see Jonathan Scott, "The Rapture of Motion: James Harrington's Republicanism," in Nicholas Phillipson and Quentin Skinner (eds.), Political Discourse in Early Modern Britain (Cambridge: Cambridge University Press, 1993), 139-163; and Blair Worden, "James Harrington and 'The Commonwealth of Oceana,' 1656," in Wootton (ed.), Republicanism, 82-110. 
theory lies in the Ciceronian maxim salus populi suprema lex, a powerful and widespread early-modern commonplace that, like the connected adage 'necessity has no law', could be mobilized for various political purposes, both monarchical and republican. ${ }^{80}$ The De la Courts comment on this diverse usage of the axiom by contending that the phrase is like "a nice doll praised by all outwardly, but by only a few valued and cared for inwardly". ${ }^{81}$ For the brothers, the true significance of the maxim is revealed by the case of Leiden, which shows that the health of the people in a mercantile republic consists of two intrinsically connected elements: the greatness of the commonwealth and the advancement of liberty. Since a republic of trade should forsake territorial conquests, commerce itself must be the means to achieve the preservation and increase of the polity, and commerce, as the example of Athens demonstrates, thrives in liberty. Hence, freedom of trade, which includes freedom of immigration, occupation and enterprise, is the supreme law that leads to commercial greatness.

This fundamental claim that free trade forms the essence of commercial reason of state is based on several premises. The argument of the De la Courts starts with the assertion that human natural liberty should be maintained as much as possible within the boundaries of the law in order to promote common prosperity and the growth of society. As the brothers boldly assert, "all Political thinkers generally admit that the highest perfection of Politics and human society consists in this single point, namely, that the Subjects are left as much natural liberty as is in any way doable". ${ }^{82}$ A commonwealth where all inhabitants enjoy such liberty will improve its competitiveness with the surrounding polities and therefore fulfil its chief goal, the increase of its population. Indeed, a city like Leiden "will only be able to subsist by giving its inhabitants much more freedom than they can find in any nearby or better situated Cities or places". ${ }^{83}$ The De la

${ }^{80}$ Cf. Miller, Defining the Common Good, 39-40.

${ }^{81}$ Welvaren 61, p. 141: "Salus populi Suprema Lex ... waerelijck het is een schoone pop bij allen uijterlijck gepreesen, bij weinigen innerlijck besorght ofte geaght."

${ }_{82}$ Ibidem 3, p. 10: "Want alle Politijcken bekennen in het generael, dat de hooghste volmaecktheid der Politie ende menschelijcke societeijt bestaet in dit eenige point, namentlijk Dat den Onderdanen werde gelaten soo groote naturelijcke vrijheid als eenighsins doenlijck is." See the similar passage in Politike Discoursen I.I.1, p. 21. Cf. Hobbes, Elements of Law II.9, p. 178: "That to leave man as much liberty as may be, without hurt of the public, and to ordain means for trade and labour, and to forbid superfluous expenses, is a duty of a sovereign by the law of nature."

${ }_{3}$ Welvaren 80, p. 171: “... gansch niet subsisteeren kan, dan met den inwoonderen veel meer vrijheid te geeven, als sij in eenige nabij, of beeter geleegene Steden, ofte plaetsen konnen beleeven." 
Courts therefore stress the need to grant all immigrants citizenship rights and the same opportunities to make a living as the indigenous population, for "absolute uniform freedom for all inhabitants, bearing uniform burdens" is apart from a natural right a "powerful means to attract foreigners" ${ }^{84}$

Such freedom of immigration and occupation is all the more important since immigrants will also bring "knowledge and goods" from outside. Newcomers do not own any fixed property and therefore they will have to invest their foreign experience and capital "to invent and create new fisheries, manufactures, trade, and navigations". Hence, a constant influx of immigrants will guarantee the constant renewal and improvement of trade and industry. ${ }^{85}$ Commercial increase and liberty are thus mutually dependent:

Trade is a very powerful means to employ and feed many people. ... Yet Trade is not fixed to one place only. Where Merchants are burdened least and where they are given more freedom to make and keep profits, there they will remain. But where, on the contrary, the freedom to make profits is restricted, or where the rich Merchants are harshly charged, there they are chased away or extinguished. ${ }^{86}$

In short, in an emerging era of international commercial competition, a commercial commonwealth like Leiden or Holland at large can only endure by conceding all inhabitants a range of liberties: "freedom in Religion, Study, trade, manufactures, arts, citizenship and Government" ${ }^{87}$

In the course of the later seventeenth century, at the threshold of modernity, this idea that commercial success is the key to compete with other polities became an important element of political thinking all over Europe. Istvan Hont has analyzed this intellectual development in considerable detail, convincingly arguing that such 'jealousy of trade' "was an

${ }^{84}$ Ibidem 2, p. 8: “... hoe kraghtigen middel om vremde inwoonders aentelokken ... de absolute eenparige vrijheid voor alle inwoonders, eenparige lasten dragende, intevoeren."

${ }^{85}$ Aanwysing I.15, p. 69: “... alle haare kennise en goederen te besteeden, om nieuwe visserien, handwerken, koopmanschap, ende navigatien te bedenken, en te formeeren.”

${ }^{86}$ Politike Discoursen I.I.1, p. 4: “... dat de koopmanschap een zeer kragtig middel is, om zeer veele menschen besig te houden ende te voeden ... Maar de Koopmanschap is aan geen plaats vast, daarmen den Koopluiden minst beswaard, en meer vryheids geeft om haare profiten te mogen doen, ende te conserveeren, daar heeftmense: ende daarmen ter contrarie de vryheid om winsten te doen besnoeit, ofte de rijke Koopluiden hard taxeert, daar verjaagd of blustmense uit."

${ }^{87}$ Welvaren 8o, p. 171: “... door vrijheid in Religien, Studien, koopmanschappen, manufacturen, konsten, borgerschap en Regeeringh.” 
extrapolation of Machiavellianism to the modern trading economy", and "the application of reason of state to international trade". ${ }^{88}$ Yet surprisingly, Hont has paid very little attention to Dutch theorizing about such commercial reason of state, although the Netherlands were the principal object of much of the jealousy in question. ${ }^{89}$ To mention just one example, Josiah Child stressed in 1668 that the "prodigious increase of the Netherlands in their domestick and foreign Trade, Riches, and multitude of Shipping, is the envy of the present, and may be the wonder of all future Generations". ${ }^{\circ}$ This assumption was shared by the Dutch themselves, such as a pamphleteer who argued in 1661 that Dutch primacy in world trade had caused that "several Nations have become jealous, especially the English, who cannot bear the prosperity of the Dutch"..$^{11}$

The brothers De la Court similarly realized that Holland's commercial success lead to the envy of other polities: even though "all Republics that are founded on peace and commerce share the same Interest with Holland", they would still try to obstruct "our main design, namely the increase of commerce"..$^{2}$ Therefore, all competitors, and in particular England, should be outplayed by a policy of insuperable freedom of trade. Drawing such a connection between liberty and commerce was, of course, hardly exceptional in the mercantile world on either side of the North Sea. Already in 1568, at the start of the Dutch Revolt, a pamphlet explicitly stressed that "Marchandise, Manufacture et Negotiations" should be seen as the sisters of "Liberté". ${ }^{3}$ The issue of free trade continued to dominate much of the political and economic debate - and warfare - between England and the Dutch Republic throughout the seventeenth century,

\footnotetext{
${ }^{88}$ Istvan Hont, Jealousy of Trade. International Competition and the Nation-State in Historical Perspective (Cambridge, Mass.: Harvard University Press, 2005), 9, 13.

${ }^{89}$ Hont only discusses the famous views of William Temple, the English ambassador to The Hague in the 166os: Ibidem, 194-201. More on the Dutch context can be found in Gijs Rommelse, The Second Anglo-Dutch War (1665-1667). International Raison d'État, Mercantilism, and Maritime Strife (Hilversum: Verloren, 2006).

${ }^{90}$ Josiah Child, Brief Observations Concerning Trade, and Interest of Money (London, 1668), 3, reprinted in Idem, A New Discourse of Trade (London, 1693).

${ }^{91}$ Verthooninge, ghedaen aen die van de Vereenichde Nederlanden, sig. A2: “... dat verscheyde Natien daer over jaloers sijn geworden en boven alle de Engelse, dewelcke niet kan verdragen de prosperiteyt van de Nederlanders."

${ }^{92}$ Aanwysing II.6, p. $275^{-276: ~ “ . . . ~ d a t ~ a l l e ~ R e p u b l i k e n, ~ o p ~ v r e e d e ~ e n ~ k o o p m a n s c h a p ~}$ gefondeerd zijnde, het selve Interest met Holland hebben ... ons in ons voornaemste dessein, namentlik het vermeerderen der koopmanschap, altijds naar haar vermoogen sullen dwersdrijven."

${ }_{93}$ Quoted in Martin van Gelderen, "De Nederlandse Opstand (1555-1610): van 'vrijheden' naar 'oude vrijheid' en de 'vrijheid der conscientien'," in Haitsma Mulier and Velema (eds.), Vrijheid, 27-52: 31.
} 
from Grotius's famous treatise Mare liberum and its repudiation by John Selden ${ }^{94}$ to the writings of Dutch-English merchants like Gerard de Malynes and Edward Misselden..$^{95}$ In particular from the 1640 s and 1650 s onwards, many English pamphleteers expressed their envious admiration of the mercantile model of the Dutch, who, as the merchant Henry Robinson proclaimed, "may be thought one of the happiest [peoples] throughout the knowne world" since they "finde the advancing of Trade to be the onely true State Interest and Policy". ${ }^{96}$ By the early 166os, the claim that "a happy continuation of Commerce requires freedom" had become all but commonplace among the propagators of Dutch commerce vis-à-vis such English jealousy of trade. ${ }^{97}$

The argument for free trade of the brothers De la Court is clearly rooted in this Anglo-Dutch commercial and intellectual exchange ${ }^{98}$ Their contribution to the debate on Dutch commerce is particularly significant because of the comprehensiveness of their claim what exactly commercial liberty entails. Merging a Grotian notion of free property with mercantile reason of state, the thought of the De la Courts amounts to an extensive discussion of several concrete policy measures to promote free trade and thus enhance Holland's commercial greatness..$^{99}$

${ }^{94}$ On the debate between Grotius and Selden, see Mónica Brito Viera, "Mare Liberum vs. Mare Clausum: Grotius, Freitas, and Selden's Debate on Dominion Over the Seas," Journal of the History of Ideas 64 (2003), 361-377. Cf. also the different interpretations of Richard Tuck, "Grotius and Selden," in Burns and Goldie (eds.), Cambridge History of Political Thought, 499-529; and Sommerville, "Selden, Grotius, and the SeventeenthCentury Intellectual Revolution."

95 See Andrea Finkelstein, Harmony and the Balance. An Intellectual History of Seventeenth-Century English Economic Thought (Ann Arbor: University of Michigan Press, 2000), esp. 26-73.

${ }^{96}$ Henry Robinson, Certain Proposals in Order To the Peoples Freedome and Accommodation (London, 1652), 10. For other examples, see e.g. Parker, Of a Free Trade, 14; and Samuel Lambe, Seasonable Observations (s.l., [1658]), 7-8. Cf. Pincus, "Neither Machiavellian Moment nor Possessive Individualism," 719-720, and the extensive analysis in Joyce Appleby, Economic Thought and Ideology in Seventeenth-Century England (Princeton: Princeton University Press, 1978), 73-98.

${ }_{97}$ Speculatien over den innerlijcken toestant van regeringe in de Vereenigde Provintien (Heusden, 1660), 7: “... een geluckige voortganck van den Koophandel vereyschet vryheyt."

${ }_{98}$ Cf. the references in Aanwysing I.6 and I.9 to Gerard de Malynes, Consuetudo vel Lex Mercatoria, or the Ancient Law-Merchant (Londen, 1622). On the importance of merchant manuals such as the Lex Mercatoria, see Jochen Hoock, "Professional Ethics and Commercial Rationality at the Beginning of the Modern Era," in Jacob and Secretan (eds.), Self-Perception of Early Modern Capitalists, 147-159.

99 For a lucid analysis of seventeenth-century Dutch views on free trade, see HansJürgen Wagener, "Free Seas, Free Trade, Free People: Early Dutch Institutionalism," History of Political Economy 26, 3 (1994), 395-422. For the period following the De la Courts, see Ida 
This discussion forms the core of De la Court's reworking of the manuscript on Leiden's welfare to the Interest van Holland and the Aanwysing. De la Court maintains that like Leiden, Holland is plagued by numerous natural burdens, not only the "for people unhealthy weather" but especially the small size and scarcity of the country's soil. As a result, Holland's population "should by all means search its food abroad and continuously attract new Inhabitants from foreign Countries" ${ }^{100}$ Commerce and immigration are necessary for survival, and here Holland has an obvious advantage, for it is "very well situated to procure its food from the Sea, which is common to all" - the allusion to Grotius is implicit but clear. ${ }^{101}$ This favourable maritime position has led to the growth of Dutch fishery, soon followed by trade, industry, and seafaring, all essential sources of welfare. De la Court asserts self-assuredly that "in Europe no Country is more capable for Trade than Holland". In spite of war, international competition and jealousy of trade, "the Hollanders have navigated almost all Nations out of the great Ocean, the Mediterranean, the Indian Ocean, and the Baltic". ${ }^{102}$

For De la Court, the continuation of this commercial success depended on a range of liberties that would lure foreigners to Holland and promote the growth of trade. Apart from the freedom of immigration and occupation, these liberties include the freedom of enterprise and the freedom from taxation. Following the plea for entrepreneurial liberty against the control and levies of the halls in Leiden, De la Court contended that commercial enterprise in Holland at large should not be obstructed by the imposition of too heavy a tax burden. ${ }^{103}$ In his treatise on the grandezza of cities, Botero already argued that the towns of the Netherlands were "the most mercantile" because of "the frankness of taxes", which made that "the merchandise that entered there and left (and entered and left infi-

Nijenhuis, "De ontwikkeling van het politiek-economische vrijheidsbegrip in de Republiek," in Haitsma Mulier and Velema (eds.), Vrijheid, 233-252; and Karel Davids, "From De la Court to Vreede. Regulation and Self-Regulation in Dutch Economic Discourse from c. 1660 to the Napoleonic Era," The Journal of European Economic History 30, 2 (2001), $245^{-289}$.

${ }_{100}$ Aanwysing I.3-5, p. 21, 27: “... voor den menschen ongesond weeder ... dat het in allen manieren sijn voedsel buiten 's Lands moet soeken, ende geduurig niewe Ingesetenen uit vreemde Landen tot zig trekken moet."

${ }^{101}$ Ibidem I.6, p. 27: "En om sijn voedsel uit der Zee, die een ieder gemeen is, te haalen; legd Holland seer wel."

${ }_{102}$ Ibidem I.7, p. 31: "In Europa is geen Land tot de Negotie bequaamer als Holland." Ibidem I.13, p. 58: “... dat de Hollanders by naast alle Natien, soo uit den grooten Oceaan, Middelandse, Indise, als Belt-Zee, gevaaren hebbende."

${ }^{103}$ Cf. Welvaren 44 with Aanwysing I.17, 20-21. 
nitely) paid almost nothing". ${ }^{104}$ De la Court adopted this assertion, claiming that by the 1660 s Holland had deviated from this admirable policy. Although the "Freedom of Fishery and Trade is still greater than elsewhere", he argued, the tax burden was far too heavy. De la Court forcefully maintained that taxes "have risen now that high, that the like has never been seen or heard of in any Republic in the World, much less in a Country only subsisting of commerce". ${ }^{105}$ This assertion involved only a little hyperbole, for per capita taxation in seventeenth-century Holland was indeed considerably higher than in other countries. ${ }^{106}$ Facing this reality, De la Court insisted that such "heavy and numerous imposts" threatened to divert Holland's commerce and would thus "eventually chase away the Country's welfare". ${ }^{107}$

This argument for free enterprise and moderate taxation is loosely based on a conventional defence of undiluted property rights. Echoing Grotius' discussion of the creation of individual property, the De la Courts stress "that man is by nature the master and appreciator of his own goods and labour ... for nature gives him privately the judgement over his property". ${ }^{108}$ In other words, private ownership is a natural right that predates the establishment of the commonwealth. This claim involves an explicit repudiation of the classical arguments in Plato and Thomas More's Utopia for the collectivisation of property, which De la Court classifies as "so alien to human nature". ${ }^{109}$ In his mercantile logic, collective property can only

${ }^{104}$ Botero, Cause della grandezza delle città, 343-4: "Le Città di Fiandra sono state le più mercantili, e le più frequentate Città d'Europa: Se tu ne ricercherai la cagione, troverai essere stata tra l'altra, la franchezza dalle gabelle: perché la mercantia, che vi entrava, e n' usciva, (e ve ne' entrava, e n' usciva infinita) non pagava quasi nulla."

${ }^{105}$ Aanwysing I.19-21, p. 84, 91: "De Vryheid van Visseryen en Negotie aangaande is nog grooter als ergens'; ‘... soo hoog gereesen, dat nooit diergelijke in eenige Republijke ter Weereld, veel min in eenen Lande op koopmanschap, en nergens anders op bestaande, is gehoord of gesien geweest."

${ }^{106}$ See the comparison in Jan Luiten van Zanden and Maarten Prak, "Towards an Economic Interpretation of Citizenship: The Dutch Republic Between Medieval Communes and Modern Nation-States," European Review of Economic History 10 (2006), 111-145: 130.

${ }^{107}$ Aanwysing I.21, p. 90: "Dat de swaare ende eenigvuldige imposten, 's Lands welvaaren endelik sullen verjaagen."

${ }_{108}$ Politike Discoursen I.I.5, p. 54: “... dat de mensch van nature meester en waardeerder van sijn eigen goed en arbeid zijnde, dien-volgende vermag daar meede te leeven, en 't selven soo hoog te agten, als hy wil, sulks de natuur hem privativelik het oordeel over het sijnen geeft." Cf. Grotius, Rights of War and Peace II.II.2, p. 78-80, and see the analysis in Stephen Buckle, Natural Law and the Theory of Property. Grotius to Hume (Oxford: Clarendon Press, 1991), 10-14, 35-44.

${ }^{109}$ Sinryke Fabulen, 534: “... soo vremd van der menscheliker aard.” See Plato, Republic, 416d-417b, 462b-c, and Thomas More, Utopia, trans. Clarence H. Miller (New Haven and 
be established by civil law, but it is utterly unthinkable that a law that collectivises property could arise out of general consent:

We are humans by nature, and only by coincidence are we members of a Society or Republic, so we should have property before the law could make it collective. It is therefore not easily understood how the diligent and thrifty could have been moved to share their own riches voluntarily with the poverty of the lazy and the wasteful People. ${ }^{10}$

It is claims like these that put the De la Courts squarely outside of the 'Greek republican tradition', which according to Eric Nelson championed the redistribution of wealth and collective property from Plato to the American Revolution. ${ }^{11}$ The republican model of the De la Courts is clearly a Greek model, but instead of the philospher's republic of Plato, their model is the merchant's republic of Ancient Athens.

In such a commercial commonwealth, the taxation of private property can only be justified if it enhances the general interest of the state, for "without taxes, a State cannot be protected". ${ }^{12}$ De la Court concludes that Holland's commercial reason of state requires a protectionist policy of taxation that "burdens least the means of subsistence which matters us most, which we lose the soonest and which, once lost, we cannot easily recover". ${ }^{13}$ The pillars of Holland's economy, the fishermen, artisans, and especially the international merchants, should therefore be exempted from taxation. "Bringing profit from abroad into the Country, they are very necessary for the State, yet they can, because of their commerce and correspondence, divert themselves, their goods, and their arts very easily into other Countries."114 Facing international competition, Holland should

London: Yale University Press, 2001), 46-48. Pieter de la Court van der Voort owned two editions of Plato's Opera omnia (one with the commentary of Marsilio Ficino), a French edition of La République (Paris, 160o), and the Amsterdam 1631 edition of Respublica Th. Mori Eutopiae. See Library, fols. 10, 11, 31.

${ }^{11}$ Sinryke Fabulen, 535: “... dat wy uit der aard menschen, ende niet dan by toevalle leeden eener Maatschappie ofte Republike zijn; sulks wy ook eer goederen souden hebben, eer de wet soude konnen de selve gemeen maken; soo is niet wel te begrijpen, dat de naarstige en spaarsaame souden konnen werden bewoogen haaren eigen rijkdom, met de arremoede der leuje ende quistige Menschen vrywillig gemeen te maken."

11 See Nelson, Greek Tradition.

${ }^{112}$ Politike Discoursen I.I.1, p. 18: "Sonder lasten, is een Staat niet te beschermen."

${ }^{113}$ Aanwysing I.24, p. 115: “... dat men nogtans minst beswaren mag dat middel van subsistentie waar an ons meest gelegen is, en welk wy allerligst verliesen, en verloren zijnde niet ligtelik wederom bekomen."

${ }^{114}$ Politike Discoursen I.I.1, p. 19: “ ... want alle deesen van buiten winst in 't Land brengende, zeer noodsaakelik voor den Staat zijnde, nogtans zeer gemakkelik door haare correspondentie ende koopmanschap, haare personen, goederen en konsten in andere Landen konnen brengen." 
favour those who make profits abroad: the entire community depends on their wealth, and if they would be taxed excessively they would leave the country. Accordingly, the manufacturing of goods should not be taxed, nor should any tariffs be raised on the export of these goods or on the import of raw materials needed for the industry. Yet taxation of consumption and landed property is an easy and necessary means to secure the state's revenue, and foreign goods that compete with Holland's trade and industry are to be levied as much as possible. International trade is a zerosum game, and Holland must take it all. ${ }^{15}$

\section{Circumventing Monopoly}

This combined argument for free enterprise within the commonwealth and a protectionist policy vis-à-vis foreign competitors amounts to the further claim that chartered monopolies in international trade, such as the Dutch East India Company (VOC), go against true commercial reason of state. This claim is still absent from the De la Courts' discussion of Leiden's welfare, but it takes centre stage in the Interest van Holland and the Aanwysing, reflecting a significant development in the brothers' economic thought. While their treatise on Leiden focused on unrestricted entrepreneurial freedom in the domestic sphere of an urban economy, from the start of the 166os De la Court's concerns gradually moved from domestic industry towards global trade. This results in a more regulative approach that emphasizes protectionist economic legislation "e mercaturae bono, more to the Interest of Merchants" in order to promote Holland's trade in the expanding arena of international competition overseas. ${ }^{116}$

Arguably, this change of emphasis from a domestic to a global economy is related to De la Court's growing involvement in international commerce and state policy in the wake of his marriage to Catharina Van der Voort in 1661. The relationship with the Van der Voorts significantly expanded De la Court's mercantile horizons, particularly after he left his native Leiden to settle with his family-in-law in Amsterdam in 1665. There, at the centre of global commerce, De la Court developed his business further in close collaboration with the successful firm of his family-in-law. Towards the end of the decade, he travelled as an agent for the Van der

\footnotetext{
${ }^{115}$ See Ibidem I.II.29-30, and the more regulative elaboration in Aanwysing I.21-24. Cf. also the mercantilist 'speculations' by De la Court's brother-in-law Van der Voort, published as appendix I in Kernkamp (ed.), "Brieven (1667-1685)," 90-95.

${ }^{116}$ Aanwysing II.15, p. 382: “... e mercaturae bono, meer naar het Interest der Koopluiden."
} 
Voorts to London and Italy. ${ }^{117}$ Eventually his trading network reached as far as the Caribbean, where his cousin Nicolaas, based in the Dutch settlement on Curaçao, worked on behalf of his family. ${ }^{118}$ The bond with the Van der Voorts also brought De la Court closer to Holland's political establishment. In the course of the Second Anglo-Dutch war, the firm of the Van der Voorts became directly involved in governmental policy by delivering over 900.000 guilders worth of artillery and provisions for the States of Holland and the Dutch fleet. ${ }^{119}$ This lucrative deal was mediated by Johan de Wit, a namesake and cousin of Holland's Grand Pensionary, who was also related to the Van derVoorts. As a representative of the States-General, De Wit kept the Amsterdam merchants informed of the latest news from The Hague and the operations of the fleet. ${ }^{120}$ This growing connection to the establishment in The Hague was ultimately sealed in 1670 when De la Court and his brother-in-law Guglielmo obtained a doctorate in law at the University of Orléans, a formality required to become a lawyer of the Court of Holland for which both took the oath in February $1671 .^{121}$

De la Court's increasing experience in international trade and government affairs is reflected in his forceful repudiation of the widely shared conviction that colonial trade in the East and West Indies should be regulated by chartered companies like the VOC. Both in the Dutch Republic and beyond, for example in Henry Parker's 1647 treatise Of a Free Trade, numerous mercantile theorists argued that the commercial interests of a state could best be served by establishing such companies to administer overseas trade. ${ }^{122}$ This was the dominant view, yet there were also a few dissonant voices. In the 1630 s and 1640 , a couple of Dutch pamphleteers and private merchants strongly advocated free trade in Dutch Brazil. ${ }^{123}$

${ }^{117}$ See RAL, FA De la Court, inv. nr. 8: The "Libro de Belanci" (1657-1670) of the brothers Van der Voort, which refers on fols. 20-22 to De la Court's stay in Messina, Naples and London in December 1669 .

${ }^{118}$ See the letters of Nicolaas de la Court to Pieter de la Court from $1672-1673$ in Kernkamp (ed.), "Brieven (1667-1685)," 51-63. On De la Court's commercial activities later in his life, see also the documents concerning his inheritance, dated 19 May 1691, in RAL, FA De la Court, inv. nr. 17 .

${ }^{19}$ The relevant documents are published as appendices IIa and IIb in Kernkamp (ed.), "Brieven (1667-1685)," 95-136.

${ }^{120}$ See Stadsarchief Amsterdam, Family Archive Backer, inv. nr. 465: letters from Johan de Wit to the brothers Van der Voort (1667-1671), and inv. nr. 466: undated documents on international affairs addressed to Giovanni Van der Voort.

${ }^{121}$ Kernkamp (ed.), "Brieven (1667-1683)," 43, note 2; and Frijhoff, "Reisjournaal," 17-18, note 19 .

${ }^{122}$ Parker, Ofa Free Trade.

${ }^{123}$ See e.g. Vertoogh by een lief-hebber des vaderlants vertoont. Teghen het ongefondeerde ende schadelijck sluyten der vryen handel in Brazil (s.l., 1637); Deductie, waer by 
In England, the Leveller and merchant William Walwyn denounced in his $165^{2}$ Conceptions for a Free Trade "the restriction and Government of Forraine Trade by Companyes", arguing that chartered monopolies conflict with the "Native Right" of merchants and the "publique good" of society. ${ }^{124}$ The Portuguese ambassador to Paris, Manuel Fernandez de Villareal, had a similar view. In his Le politique tres-chrestien ou discours politiques, a eulogy of Cardinal Richelieu published in 1645 by Elzevier in Leiden, he maintained that trading companies will only search for their own interest without regard for the common good. Fernandez de Villareal insisted that the establishment of such companies would therefore "oblige everyone to live in the disorders of avarice and not in the freedom of abundance". Tellingly, he mentioned the Dutch chartered companies as the prime example of this gruesome fate. ${ }^{125}$

As one of the most outspoken critics in the Dutch Republic itself, De la Court developped this condemnation of chartered companies further with the claim that freedom of trade should also entail free competition on the colonial market, and hence the abolition of the monopoly of trading companies like the VOC. The roots of this claim lie in the strong condemnation of the economic monopolisation by Leiden's guilds. Like guilds, De la Court insists, the Dutch trading companies curtail the "free trade of the common inhabitants" and "their natural liberty of seeking a livelihood in their fatherland".${ }^{126}$ Moreover, facing a globalizing economy and growing international rivalry, it is necessary that all Holland's merchants are able to trade with the vast territories outside of Europe so that commerce and foreign consumption can continue to increase. In line with Walwyn and Fernandez de Villareal, De la Court insists that these opportunities for worldwide commerce are discarded because the private interests of the trading companies necessarily conflict with the public

onpartijdelijck over-wogen ende bewesen wort, wat het beste voor de Compagnie van WestIndien zy: de handel te sluyten of open te laten (The Hague, 1638); Consideratien als dat de negotie op Brasil behoort open gestalt te worden (s.l., 1638); Consideratie over de tegenwoordige ghelegentheydt van Brasil (Amsterdam, 1644).

${ }_{124}$ "W Walwins Conceptions; For a Free Trade," in The Writings of William Walwyn, ed. Jack R. McMichael and Barbara Taft (Athens and London: University of Georgia Press, 1989), 446-452.

${ }_{125}$ [Manuel Fernandez de Villareal], Le politique tres-chrestien ou discours politiques ('Paris' [Leiden], 1645), 146: "C'est obliger tout le monde à vivre dans les desordres de l'avarice, \& non dans la liberté de l'abondance." Pieter de la Court van der Voort owned a copy of this treatise: see Library, fol. 19 .

${ }_{126}$ Aanwysing I.7, p. 32: “... vrijen handel der gemeene Ingeseetenen.” Ibidem I.16, p. 71: "... haare naturelike vryheid van 's leevens middelen in haar vaderland soekende, te besnoejen met geoctroyeerde ofte geslootene Compagnien en Gildens." 
interest of society at large. Whereas the general welfare lies in the increase of industry and trade, the "true Interest of such companies consists in seeking the most benefit for its common Participants ... and, in short, in making the most profits with the least trade and navigation". ${ }^{127}$ Their monopolistic position means that trading companies are not encouraged to open up new markets. "Certain profits make them stupid and slow", as De la Court asserts repeatedly. Trade will only prosper when there is competition, "for necessity makes an old wife trot, hunger makes raw beans sweet, and poverty begets ingenuity". ${ }^{128}$ De la Court imaginatively summarizes his criticism with the claim that the establishment of chartered monopolies attests to the same stupidity as Aesop's cat who, while licking the oil of a file, does not realize that he drills through his tongue and ends up sucking his own blood. ${ }^{129}$

This criticism of the Dutch trading companies was not confined to pure theory. In the summer of 1664, De la Court and his brothers-in-law asked the States-General for permission to search for a northern passage towards China along the shores of Siberia, thus circumventing the monopoly on Asian trade enjoyed by the VOC. Assisted in The Hague by their relative and informant Johan de Wit and by the jurist and anti-Stadholder publicist Johan Uytenhage de Mist, De la Court and the Van der Voorts thus endeavoured to challenge the vested colonial interests. ${ }^{130}$ A first request was turned down by the States-General after it heard the objections of the directors of the VOC. Yet De la Court cum suis did not give in and they sent a subsequent request to the States of Holland. Following De la Court's argumentation in the Interest van Holland, their petition insisted that the general interest would be greatly enhanced if all Dutch merchants were allowed to trade in Asia, while "the particular interest of the Chartered

${ }^{127}$ Ibidem I.19, p. 85-86: “... het waarhaftige Interest soodaniger Compagnien bestaat, in het meesten voordeel der gemeene Participanten te souken ... ende in het kort gesegt met de allerminste negotie ende navigatie, de meeste winsten te doen." Cf. the diametrically opposed view in Parker, Free Trade, 21-23.

${ }_{128}$ Aanwysing I.16, p. 72: “... soo maaken haar de seekere profijten dom en traag. Daar aan de andere zijde waarhaftig is, dat de nood een oud wijf doed draaven; ende de honger raawe boonen soet maakt; alsmede dat de armoede list soekt." See the similar passages in e.g. Welvaren 50, p. 113 and Politike Discoursen I.I.1, p. 7-8. Cf. also Walwyn, "Conceptions," 5: "The numerousness of Merchants will occasion a strife \& emulation among them, who shall produce the best ordered goods ... whereas Merchants in Companyes have noe need of such diligence."

${ }^{129}$ Aanwysing I.16, p. 76. The same fable is told in Sinryke Fabulen, 169-174. Cf. as well the comparable fables in Ibidem, 261-266, 347-354.

${ }^{130}$ All the documents concerning the project are published in Overvoorde (ed.), "Noord-Oostelijke doorvaart." 
East Indian Company is, on the contrary ... to alienate and exclude for eternity the common inhabitants of all knowledge, navigation and commerce of those Asian countries" ${ }^{131}$ In spite of these arguments, the second request was also rejected and the VOC maintained its monopoly. For the petitioners this clearly proved "the perniciousness of the company, which prefers that other nations come into the possession of such a considerable passage (if it could be found) instead of our own nation". ${ }^{132}$

De la Court's enterprise against the VOC is not only significant because it amounts to the most comprehensive criticism of the Dutch trading companies in the seventeenth century, but also because it differs in an important way from the dominant Grotian approach to freedom of trade. For Grotius and his followers, the crucial issue was the jurisdictional question of the dominion over the seas and hence the extent of the rights of navigation, fishery and trade. ${ }^{133}$ Yet De la Court's approach implies that free trade is not primarily a matter of right but of interest. This different emphasis is particularly clear in the largest chapter of the Aanwysing, which extensively discusses the need to rid the seas of pirates so as to safeguard "free Navigation", yet without a word on universal ownership or the law of nations. ${ }^{134}$ In the thought of the brothers De la Court, freedom of trade means not the collective freedom of the seas, but the freedom of individual merchants in a realm dominated by international rivalry and the premises of reason of state.

\section{From Natural to True Liberty}

De la Court's critical assessment of Holland's interest pivots on the claim that liberty, which should lead the way to commercial greatness, is in practice too much restrained in its many different facets - from the freedom of immigration to the freedom of enterprise. But what then does liberty' mean exactly? To answer this question I will show how the concept of liberty in the thought of the De la Courts merges a notion of individual

${ }^{131}$ Ibidem, 285: “... het particulier interest der Geoctroyeerde Oostindische Compagnie ter contrarie is ... Gemeene ingeseetenen van alle kennisse, navigatie en negotie der opgemelde Asiatische landen te vervremden en te secluderen in der eewigheid."

${ }^{132}$ Ibidem, 299: “... blijckt hieruuijt de quaedaerdigheijt van de compagnie, die liever heft dat andere natien de possessie van soo consideraebelen passage (bijaldien het te vinden waere) soude becomen dan onse eijgene natie."

${ }^{133}$ See Grotius, Free Sea, and cf. Den vryen handel ter zee, voor de Vereenighde Nederlanden (The Hague, 1666).

${ }^{134}$ Aanwysing II.1, p. 161: "Dat de vrye Zeevaart teegen alle Roovers en Vyanden sorgvuldiglik beschermd behoorde te werden." 
freedom as non-interference with a strong plea for republican 'True Liberty' in the sense of independence from any arbitrary domination. ${ }^{135}$

The different facets of freedom that the brothers De la Court propagate in their description of Leiden and Holland's commercial interest are based on the fundamental assertion that individuals do not relinquish their natural liberty when they agree to leave the state of nature for civil society. The establishment of sovereignty limits the freedom of all citizens through the rule of law, but the exercise of such freedom within the boundaries of civil law still involves a natural right that cannot be entirely alienated. ${ }^{136}$ In a vocabulary that echoes the Digests of Roman law, the De la Courts define this natural right as "the full freedom to do everything that is not conflicting with Politics and human society, either the freedom to serve God or to gain a living here [in Leiden] without the impediment by anyone and with whatever art, trade, or labour it may be". ${ }^{137}$ In other words, the natural liberty that is preserved in civil society entails the freedom from any obstruction of personal choices as long as these do not undermine society's raison d'être by bringing back the state of nature.

At first sight, this conceptualisation of liberty appears to be strictly negative: it emphasizes freedom from interference in religious and economic affairs, for example through persecution or the establishment of exclusivist monopolies. Yet this is not the whole picture, for the brothers De la Court maintain that human freedom involves more than merely the absence of interference. Following a long discussion of monarchical rule, a key section in the Politike Weeg-schaal under the general heading "On LIBERTY" draws a sharp distinction between, on the one hand, "the necessity to obey one man, called Servitude", and, on the other,

${ }^{135}$ For general notions of liberty in early-modern Europe, see esp. Werner Conze, "Freiheit," in Geschichtliche Grundbegriffe vol. II: 425-542. For the Dutch background, see E.H. Kossmann, "Het probleem van de vrijheid in de zeventiende-eeuwse Nederlandse Republiek," in Idem, Vergankelijkheid en continü̈teit. Opstellen over geschiedenis (Amsterdam: Bert Bakker, 1995), 63-86; and the various contributions to Haitsma Mulier and Velema (eds.), Vrijheid.

${ }^{136}$ See e.g. Aanwysing III.8, p. 518-519; Sinryke Fabulen, 97.

${ }^{137}$ Welvaren 17, p. 45: “... een volkoomen vrijheid, om alles te doen, 't geene tegen de Policie, en menschelijcke societeit niet strijdich is, 't sij om God te dienen, 't sij om sonder bekroon van ijmand, hier den kost te mogen winnen, met hoedanige konst, koopmanschap, of arbeid het soude mogen wesen." Cf. Digestae I.5.4 pr: "Libertas est naturalis facultas eius quod cuique facere libet, nisi si quid vi aut iure prohibetur." On seventeenth-century Dutch conceptualisations of natural liberty, see the useful article by Hans Blom, "Vrijheid in de natuurrechtelijke politieke theorie in de zeventiende-eeuw," in Haitsma Mulier and Velema (eds.), Vrijheid, 133-155. 
a State where no Man can dictate, but where the utmost is to appear in a certain assembly to cast one's vote so that a conclusion is reached with the majority of votes ... This State the Greeks and Romans have called liberty: because no one there is bound to live according to the will and desire of one man ... but to the spirit of order and Law, to which all Inhabitants of that State are uniformly subjected, as they are to Reason ... Therefore, no one in such a State is a Lord, and no one a Slave. Indeed, one can hardly call one of the residents in such a country a subject, since they are subjected to no one at all. ${ }^{138}$

Liberty, then, entails not only the absence of interference, but also the condition of self-government under the rule of law without being dominated by the arbitrary will of any other - a status diametrically opposed to that of a slave.

The brothers De la Court state explicitly that the vocabulary that underlies this passage stems from "the Rules of Roman Law"'139 the classical language of libertas codified in the Digests, which stress the dichotomy between those who are free and independent and those who are, as slaves, "within the power of someone else". ${ }^{140}$ The De la Courts imaginatively explain this glaring contrast between liberty and servitude in a number of fables. One fable tells of a hungry wolf who prefers his precarious but "precious liberty" in the forest above the opulent life of a dog who "is used to make himself a Slave to Humans and thus, by wagging his tail and sitting up, to beg them for a piece of bread". ${ }^{141}$ Another fable praises

${ }^{138}$ Politike Weeg-schaal II.I.1, p. 309-313: “Van de VRYHEID ... die noodzaakelikheid, om aan een mensch te gehoorsaamen hebben genoemd Slavernye ... zoodanigen Staat daar geen Mensch gebieden mag, maar daar het oppersten is te mogen verschijnen in zeekere vergaderinge, om aldaar zijn stemme te geeven, op dat, naar meerderheid der zelven werde gemaakt een conclusie ... Welke Staat de Grieken en Latinen hebben genoemd vryheid: alsoo niemand aldaarverbonden is, te leeven naar den wil en zin van een mensch, (daar zeer wel op te letten staat,) maar naar de zin van de ordre en Wet, aan welke alle Ingezeetenen van dien Staat, gelijk als aan de Reeden, eenpariglik onderworpen zijn ... en dienvolgende, is niemand in zoodanige Staat een Heer, ook niemand een Slaaf; ja naweliks mag men in zodanige landen, iemant der ingezeetenen een onderdaan noemen, dewijl zy aan geen mensch onderworpen zijn."

139 Ibidem, 313: “... de Regulen der Roomse Regten."

${ }^{140}$ Quoted in Skinner, Liberty before Liberalism, 41. Simon van Leeuwen, a prolific Leiden jurist and acquaintance of De la Court, edited the Corpus juris civilis for the publishers Blaeu and Elzevier in 1663. On Van Leeuwen's political views and his relation to De la Court, see Robert Fruin, "Over Simon van Leeuwen en zijn bedenckingen over de stadhouderlijcke magt," in Idem, Verspreide geschriften, ed. P.J. Blok, P.L. Muller and S. Müller (The Hague: Martinus Nijhoff, 1903), vol. VIII: 95-113.

${ }^{141}$ Politike Weeg-schaal II.I.2, 318: "dierbare vryheid." Sinryke Fabulen, 84: "De Hond daar en teegen is gewoon, sig een Slaaf der Menschen te maaken, ende dienvolgende soo met quispelstaarten als met opsitten, een stukjen broods van de selven te beedelen." 
the determination of a goldfinch who happily escapes his birdcage, confronting his former owner with the statement "that I could not live according to my own will, and that all my happiness or unhappiness depended continuously on your care or carelessness". ${ }^{142}$ Illustrated with these fables, the account of the De la Courts advances the fundamental argument that such liberty from arbitrary domination is only attainable in a free state where the citizens govern themselves. As the brothers insist, those countries where no one is a lord and no one a slave "are called Republics". ${ }^{143}$

This phrase obviously raises the question what this term 'republic' then exactly refers to - a question that I address in more detail below. A first glimpse of what the brothers De la Court meant by 'republic' becomes clear by their appropriation of the Roman language of libertas and its resurgence in Renaissance Italy. Boccalini was a first important source. In his revision of the Politike Weeg-schaal, De la Court included a ragguaglio on monarchical rule in which he translated Boccalini's libertà into the Dutch vryheid. He also turned Boccalini's distinction between patrie libere and altra spezie di governi into an explicit opposition of "Republics" versus "Monarchical Government" ${ }^{144}$ A second important source was the work of the infamous Florentine priest Girolamo Savonarola. In another revised passage, De la Court praised Savonarola for having revealed the hardships of servitude under the rule of the De Medici, translating one of Savonarola's powerful predications with vryheid for libertà. Revealingly, De la Court added that Savonarola's "Tyrant and Violator of liberty", Piero de Medici, "did not have such a great power in the Republic of Florence as a Stadholder does in the United Provinces". ${ }^{145}$ Finally, a passage on the demise of the Roman Republic, interspersed with quotes from Tacitus, puts vryheid explicitly in opposition to Augustus who "has violated the liberty of the

${ }^{142}$ Politike Weeg-schaal II.I.2, p. 318: “... dat ik naar mijn eige zin niet mogte leeven, en dat alle mijn geluk, ofte ongeluk geduurig van uwe zorg, ofte zorgloosheid dependeerde." The fable is also told in Sinryke Fabulen, 95-98.

${ }^{143}$ Politike Weeg-schaal II.I.1, p. 312: "Deeze Staaten en Landen werden nu genaamd Republiken."

${ }^{144}$ Cf. Ibidem I.III.11, p. 268-273 (not yet in the first edition), with Boccalini, Ragguagli I.21, p. $63-65$.

${ }^{145}$ Ibidem II.I.1, p. 310-311 (not yet in the first edition): “... dat Piero de Medici, (in de Republike van Florencen soo grooten magt niet hebbende, al seen Stad-houder in de Vereenigde Neederlanden) als een Tiran en Verkragter der vryheid." The predication partly translated by De la Court is of December 13, 1496, printed in Savonarola, Prediche sopra Ezechiele, ed. Roberto Ridolfi, 2 vols. (Rome: Angelo Berlardetti, 1955), vol. I: 69-102: 79 . 
Republic". Augustus is then suggestively described as "the Captain General or Stadholder of the Roman Republic". ${ }^{146}$

In this way, the work of the De la Courts unequivocally connects the language of libertas to the political situation in the Dutch Republic: liberty in the sense of non-domination cannot subsist under a monarchical figure such as a Stadholder. In the early 166os, this comparison between Piero de Medici and Augustus to the Dutch Stadholders was clearly invoked to warn the contemporary audience to refrain from ever appointing a Stadholder. At the same time, the fact that Savonarola had been burnt at the stake, that the De Medici dynasty eventually suppressed the Florentine Republic, and that Roman liberty gave way to Augustus' imperial domination, suggested something else too: that Holland, no longer subdued by a Stadholder, had surpassed the role models of Classical and Renaissance republicanism. While Machiavelli fashioned his ideal republic after victorious Rome, the De la Courts eschewed emulation and implicitly pretended that the libertas of Rome and the libertà of Florence were outshone by the beacon of Holland's 'True Liberty'.

To summarize, the concept of liberty in the work of the brothers De la Court moves from a negative notion of freedom from interference to a republican notion of freedom from monarchical domination. These two notions are not systematically distinguished in the brothers' work, and they prove to be far from mutually exclusive. The core of the De la Courts' thought, the common ground where the notions of non-interference and non-domination come together, is the contention that only true republics where the citizens govern themselves will safeguard freedom of movement and occupation and protect property rights and free trade. This blessed correlation "is the reason why usually, quippe ubi libertas ibi \& populus \& divitiae, all Republics are seen to flourish remarkably more in arts, commerce, population, and strength than Monarchical countries and Cities". ${ }^{147}$ In short, only republican liberty as opposed to monarchical domination can ensure the prosperity of a commercial commonwealth:

${ }^{146}$ Politike Weeg-schaal II.VI.3, p. 501-503: “... voor de Vryheid ofte teegen Augustus ... dat hy de vryheid der Republiek had verkragt ... de Kapitain Generaal, of Stadhouder der Roomse Republike, Augustus."

${ }^{147}$ Aanwysing I.1, p. 7: “... de reeden waarom men gemeenelik, quippe ubi libertas ibi \& populus \& divitiae, alle Republijken in konst-, koop-, volkrijkheid, ende sterkte, merkelik meer als de Monarchale Landen en Steden, sie bloejen." The quote is from Nicolas de Bourgogne, Historia Belgica (Antwerp, 1629), 5 . 
For the Inhabitants under this free Government, when they legitimately gain some treasures and riches, will possess these peacefully and they will be able to use them fully in line with their own perception, without fearing that a very needy and wasteful Lord or his Courtiers and Nobles, who are usually all just as wasteful, needy, and avaricious, will seize under any picked up cloak these treasures of the Subjects. Therefore, all Inhabitants here are much inclined to subsist through [various] means, and to win, save, and gather riches for their dear children. ${ }^{148}$

And thus the freedom from interference coincides with the freedom from domination as the foundation of the mercantile ethics of industrious frugality.

The thought of the De la Courts offers a clear example of the concept of republican liberty that Quentin Skinner has highlighted in his influential work on seventeenth-century English republicanism. ${ }^{149}$ The brothers' use of the concept, explicitly based on the Roman legal language of liberty as opposed to servitude that was revived in Renaissance Italy, reveals that they consciously positioned themselves in a long-standing tradition of republican liberty which originated in antiquity. Yet their fierce criticism of the Roman example and their emphasis on individual economic freedom also suggest that the De la Courts moved in a more 'liberal' direction which supposed a break with the classical past. Their case therefore shows that it can be difficult to draw a sharp opposition between republican and liberal notions of liberty: in the work of the De la Courts these two notions simply reinforce each other, for freedom from interference is only attainable when freedom from arbitrary domination is ensured. ${ }^{150}$ Overall, the De la Courts' 'liberal' argument for free enterprise and free trade neatly fits into a 'republican' criticism of monarchical rule in all its guises.

${ }^{148}$ Aanwysing I.8, p. 37: "Ende vermits de Ingeseetenen, onder deese vrije Regeeringe eenige schatten ende rijkdommen wettelik komende te winnen; de selve aldaar gerustelik besitten, ende naar hunne eigene sinnelikheid allesins gebruiken mogen; sonder te vresen dat eenig veel behouftig en quistend Opper-heer ofte sijne Hovelingen ende Edellieden, die gemeenelik alle ook eeven quistig, behouftig, en gierig zijn, gemelde schatten der Onderdanen onder den eenen ofte den anderen op geraapten dekmantel naar sig trekken sullen: soo zijn alle Inwoonders hier ook seer geneegen, om door gemelde ende andere leevensmiddelen te subsisteren, ende voor hare lieve kinderen rijkdommen te winnen, te sparen, ende te vergaderen."

149 See Skinner, Liberty before Liberalism, and Idem, Hobbes and Republican Liberty, esp. ix-xiii, 64-72, 144-148. For critical discussion, see esp. Sullivan, Machiavelli, Hobbes, 23-27, and Sommerville, "English and Roman Liberty."

${ }^{150}$ Cf. the comparable claim as regards English republicanism in Pincus, "Neither Machiavellian Moment nor Possessive Individualism” and Sullivan, Machiavelli, Hobbes. 


\section{MonARCHY DETHRONED}

\section{Good Government: The Harmony between Private \& Public Interests}

How should the government of a commercial commonwealth be organized? The answer of the De la Courts to this question largely derives from their commercial reasoning. Contrary to the institutional focus that dominates the few existing studies of their thought, I contend that the brothers' central argument against monarchy is based on their embrace of commerce as the mainstay of republican politics. For the De la Courts, commerce needs liberty, and such liberty can only be furthered by a broad representative assembly that establishes a harmony between private and public interests. In contrast, all forms of monarchical rule, including the Dutch Stadholderate, essentially amount to tyranny.

At the basis of the De la Courts' assessment of good government lies their implicit claim that the essence of politics is not the issue of sovereignty, but of interest. At odds with the dominant view of Bodin, Grotius, and Hobbes, ${ }^{151}$ the brothers De la Court suggest that the citizens and cities of Holland are not primarily connected through the institution of a unifying sovereign, but rather (if at all) by sharing a similar general interest. While Holland is characterized by a "variety of Rulers, Subjects, Lands, and situation" which "necessarily causes variety of interests", still "all its Cities and Lands concur in one thing or interest" ${ }^{\prime \prime}{ }^{22}$ Through a meticulous calculation of Holland's entire population and the rates of employment in all its different economic sectors, De la Court concludes that "all Inhabitants of Holland, living in freedom, are by a common well- and illbeing wonderfully linked together". This common ground is the all-embracing interest of commerce. ${ }^{53}$

In the preceding chapter I have discussed the tension between this notion of a general interest and the self-loving human condition that is central to the thought of the De la Courts. Following their claim that this tension can only be solved by the cultivation of well-understood

${ }^{15^{1}}$ See Skinner, "State of Princes to the Person of the State," 398-399.

${ }^{152}$ Aanwysing I.2, p. 20: “... dat verscheidentheid van Regeerders, Onderdaanen, Landen, en situatie, ook noodsaakelik verscheidentheid van interesten veroorsaakende ... soo veele alle sijne Steeden ofte Landen in eene saake, ofte interest overeenkomen." Cf. the less reassuring phrasing of the opening chapter of Interest I, p. 1: "Holland is geen een Land, en heeft niet allesins een interest."

${ }_{153}$ Ibidem I.9, p. 38: "Dat alle Ingesetenen van Holland, in vryheid zijnde, door een gemeen wel en qualik-vaaren, wonderlik aan een zijn gekoppeld." 
self-interest, civic virtue in the sense of subordinating personal advantage to the common good looses its classical prominence as the basis of politics. Consequently, the brothers De la Court insist repeatedly that good government can only be established upon the self-interested nature of rulers and rule alike. The common good will only be furthered if the rulers have something to gain personally from promoting the interests of all:

And therefore it is clear that A good government is not that where the well-or ill-being of the subjects depends on the virtue or vice of the Rulers, but, which is worthy of observation, that where the well-and ill-being of the Rulers necessarily depends on and follows from the well- and ill-being of the Subjects. For since one should assume that self is always preferred, so in the first case one's own advantage will be sought after even to the detriment of the common inhabitants. Yet because in the second case one's own advantage can only be obtained through the Common good, therefore the latter will always be aimed at by the Rulers. ${ }^{154}$

To put it more succinctly, the "true Interest of all Countries consists in the joint welfare of Rulers and Subjects." And given that "the Common good is not aimed at but for the sake of personal welfare, therefore the best Government is that where the Supreme Rulers can obtain their own welfare best and mostly by the Common good". ${ }^{155}$

At first sight, this correspondence between private and public interests does not appear to be particularly unconventional. In De officiis, Cicero similarly stressed that "the chief end of all men [ought to be] to make the interest [utilitas] of each individual and of the whole body politic identical." This influential phrase reverberated through early-modern political thought. ${ }^{156}$ Machiavelli insisted empathically that such a coincidence between private advantage and the common good is only possible

\footnotetext{
${ }^{154}$ Politike Weeg-schaal I.I.5, p. 34-35: "En dienvolgende zoo is klaar, dat Een goede regeering is, niet daar het wel ofte qualik varen der onderdanen, hangt van de deugd of ondeugd der Regeerders, maar, dat zeer aanmerkens-waardig is, daar het wel en qualik varen der Regeerders, noodwendig hangt van, en volgt op het wle en qualik varen der Onderdanen. Want vermits men geloven moet, dat eygen altijts voorgaat, zal in het eersten geval, eigen voordeel ook tot naadeel der gemeene ingezetenen werden gesogt. Maar vermits in het tweeden geval, eigen voordeel niet dan door het Gemeen kan werden verkreegen, zal het zelven door de Regeerders altijts werden betragt."

${ }^{155}$ Aanwysing I.1, p. 2, 6: "Namentlik, vermits aller Landen waarhaftig Interest, bestaat in het welvaaren der Regeerderen en Onderdaanen gesaamentlik ... dat het Gemeen niet dan om eigen welvaren betragt werd: ende dat het dienvolgende de beste Reegering is, alwaar de Opper-Regeerders haar eigen welvaren best en meest door het Gemeen verkrijgen konnen." See the similar passage in Ibidem III.1, p. 387-388.

${ }^{156}$ Cicero, De officiis III.VI.26, trans. Miller, p. 293.
} 
in republics. ${ }^{57}$ Hobbes argued "that where the publique and private interest are most closely united, there is the publique most advanced", which brought him to the diametrically opposite assertion that only "in Monarchy the private interest is the same with the publique". ${ }^{15}$ The brothers De la Court adopt this time-honoured concern of how to reconcile personal advantage with the common good, yet their approach entails a crucially different emphasis: the foundation of their analysis is not the public, but the private interest, the self-love that characterizes every human being. The common good can only be based on the pursuit of personal advantage, never vice versa. Accordingly, the De la Courts employ a Hobbesian view of mankind to reach a Machiavellian conclusion that only in republics the essential harmony between public and private interests will be sustained.

This claim follows from two connected assumptions. First, the education of princes and the sheer absence of discipline at a monarchical court determine that "Single Rulers rarely have that much judgment and knowledge that they can understand their own Interest well". ${ }^{159}$ Since a monarch is not able to identify his own interest correctly, he will be equally unable to make it coincide with the general interest of society at large. A monarchy that intentionally furthers the common good is therefore a mere chimera. Secondly, monarchs are not only unable to establish a harmonious connection between their self-interest and the welfare of the community, they deliberately oppose the general interest because of their characteristic lust for domination. Enslaved to their passions, they desire to enslave others and have their arbitrary power rule over the precepts of reason, thus proving the truth of the Italian saying La forza caca sopra la raggione. ${ }^{160}$ The eventual results are disastrous, in particular in a commercial commonwealth where the public interest consists of the increase of population and trade. As De la Court emphatically warns his Dutch readers, Holland's "laudable harmony and concurrence could be broken to the ruin of all Inhabitants ... by one single mistake: namely, by choosing a Supreme head over all these Inhabitants and their arms". Should this

${ }_{157}$ See Machiavelli, Discorsi II.2, p. 138: "E sanza dubbio questo bene comune non è osservato se non nelle repubbliche ... Al contrario interviene quando vi è uno principe: dove il più delle volte quello che fa per lui offende la città, e quello che fa per la città offende lui."

${ }^{158}$ Hobbes, Leviathan XIX, p. 241.

159 Aanwysing II.10, p. 305: “... de Een-hoofdige Regeerders selden soo veel verstands ende kennisse hebben, dat haar eigen Interest wel begrijpen konnen."

${ }^{160}$ Quoted e.g. in Politike Weeg-schaal III.II.4, p. 633, and Sinryke Fabulen, 285. 
occur, the existing harmony of interests would collapse under the domination of this monarchical figure and his followers:

And since the Lords, Courtiers, and Soldiers, who are devoted to him and depend on him, necessarily prey upon the industrious Inhabitants, therefore it appears that they would use all their power to their own advantage and at the expense of the common good ... and make all cities small and the Inhabitants poor, so that they can be obeyed without any opposition. If this is true, then it is clear that we should truly always pray to God a furore Monarcharum libera nos Domine: Oh God, please save Holland from a Monarch, Prince, and Head. ${ }^{161}$

\section{Turning Monarchy into Tyranny}

The principal intention that underlies the entire œuvre of the brothers De la Court is to reveal, like a modern Actaeon or the Dutchman in the Kingdom of Apes, the dangers and detriments of such monarchical furore. Their mercantile frankness aims to dethrone monarchy in general and the monarchical principle in the Dutch Republic in particular with the general assertion that all modes of single rule are incompatible with the liberty that represents the highest law of a commercial commonwealth. Essentially, this endeavour collapses the Aristotelian distinction between monarchy and tyranny: as the De la Courts contend, "Monarchy, where one man may command, is the Government that the Greeks and Romans of old have called Tyranny". ${ }^{162}$

This crucial statement arises from a general rhetorical strategy of extensive prolepsis and paradiastole, directed against the conventional Aristotelian wisdom that monarchical government as opposed to tyranny

\footnotetext{
${ }^{161}$ Aanwysing I.9, p. 45: “... deese loffelike harmonie en overeenstemming soude konnen werden gebrooken, tot ruine van alle Ingesetenen ... met eene eenige misslag; naamentlijk, met te kiesen een Opper-hooft over alle de selve Ingeseetenen ofte der selver wapenen ... ende dat de Heeren, Hoovelingen, en Soldaaten, alle hem toe gedaan zijnde, ende van hem dependerende, noodwendig op de arbeidende Ingeseetenen aasen, soo schijnd, dat sy alle haare magt souden gebruiken tot eigen voordeel, en tot nadeel van 't gemeen ... dat zy kennelik alle Steeden klein, ende de Ingeseten arm maaken souden, om zig sonder teegenspreeken te konnen doen gehoorsaamen. 't Welk indien waarhaftig is, soo is kennelik, dat men hier te regt altijds God behoorde te bidden, a furore Monarcharum libera nos Domine. O God: bewaard dog Holland voor een Monarch, Prins, en Hoofd." See Welvaren, 143, and Politike Weeg-schaal I.III.11, p. 273, for the same prayer, following a fable taken from Boccalini.

${ }_{162}$ Politike Weeg-schaal II.I.1, p. 309: “... Monarchie, daar een enkeld mensch gebieden mag, welke Regeering de Grieken en Latinen van ouds hebben genoemd Tirannie." For the Aristotelian distinction between monarchy and tyranny, see Aristotle, Politics V.10 (1310b). Cf. also Boxhorn, Institutiones I.IV.3-4.
} 
is conducive to the common good. ${ }^{163}$ According to the brothers De la Court, the duplicitous speech that proliferates under monarchical rule is responsible for this widespread mistake. The flattery of courtiers and political writers who live under a monarchical yoke implies that in such a regime, "the truth is more concealed, so that the deeds of Monarchs are always elevated above the truth" ${ }^{164}$ Such dissimulation means that the vices of kings are commonly heralded as virtues and that their "ambition and desire to rule" are lauded. ${ }^{16_{5}}$ The consequence is that rulers like Caesar and Augustus, "those horrible Monsters, are still praised by most Historians as if they had been very pious Heroes" ${ }^{166}$ Even in the Dutch Republic such admiration of kings remains influential, with the result that many think that the monarchical incivility embodied by the House of Orange deserves the same esteem as the exemplary civic behaviour of the wise merchant:

And therefore one will say that the Prince of Orange should be praised for his expansion and growing authority and power in serving or Governing the United Netherlands as much ... as a diligent and honest Merchant, who knows how to accumulate his goods by Industry and Trade, is commonly esteemed and lauded. For apparently, all Prince's business and Commerce consist in that accumulation of Power. ${ }^{167}$

In short, courtly hypocrisy obscures the vital distinction between honourable mercantile ambition and the disastrous monarchical desire to dominate.

The brothers De la Court contend that thus far in history there has been only one author who dared to speak his mind to a monarch: George Buchanan, whose work "can serve as a brightly shining beacon to all

${ }_{163}$ This strategy dominates the entire first book of Politike Weeg-schaal, esp. I.I.8-11, and is repeated throughout the entire œuvre of the De la Courts, esp. in the third part of the Aanwysing.

${ }^{164}$ Politike Discoursen II.V.4, p. 109: “... de waarheid bedekter is: sulks de daaden der Monarchen altijd booven de waarheid werden verheft." Cf. Machiavelli, Discorsi I.58, p. 128: “... de' principi si parla sempre con mille paure e mille rispetti."

${ }^{165}$ Aanwysing, 'Voor-reeden', sig. ${ }^{* * * *}$ 2v.: “... dat de groote ambitie ofte heersugtigheid in Koningen ende Princen seer pleeg gepreesen te werden."

${ }_{166}$ Sinryke Fabulen, 463: “... die schrikkelijke Gedrogten als nog by de meeste Historieschrijvers gepreesen, als of het seer vroome Helden waaren geweest." Cf. Politike Weegschaal I.I.12, p. 65, for a similar passage.

${ }^{167}$ Aanwyisng, "Voor-reeden," sig. ${ }^{* * * * *} 2$ v.: "Ende dienvolgende, soo schijnd iemand te sullen seggen, datmen de Princen van Oranjen over haare vermeerderinge ofte aanwassende authoriteit ende kragt in het bedienen ofte Regeeren der Vereenigde Neederlanden ende der veroverde Steeden, alsoo seer behoorde te prijsen, alsmen te agten ende te looven pleeg een vlytig eerlik Koopman, die sijne goederen door Neeringe ende Negotie weet te vermeerderen; want in die vermeerderinge van Magt kennelik alle der Princen hanteering ende Negotiatie bestaat." 
contemporary Historians who would like to write scandalous truths about Monarchs". ${ }^{168}$ With this praise of Buchanan's repudiation of "flattery, which is the nurse of Tyranny, and a most grievous plague of a Kingdome", the De la Courts clearly position themselves in the Monarchomach tradition. ${ }^{169}$ Yet unlike Buchanan, they do not maintain that kings are bound to uphold the social contract and that resistance is lawful if they forsake this duty. Instead, the brothers make a decisively more radical move by insisting that monarchy is by its very nature unconducive to the salus populi. Even when checked by the rule of law or balanced in a mixed regime, monarchy is and remains tyrannical.

The De la Courts insist that monarchs consider the population over which they rule as enemies and therefore "try to decrease the power, honour, and goods of their subjects as much as possible". ${ }^{170}$ A monarch aims to subdue the people as "tame and powerless" horses, "so that they cannot refuse the bit and bridle or imposts and obedience"; he restrains their cities through garrisons and citadels instead of protecting them with defensive fortifications, and he imposes all kinds of taxes to finance his wasteful pleasures and his expensive royal household. ${ }^{171}$ Moreover,

Monarchs hate studies and knowledge, since they consider it dangerous when many people tower above Them in intellect. And because they realize that an intelligent Community is not tyrannized or ruled as peacefully as one that is less intelligent, therefore these Monarchs extinguish all knowledge as much as they can. ${ }^{172}$

${ }^{168}$ Politike Weeg-schaal I.I.33, p. 161: "En dienvolgende soo kan gemelde Buchananus, tot een hel-schijnent baken strekken, voor alle hedendaagse Historie-schrijvers, die geneegen souden mogen wesen van Monarchen aanstotelike waarheeden te schrijven."

${ }^{169}$ George Buchanan, De jure regni apud Scotos. Or a Dialogue, Concerning the Due Priviledge of Government in the Kingdom of Scotland (s.l., 1680), sig. A5. Pieter de la Court van der Voort owned the 1643 Edinburgh edition of Buchanan's Rerum Scoticarum historia, published together with De jure regni apud Scotos: Library, fol. 28. On Buchanan, see Skinner, Foundations, vol. II: 339-348, and J.H. Burns, "George Buchanan and the AntiMonarchomachs," in Phillipson and Skinner (eds.), Political Discourse, 3-22.

${ }^{170}$ Politike Weeg-schaal I.I.11, p. 52: “... de magt, eere, en goederen hunner onderdanen zoo zeer tragten te verminderen als doenelik is."

${ }^{171}$ Aanwysing I.1, p. 3-4: “... soo mak ende magteloos blijven, dat sy niet souden konnen breidel ende toom ofte schatting ende gehoorsaamheid weigeren." The passage on the erection of citadels refers to Aristotle, Politics V.11, VII.11, and also evidently follows Machiavelli, especially Discorsi II.24. Cf. also Aanwsying III.2, which refers directly to the Politike Weeg-schaal, esp. I.I.13 and I.I.28.

${ }^{172}$ Politike Discoursen II.V.9, p. 133: "Ende om de selfde reden haten de Vorsten de studien, en geleerdheid; want Sy gevaarlik agten, dat veele booven Haar in verstand uitsteeken; ende siende dat een verstandige Gemeente, sig soo vreedsaam niet laat tiranniseren, of regeren als een onverstandiger, soo blussen deese Vorsten alle geleertheid soo veel uit, als sy konnen." 
The overall result is that a commonwealth under monarchical rule will never be able to prosper in liberty. Instead, monarchies only promote licentiousness. Kings spend their days among their concubines, and thus often leave daily administration to their favourites or, at best, they sell state offices to the highest bidder. Indecisiveness, nepotism, and corruption are the inevitable consequences. ${ }^{173}$ The rule of law is all but absent in a monarchy, for "all orders and laws will conduce privatively to the advantage of the King and his Courtiers". ${ }^{174}$ In sum, the private interest of the sovereign is not harmoniously connected to the general interest, but pursued at the expense of the common good.

This gruesome fate is especially catastrophic for a society based on commerce. Since monarchs and courtiers can enrich themselves effortlessly by imposing taxes and selling offices, it is unthinkable that they would "seek their maintenance by an uncertain gain with the danger of losing all in that ever laborious and anxious Commerce". ${ }^{175}$ The dominant ethics of a courtly society, based on laziness, easy gains and squandering, are fundamentally incompatible with the mercantile ethics of a commercial commonwealth. Kings and courtiers will therefore do their best to frustrate all trading activity. "Under a Single-headed Government", De la Court warns, "the Lords and their Courtiers envy and deadly hate the most fortunate Owners of Freight-ships, as well as the Merchants and Traders, because with their legally obtained Riches and the use thereof they obscure the lustre and pomp of the Court and Gentry" ${ }^{176}$ This monarchical jealousy of trade in turn leads to even more excessive taxes and the establishment of monopolies to line the courtiers' purses, which constrain economic freedom. Accordingly, the rule by a king and his corrupting court fundamentally thwarts the preservation and increase of the polity, the prime principle of reason of state. Monarchs forsake the necessary defence of the country, and instead of establishing

${ }^{173}$ See Politike Weeg-schaal, esp. I.I.11-27, and cf. the similar passages in Aanwysing I.1 and III.2, and e.g. in Sinryke Fabulen, 277-278.

${ }^{174}$ Politike Weeg-schaal I.I.27, p. 126: “...dat alle ordre en wetten zullen strekken privativelik, ten voordeele des Konings en zijner Hovelingen.”

${ }^{175}$ Aanwysing III.2, p. 423: “... sijne onderhoud door een onseeker gewin, met perikel van alles te verliesen, in de altijds arbeidsame ende bekommerlike Koopmanschap te soeken."

${ }^{176}$ Ibidem, 434: "Sulks dan waarhaftig zijnde, dat onder de Een-hoofdige Regeeringe, de Heeren en haare Hovelingen ... de gelukkigste Reeders in Vragt-scheepen, als ook Koopluiden en Negotianten benijden, ende doodelik haaten, om dat sy door hunne wettelik verkregene Rijkdommen, ende het gebruik van dien, den Hoofsen ende Adeliken praal ende glans verduisteren." 
profitable colonies overseas, they wage offensive wars to conquer new territories. ${ }^{177}$

All of which brings about that the people, sighing under the burdens of their Monarch, under the injustice and pillaging of their Governors, and living in continuous insecurity about their lives and goods, do not employ diligence to accumulate goods, nor do they have desire to marry and to breed children, who will be led to the slaughters of war as slaves of the Monarch..$^{178}$

Thus a commonwealth based on commerce and learning will necessarily disintegrate when it is enslaved to such domination, for merchants "shun and should flee from such a government like from a deadly Plague". ${ }^{179} \mathrm{De}$ la Court stresses that worldwide historical experience shows that this has been exactly the case, from the imperial Pre-Columbian courts of Cuzco, Quito, and Mexico to the large cities of Japan, China, Persia and India, and from Fez and Cairo to Nineveh and Jerusalem. ${ }^{180}$ All these instances reveal that if a people lives under domination by the arbitrary will of one man, commerce will collapse: because "in general, commerce always disappears from those countries and cities where one single man can rob a Merchant at his pleasure of his goods; that is, in short, from all monarchical government" ${ }^{181}$

\section{Paradigms of Tyranny}

An important part of the Politike Weeg-schaal discusses at length various instances of such monarchical rule and its ruinous consequences. The first and most prominent of these paradigms of tyranny is the Ottoman Empire - a commonplace element of comparison in early-modern European political thought from Bodin to Harrington. In line with the prevailing 'orientalist' depiction of Eastern despotism which can be traced

177 Ibidem, 437-439, and Politike Weeg-schaal I.I.28-29.

${ }_{178}$ Politike Discoursen V.II.9, p. 134-135: "Alle het welk te weege brengd, dat het volk onder de lasten van haar Vorst, onder de onregtvaradigheid, en plondering van haare Gouverneurs sugtende, en leevende in geduurige onseekerheid van haar leeven, en goederen; geen naarstigheid gebruikt, om goederen te vergaaderen, nog lust heeft om te trouwen, en kinderen aan te queeken, die als slaaven van den Vorst in de oorlogen ten slagtbanken werden gevoerd."

${ }^{179}$ Politike Weeg-schaal I.I.13, p. 72: “... de Koopluiden, van zoodanige regeeringe niet min schuw zijn, en vlieden moeten, als van een doodelike Pest."

${ }^{180}$ Aanwysing III.3, p. 443-444. De la Court refers to Blaeu's Atlas and to a Dutch translation of José de Acosta, Historia natural y moral de las Indias (1590).

${ }^{181}$ Welvaren 37, p. 82: “... in 't generael verloopt de negotie altijds uijt ende van die landen en steden, daer een eenigh mens een Negotiant na sijn gelieven, van sijn goederen kan berooven, dat is met eenen woorde geseght van alle monarchale regeringe." 
back to Aristotle, ${ }^{182}$ the De la Courts' overview abhors the ignorance and devastation among the Turkish lands and the decadence and cruelty of the Sultan. ${ }^{18^{3}}$ In particular, the De la Courts insist that "those of Asia have always been fainthearted, feminine, and childish, those of Africa dumb and slavish ... but those of Europe have always been more courageous, manly, diligent and rational". ${ }^{84}$ Yet in spite of this conventional defence of European superiority, the De la Courts do not consider the Ottoman case as an example of fundamental otherness, typical to the particular culture and mores of the Orient or to Islam. Instead, the brothers list approvingly the Islamic rules of life and they insist that "under a Christian Religion those Lands would have been still much more destroyed" ${ }^{185}$ The Ottoman Empire offers therefore a universally valid warning that monarchy degrades humanity.

The only reason that Western Europe has for the most part not yet become prey to this fate, and that "under the Christian European Monarchs science, commerce, wealth, arts and virtues are not yet extinguished", is because of the republican legacy of Antiquity and the resulting decentralization and fragmentation of power. But the De la Courts feared this tide was changing. Just fairly recently in history, they argued, the European kings had started to reveal their truly tyrannical face. "The evil effects of Monarchical government are therefore, essentially, to be expected in due time." ${ }^{186}$ In 1685 , the year when Louis XIV crowned his absolutist rule with the revocation of the Edict of Nantes, De la Court saw these earlier fears justified. In the preface to the Sinryke Fabulen, he wrote:

Especially in our Century, Single-headed Rule, both in Church and State and suppressing so many Free Republics, has come to the fore to such an extent, that if it would continue among the Tyrants with the same pace for

${ }^{182}$ See Patricia Springborg, Western Republicanism and the Oriental Prince (Cambridge: Polity, 1992), and Joan-Pau Rubiés, "Oriental Despotism and European Orientalism: Botero to Montesquieu," Journal of Early Modern History 9, 1-2 (2005), 109-180.

${ }^{183}$ See Politike Weeg-schaal I.II.2-22. This overview is largely based on the massive work of Francesco Sansovino, Historia universale dell'origine et imperio de' Turchi (Venice, 1561) and on the Voyage du Levant by the French envoy Louis Deshayes, baron of Courmenin, a travel account first published in 1624 .

${ }^{184}$ Politike Weeg-schaal I.III.1, p. 230: “... die van Asien zijn altijt kleynhertig, verwijft, en kinderlijk, die van Afriken dom, en slaafs geweest ... Maar die van Europen zijn t'allen tijden stouter, manneliker, arbeydzaamer en vernuftiger geweest."

${ }^{185}$ Ibidem I.II.22, p. 227-228: "... dat die Landen, onder een Christelike Religie, nog veel meer verwoest zouden weesen."

${ }^{186}$ Ibidem I.I.34, p. 168-169: “... onder de Christelike Europise Monarchen, de geleerdheydt, koopmanschap, rijkdom, konsten en deugden niet uitgebluscht ... Sulks die quade effecten der Monarchale regeeringe, nu voorneementlik, met der tijdt te verwagten staan." 
yet another Century, then also in the whole of Europe all salutary Knowledge, Sciences, good Arts, Virtues and Riches of the People, indeed the People itself in number, will be diminished, just like we see it now in Muscovy, Greece, Turkey, Persia, India, \&c., unless God Almighty would forbid it miraculously. ${ }^{187}$

De la Court's pessimism stems from the crucial claim that there is in due course no fundamental difference between an overtly despotic monarchy such as the Ottoman Sultanate and a monarchy that is checked by laws and constitutional contract. This assertion involves a significant departure from the conventional republican credo that a king who respects the law is not the same as a tyrant. For Machiavelli, the Roman emperors who lived sotto le leggi deserved at least a bit of praise, ${ }^{188}$ while Milton made sure to deny "that all kings are tyrants". "As much as a good man differs from a bad", Milton insisted, "so much, do I maintain, that a king differs from a tyrant". ${ }^{189}$ Yet for the brothers De la Court, this distinction between monarchy and tyranny fails because it does not take into account the baseness of human nature. They acknowledge that monarchical government under the law may be slightly better than a state "where a Monarch rules absolutely and without fear", but it is still a government based on the principle of a single ruler, who is human and who will therefore necessarily try to free himself from the reins of the law. ${ }^{190}$ The recent history of France, Spain, and England - the standard examples of pure monarchy in the academic politica - was for the De la Courts a case in point of this predictable fate. ${ }^{191}$

${ }_{187}$ Sinryke Fabulen, "Voorreeden," "** 4v.: “... dat bysonderlik in deese onse Eewe de Eenhoofdige Regeering, soo in Kerke als in Staat, ter onderdrukkinge veeler Vrye Republiken, soodaanig is doorgedrongen, dat indien geduurende nog eene volgende Eewe, met dieselfde treeden by den Dwingelanden werd voortgevaaren, ook door geheel Europa alle heilsaame Kennissen, Weetenschappen, goede Konsten, Deugden ende Rijkdommen der Menschen, jaa de Mensche selfs in getaale, verminderd staan te werden; Eeven gelijk wy dat nu in Moscovien, Griekenland, Turkien, Persien, Indien, \&c. zien; ten zy God Almagtig sulks wonderlik verhoede."

188 See Machiavelli, Discorsi I.10, p. 34-35.

${ }_{189}$ Milton, Defence of the People of England and Second Defence, in Idem, Areopagitica and Other Political Writings, 148, 324. Cf. on absolutist theories that equally emphasized the difference between monarchy and tyranny Wolfgang Weber, "What a Good Ruler Should Not Do': Theoretical Limits of Royal Power in European Theories of Absolutism, 1500-1700," The Sixteenth Century Journal 26, 4 (1995), 897-915.

${ }^{190}$ Politike Discoursen II.V.10, p.145: “... dat sy nog beeter zijn, als daar een Monarch absolutelik, en sonder eenige vreese, regeerd."

${ }^{191}$ Politike Weeg-schaal I.III.2-7, based on De Perefixe and Fajardo, and on the survey in Jean Pinson de La Martinière, Estat et gouvernement de France, of which numerous editions were published throughout the 1650 s. 
England is thus unequivocally classified as a monarchy, which may seem surprising given the English republican experiment of the 1650 s. Revealingly, the brothers De la Court remained largely silent about the fate of the English Commonwealth. Apart from De la Court's letter to Harrington of New Year's Eve 1672 and the manuscript reference to Harrington's Oceana, there is no direct evidence that the brothers were familiar with English republican thought. This can be explained by the fact that few English publications were available on the Dutch market, while Dutch enthusiasm for the English republican experiment was from the outset rather meagre. ${ }^{192}$ Of all contemporary English republican writings, only Milton's Defensio pro populo Anglicano, published in $165^{1}$ in reply to the Leiden academic Claudius Salmasius, was disseminated widely in the Dutch Republic, both in its Latin version and in French and Dutch translations. ${ }^{193}$ Milton indeed wrote this treatise with an international audience in mind, and he frequently addressed the Dutch directly. ${ }^{194}$ Nevertheless, his Dutch audience remained rather reserved about Milton's endeavour to justify the establishment of the English Commonwealth. While Isaac Vossius, the son of the rhetorical theorist, stressed that he "had expected nothing of such quality from an Englishman", another scholar, Nicolaas Heinsius (the former schoolmate of De la Court) aptly summarized the general Dutch sentiment by arguing "not so much that a bad cause has been well pleaded by Milton as that Scribonius [i.e. Salmasius] has pleaded most abominably the cause of the unfortunate King". ${ }^{195}$ The execution of Charles I had met with widespread condemnation in the Dutch Republic - the Dutch, after all, had abjured but never decapitated their king in the days of the Revolt - and for all his zeal, Milton could not significantly change that attitude. ${ }^{196}$ Other important

${ }^{192}$ See P.G. Hoftijzer, "The English Book in the Seventeenth-Century Dutch Republic," in Hellinga et al. (eds.), Bookshop of the World, 89-107, and cf. Marika Keblusek, "The Exile Experience: Royalist and Anglican Book Culture in the Low Countries (1640-166o)," in Ibidem, 151-158.

193 Joannis Miltons Engelsmans verdedigingh des gemeene volcks van Engelandt, tegens Claudius sonder naem alias Salmasius Konicklijke Verdedigingh [1651]. The library of Pieter de la Court van der Voort held this edition: Library, fol. $3^{2 .}$

${ }^{194}$ See Milton, Defence of the People of England, esp. 105. For Milton's intentions to convince the Dutch, cf. Worden, Literature and Politics, 202-203.

195 Quoted in H. Scherpbier, Milton in Holland. A Study in the Literary Relations of England and Holland before 1730 (PhD dissertation University of Amsterdam, 1933), 6, 13.

${ }^{196}$ See e.g. Vondel's poem "Op den Vader-moort in Groot-Britanie," in Werken, vol. V: 476. On Dutch public opinion about Cromwell, see Daniël Grosheide, Cromwell naar het oordeel van zijn Nederlandse tijdgenoten (Amsterdam: Noord-Hollandsche Uitgevers Maatschappij, 1951). 
writings in defence of the republican regime in England, from the newsbooks and treatises of Nedham to Harrington's Oceana, were never published in the Netherlands, let alone translated into Dutch. ${ }^{197}$

This absence of English sources partly explains why the De la Courts had so little to say about the English Commonwealth. Yet perhaps a more important reason for their relative silence is that the English revolution and Cromwell's eventual supremacy offered the brothers an example of "mutatio tyranni, non tyrannidis ablatio". As they insisted when discussing monarchical rule: "We must not take away the name King, but the thing King." ${ }^{\prime 198}$ This phrase, which vaguely echoes a comparable saying of Nedham, ${ }^{199}$ reveals that the supremacy of Cromwell and the eventual Restoration were for the De la Courts a sign that the English commonwealth was no true republic, but rather the same monarchy in different guise. The brothers maintained that England's violent past proves that even when a monarch is balanced by a powerful parliament, political upheaval is all too common. Therefore, "this blessed, fertile country", even though it never experienced similar warfare as continental Europe, "has still remained so lowly only because of the Monarchical government" ${ }^{200}$ It was clear to the De la Courts that the English, though doing their best to compete with the Dutch, would never be able to accomplish the same mercantile success as a truly free commercial commonwealth. ${ }^{201}$

Having thus disposed of England as yet another paradigm of tyranny, the brothers De la Court continue to discuss the distinct type of polity that is not subjected by a hereditary monarchy but by a ruler who is chosen ad vitam. The subjects in such a state probably fare better than those living under the yoke of absolutism, yet they are still dependent on the passionate whims of one man. Following a commonplace in Florentine political thought from Machiavelli to Guicciardini, the De la Courts discuss two examples of such "Monarchs in fieri": the Papal States, which

197 Revealingly, the only work of Nedham translated into Dutch was his anti-French pamphlet Christianissimus christianandus (Amsterdam, 1678).

${ }_{198}$ Politike Weeg-schaal I.I.32, p. 157-158.

199 Nedham, Excellencie, 155: “... onely the name King was expelled, but not the thing” (referring to the Tarquins).

${ }_{200}$ Politike Weeg-schaal I.II.7, p. 256: "Zulks dit gezeegende, vrugtbare landt, ook met hondert jaaren vreede, en zoo veel oorlogs onder alle de nabuuren, moet werden gelooft, zoo laag gebleeven te zijn, alleen door de Monarchaale regeering." See also the remarks on England in Politike Discoursen I.II.9, I.II.26, and Sinryke Fabulen, 725, which refers to Thomas Smith, De republica anglorum, published in the 'Republics' series of Elzevier.

${ }^{201}$ Aanwysing I.22, p. 99, and see De la Court's letter to Harrington discussed in the Introduction above. 
"should be loathed and eradicated", and the Mamluk Sultanate in medieval Egypt and Syria, in their words "the Saracen Republic that was so monstrous that it should be smothered". ${ }^{202}$ The De la Courts' version of the history of the Mamluks, based in particular on the fifteenth-century travel account of the Flemish nobleman Joos van Ghistele, discusses in detail the procedures of the election of the sultan, and it stresses that the regime was exceptionally beneficial for Mediterranean trade. ${ }^{203}$ But in spite of these positive qualities, the Mamluks remained under the domination of one ruler. Therefore they merely exemplified "lesser Slavery", for "Republics provided with a Head ad vitam who has any Military power, are truly Monarchies, or become so" ${ }^{204}$ Overall, then, the extended discussion of all various guises of monarchical rule, from the Ottoman Empire to the Mamluk Sultanate, involves a clear rhetorical strategy: to assert that any form of monarchy, no matter how moderate or balanced, necessarily involves servitude. The purpose of this strategy is of course obvious, and indeed, the Politike Weeg-schaal explicitly classifies Holland under the Stadholders as one of the monarchies in fieri. ${ }^{205}$

\section{The Dutch Republic: Lion or Ass?}

The precise intention of this move becomes clear in the context of the Dutch political debate on the position of the Stadholder in the years following the failed coup d'état by William II and the subsequent establishment of the regime of 'True Liberty'. Towards the end of the 165os the debate between the supporters of the House of Orange and those who defended the status quo remained fundamentally undecided. On one side, the miscellaneous front of Orangists propagated the mixed republican regime balanced by a Stadholder, while De Witt and his allies maintained in reply that the principle of non-hereditary offices prolonged the time-honoured Batavian model. The brothers De la Court attempted to move beyond this stalemate by arguing that any form of single rule within

${ }^{202}$ Politike Weeg-schaal I.IV.4-6, p. 307-308: “... minder Slavernye en Monarchen in Fieri ... in allen manieren behoorde te verfoejen en te verdelgen ... die Sarrasinise Republik, sy was soo monstrueus, dat men die behoorde te smooren." Cf. Machiavelli, Principe XIX, p. 136-137, and the description of the demise of the Mamluk Sultanate in Francesco Guicciardini, La historia d'Italia (Venice, 1567) XIII, p. 647-648.

${ }^{203}$ For a modern edition of Joos van Ghistele's travel account, see Ambrosius Zeebout, Tvoyage van Mher Joos van Ghsitele, ed. R.J.G.A.A. Gaspar (Hilversum: Verloren, 1998).

${ }_{204}$ Politike Weeg-schaal I.IV.6, p. 308: “... dat de Republiken voorsien met een Hooft, ad vitam, eenige magt in den Oorlog hebbende, waarlik Monarchien zijn, ofte werden."

${ }^{205}$ Ibidem I.IV.1-2. 
a republican constitution, hereditary or not, undermines the harmony within the body politic and ultimately brings about its demise. Thus emerges their radical assertion that, no matter how moderate or balanced, any monarchical figure is essentially a tyrant. In order to vindicate this claim, the brothers departed from both the conventional Aristotelian emphasis on the tripartite mixed regime and from the Batavian model of Grotius and instead turned to the binary opposition of liberty versus servitude. Heavily equipped with this republican language of liberty, the De la Courts entered the Dutch rhetorical battlefield to assail the Orangist positions and thus win over the middle ground in the debate. ${ }^{206}$

This verbose attack starts in the first edition of the Politike Weeg-schaal with a decided yet still relatively cautious attempt to persuade those who doubt the risks involved in appointing a Stadholder. Following the detailed survey of all the examples of monarchical tyranny, this attempt centres on the message that if one man is appointed as a Stadholder, Holland sets foot on a stairway to servitude. As the De la Courts insist: "Damned for eternity be the name of the Man who knowingly gives in his free Fatherland the first step to the Monarchical government, for all other steps will follow necessarily" ${ }^{207}$ In his later revision, De la Court then adds more force to this statement with a warning to those "Lovers of Liberty" who think "that the road to Servitude and Monarchical government is steep enough to give away some steps". Directly addressing these middle groups who had not been convinced by the anti-Orangist argument of De Witt, De la Court stresses that "someone who is on the first step to make himself Lord of the Republic" will easily obtain the favour of the military and the "ignorant Rabble", and thus eventually command an indomitable alliance of anti-establishment sentiments. "And therefore", De la Court concludes, "it is the truth that the liberty of a Republic can only remain intact by cautiously taking care not to put anyone, under whatever lovely name or cover, on the lowest first step of exceptional power". ${ }^{208}$

${ }^{206}$ For a comprehensive overview of the Orangist ideology that the De la Courts argued against, see Stern, Orangism.

${ }^{207}$ Politike Weeg-schaal I.III.9, p. 261-263: "Vervloekt zy des Menschen naam in der eeuwigheit die willens en weetens in zijn vry Vaderlant, na de Monarchaale regeering de eerste treede geeft, want alle anderen moeten noodzakelik volgen; (primas dominandi spes in arduo, ubi sis ingressus adesse studia \& ministros. C. Tacitus.)" The suggestive quote is from Tacitus' description of Sejanus, confidant of Tiberius, in Annals IV.7.

${ }^{208}$ Ibidem, 261-263 (not yet in the first edition): "Dog indien eenige Liefhebber der Vryheit, van meeninge zijn ... dat de weg ter Slavernie en Monarchale regeeringe zo steil niet is, of dat men in de selve wel eenige treeden geven, en dan nog blijven staan kan; zo gelieven de selven te gedenken, dat iemant die op den eersten trap is om sig Heer der 
One of these 'lovely names' that De la Court had in mind was the title of Captain-General, the office of commander-in-chief over the Republic's armed forces which traditionally belonged to the Stadholder. The military command was one of the crucial issues in the Dutch political debate since many, and not only the committed Orangists, claimed the necessity to appoint a single supreme military leader to protect the country. The De la Courts suggestively undermine this claim. Again and again, they subtly hint to the implications of appointing a Captain-General by calling respectively Caesar, Augustus and Tiberius "the Captain-General of the Roman Republic". ${ }^{209}$ Other passages and fables, drawing largely on Machiavelli and Boccalini, insist with similar meaningful obliqueness that the reputation and authority granted to a military leader open up the gates to tyranny. ${ }^{210}$

These passionate but still implicit references to the dangers of appointing a Stadholder or a Captain-General become much more overt in the Interest van Holland and especially in the revised version of the work, the Aanwysing, published two years after the signing of the Perpetual Edict that formally abolished the office of the Stadholder. In this new context, De la Court markedly increases the bluntness of his anti-Orangist assault, extensively quoting from the text of the Edict to substantiate his views. ${ }^{211}$ First, he maintains with much hyperbole "that never any Country has been in such great servitude as Holland during or under the Service and Rule of the Princes of Orange". This assertion is further elaborated throughout the work. Until 1650, De la Court repeatedly insists, Holland suffered under the monarchical yoke of the Stadholders, and only God's intervention prevented a life in eternal slavery with the sudden death of William II. ${ }^{212}$

Republike te konnen maken ... het onwetende Graaw ... En dienvolgende zo is waaragtig, dat de vryheid eener Republike niet kan werden staande gehouden, dan met sig sorgvuldiglik te wagten, iemand onder wat lieffelike naam en dekmantel het zy, te setten op de minste eerste trede van uitsteekende magt."

${ }^{209}$ Ibidem, "Inleyding," p. 2: “... die wreede Capitain Generaal der Roomse republike Tiberius." Similar references to Caesar, Augustus and Tiberius e.g. in Ibidem I.IV.1, p. 280; I.IV.2, p. 293; II.VI.3, p. 503; and Sinryke Fabulen, 655. Aanwsying II.1, p. 211, compares Stadholder Frederik Hendrik to Augustus through a telling quote from the opening lines of Tacitus, Annals I.2.

${ }^{210}$ See esp. Politike Weeg-schaal I.III.10-11, and Politike Discoursen I.III.11. Cf. Machiavelli, Discorsi I.40, III. 28.

${ }^{211}$ Aanwysing II.12, p. 338-341.

${ }^{212}$ Ibidem, "Voor-reeden," sig. .* 2v.: “... dat noit eenig Land in soo groote slavernye, als Holland gedurende, ofte onder de Dienst ende de regeeringe der welgemelde Princen van Oranjen, geweest zy." References to the salvation of liberty by the premature death of William II e.g. in Ibidem, sig. ${ }^{* * * * *}$ v.; I.25, p. 130; III.1, p. 417; III.4, p. 474. 
Thus began the period of True Liberty, which De la Court, unlike De Witt, does not characterize as the absence of hereditary power but as the inexistence of any arbitrary domination - the possibility to lead a peaceful life in accordance with the law "without being forced, like before, to speak, sing, and dance to the piping and will of one Man". ${ }^{213}$

A number of rhetorical moves substantiate this assertion that Holland under the rule of the Stadholders was not a true republic but merely a monarchy in disguise. A first move intends to show that the Princes of Orange inherited a long tradition of monarchical imperiousness of the Counts of Holland - a direct confutation of the Orangist claim that the Stadholders upheld a time-honoured Batavian heritage of well-balanced government. ${ }^{214} \mathrm{~A}$ second move then involves a refutation of another standard element of the Orangist republican credo: the view that the Dutch Republic had gained its independence thanks to the prudence and guidance of the various Stadholders in the war against Spain. ${ }^{215}$ The De la Courts daringly turn this conventional image upside down through a rhetorical redescription of the role of William the Silent, the pater patriae. First, they hint with a quote from the Spanish diplomat Fajardo (that is, from the side of the former enemy), that William the Silent only pretended to fight for liberty but in fact deliberately caused upheaval and thus established a "much more unbearable Servitude" than before. ${ }^{216}$ Then, in the Aanwysing, De la Court intensifies this move with the rhetorical question whether "these Countries have been in harsher slavery under the Service of the Princes of Nassau, or under the Domination of the Habsburgs?" Of course, no answer follows, yet the suggestion that there is no fundamental difference speaks for itself. ${ }^{217}$

${ }^{213}$ Aanwysing II.12, p. 342: “... sonder sig als voordeesen genoodsaakt te vinden, naar eenes Mans sin en voorpijpen, te moeten spreeken, singen, en dansen.”

${ }^{214}$ See Politike Weeg-schaal I.IV.2, Aanwsying I.25, and the entirety of Historie der gravelike reeegering.

${ }^{215}$ See e.g. Onwederleggelycke bewys-redenen daer door betoont wort, dat de Vereenighde Nederlanden, alleen door Godts voorsieninge ende der Princen van Orangien beleyt, van Spaensche jock, ende slavernije vrij gemaeckt zijn (Willemstad, 1663).

${ }^{216}$ Politike Weeg-schaal I.IV.2, p. 289-290: “... een veel onverdraageliker Slavernie,” following a quote from Fajardo, Idea, symb. 78 .

${ }^{217}$ Aanwysing II.11, p. 323: “... of deese Landen onder den Dienst der Nassowsen, ofte onder de Heerschappye der Oostenrijkers, in hardere slavernye waren geweest?" The question is based on a verse in Latin, borrowed from Aitzema, Saken van Staet en Oorlogh, vol. VII, 809: "Servivi Auriacis famulis, dominisque Philippis: dic mihi conditio durior utra fuit?" - to which Aitzema tellingly adds that the difference between 'Auriacis' (i.e. the Princes of Orange) and 'Austriacis' (the Habsburgs) consists merely of the letters 'st'. 
In this way, De la Court boldly depicts the Dutch Stadholderate as merely a rippling reflection of the Habsburg monarchy. In a next move, he then openly argues that the appointment of a Captain-General is no lesser evil than to empower a Stadholder. With a telling quote from Lucan's Pharsalia, De la Court asserts that a man who commands the military has all the means and reputation to overrule any opposition. This military commander should therefore be considered noting but a "Sovereign, a Monarch of that State ... and accordingly, such a Government should no longer to be called a Republic, but a Monarchy in practice and in fact". The fate of the Roman Republic, again illustrated by a quote from Lucan, proves that only the shadow of liberty remains when men bow to such military might. ${ }^{218}$ Under a Stadholder or a Captain-General Holland would equally "lose the name and the appearance of a Free Republic in a very short time, and change into an evident Monarchical or Single-headed Government". Merchants and commerce would then inevitably flee the country, and the deplorable result would be "truly a Country without Inhabitants, a Body without a Soul, and a lamentable fountain of unspeakable misery". ${ }^{219}$

All the different threads of the argumentation of the De la Courts come together in the final and most important rhetorical move against the Orangists: the overarching claim that the particular interest of the Stadholder cannot possibly coincide with the general interest of Holland at large. Holland, based on trade, needs liberty, yet a Stadholder will only enhance servitude. Like any monarch, he will enforce large taxes to weaken his subjects and to finance his decadent court. This is what the Princes of Orange have done in the past, as a result of which the Dutch "more than any people in the world seem to be sentenced to labour like Asses and to eat thistles in order to subsist". ${ }^{220}$ Such hyperbole serves the obvious purpose of contradicting the Orangist argument that Dutch commerce

${ }^{218}$ Ibidem III.1, p. 391-392: “... Souverain, Monarch van dien Staat ... ende dat men dienvolgende soodanige Regeringe niet meer eene Republike, maar eene Monarchye te weesen in practik ende inder daad, behoorde te seggen." The quotes from Lucan that illustrate this passage are from Pharsalia III.145-147, and X.407.

${ }^{219}$ Ibidem III.7, p. 517-518: “... door het maaken van een Stadhouder ofte een Capitein Generaal, ad vitam ... de naam ende de schijn eener Vrye Republike in seer korte Jaaren soude verliesen, ende veranderen in eene baarblijkelijke Monarchale ofte Eenhoofdige Regeeringe ... waarelik een Land sonder Inwoonders, een Lighaam sonder Ziele, ende eene beklaaglijke waaterpoel van onuitspreekelike ellenden, soude weesen."

${ }^{220}$ Politike Weeg-schaal I.IV.2, p. 294: “... dat zy meer als eenige volkeren des werelds schijnen verweezen te zijn, gelijk als Eezels te arbeiden, en distelen te eeten, om te mogen leeven." 
had prospered under the rule of the Stadholders. De la Court develops this argument further with a meticulous overview of the economic policies of all Stadholders from William the Silent to William II, concluding that had the last Prince of Orange not died so suddenly, "commerce and navigation would have been subjected here to the same demise as in all other Monarchical Countries". ${ }^{221}$ In short,

for all free States, and especially for those founded on Knowledge and Commerce, no greater disaster can be thought of than to fall from a free City or Republic to a Monarchical Government, where commonly all knowledge, arts, virtues, Wealth and commerce are destroyed, and the Inhabitants devoured like bread. ${ }^{222}$

To substantiate this assertion that a commercial commonwealth cannot persist under monarchical domination, De la Court enumerates a range of illustrious trading cities of the past that lost their prosperity along with their liberty, such as the Phoenician cities of Sidon and Tyre. Ancient Sidon, "whose Inhabitants lived in complete peace and certainty under a Free Republic without having a Supreme Head or King over them", is now deprived of its former wealth under Ottoman domination, "since the Inhabitants cannot peacefully possess their riches and sciences under this Monarchical or Princely Government". Tyre was struck by a similar fate, and thus "these two Republics lost their navigation and commerce not by Wars or Earthquakes ... but by the loss of their Free Government". ${ }^{23}$ Further examples of this essential link between liberty and commerce abound: Carthage, Athens, Rhodes, exemplary republics which all lost their trade and liberty to the Romans; the republics of the Italian Renaissance, like Pisa, Florence and Milan, which "when they obtained

${ }^{221}$ Aanwysing III.IV, p. 476: “...dat de koopmanschap en schipvaart, \&c. hier deselve ondergang, als in alle andere Monarchale Landen, onderworpen zijn geweest." The chapter builds heavily on passages from De Witt's Deductie. Cf. as well Ibidem, "Voor-reeden," sig. ${ }^{* * * * *}$, and II.1, p. $236-237$.

${ }^{222}$ Welvaren 64, p. 143-144: “... van alle vrije Staeten, insonderheid die op Geleerdheid en Koopmanschap sijn gefondeerd, dat voor deselve grooter rampsalicheid niet kan werden bedaght, als van eene vrije Stad ofte Republijck te vervallen tot een Monarchale Regeeringh, daer gemeenelick alle geleerdheid, konsten, deughden, Rijkdom ende koopmanschap vernietight, ja de ingesetenen verslonden werden als brood."

${ }^{223}$ Aanwsying III.3, p. 444-449: “... wiens Inwooners leefden in volkome rust en seekerheid, onder eene Vrye Republike, sonder Opper-hoofd ofte Koning over sig te hebben ... alsoo de Ingeseetenen onder deese Monarchale ofte Princelike Regeeringe haare rijkdommen en wetenschappen niet souden konnen gerustelik besitten ... En dus siet men, dat deese twee Republiken haare schipvaart ende koopmanschap, door geene Oorlogen ofte Aard-beevingen ... hebben verlooren; maar dat sy deselve alleen door het verlies van haare Vrye Regeeringe zijn quijt geworden." 
the Court of a Monarch or his Stadholder much decreased in commerce during the Monarchical Government"; and finally, at the end of the list, the Dutch Republic itself, which had a narrow escape yet faces an insecure future. ${ }^{24}$

All these examples issue an unmistakable warning to those who argue in favour of a Stadholder. Their crime, De la Court stresses daringly, is "similar to Adam's first sin", with the same everlasting catastrophic consequences for posterity. ${ }^{225}$ The Orangists who boast that they are the true patriots are in fact traitors to their country, because "it is a ridiculous stupidity and a damned folly, or detestable treason against the state, to install in one's free Fatherland any Head, however it be, over Politics, Justice, or the Military". ${ }^{226}$ In a final rhetorical move, De la Court addresses the supporters of the Stadholder directly in a potent exclamation that merges biblical imagery with biting wit:

You bastards from the Tribe of Judah! You who have dared to carry for so long a Lion in your escutcheon, erase, erase that old blood-coloured Lion, whom you are unworthy in every way. And as true children of Issachar, carry instead in your decorous escutcheon a strongly boned Ass oppressed under a double burden. ${ }^{227}$

In 1672, the Dutch lion was indeed to show its true nature. Some thirteen years later, in his swansong the Sinryke Fabulen, De la Court lamented its fate in the implicit yet well-understood terms of the proverb "wherever an ass falls, there will he never fall again": in spite of the fact that God's intervention in 1650 had freed Holland from a tyrant, the Dutch appointed a new one in $1672 .{ }^{228}$ Once more, De la Court repeated his anti-Stadholder mantra, stressing "how great Servitude or miserable condition it is to live in a Country where the well or ill-being, yes the Life or Death of all

${ }^{224}$ Ibidem, 458: “... de Hof-houding des Monarchs ofte sijns Stadhouders bekoomen hebbende, seer in koopmanschap afgenoomen zijn, geduurende de Monarchale Regeeringe."

${ }_{225}$ Ibidem III.7, p. 517: “... gelijk als Adams eerste sonde.”

${ }^{226}$ Politike Weeg-schaal I.III.8, p. 258: “... is het een bespottelike dwaas- en een vervloekte dolligheyd, ofte een verfoeijelijke landverraderij, in zijn vry Vaderland eenig Hooft, hoedanig het zy, over de Politie, Justitie, ofte Militie in te voeren." Cf. Ibidem I.IV.1, p. 282, for the same charge of high treason against the Orangists.

${ }^{227}$ Ibidem I.IV.2, p. 298 (not yet in the first edition): "Gy bastaart-kinderen uit den Stamme Juda! die zoo langen tijd een Leew in uwen schild hebd derven voeren, wisch uit, wisch uit, dien ouden bloedverwigen Leew, wiens gy in aller manieren onwaardig zijt. En als waaragtige kinderen van Issaschar, soo voer in teegendeel tot u welvoegend wapen, een sterk gebeende Eezel neder-gedrukt onder eenen dubbelden last."

${ }^{228}$ Sinryke Fabulen, 160: “... dat een Eezel sig niet meer dan eens stoot aan den selfden steene." For a similar rhetorical move, see Ibidem, 98. 
Inhabitants of the Country, depends on the favours or disfavours of one single Man". ${ }^{29}$ He could not say more, he insisted, for under the new regime of William III, "a solemnly proclaimed Oblivion" forbade the remembrance of the near past, "since those wounds are too fresh to be scratched open". ${ }^{230}$ Now was no time for parrhèsia, De la Court realized, yet his message remained obvious. The Dutch commercial commonwealth had stood at crossroads, one way leading to prosperity-in-liberty, the other to decadence-in-servitude. It had chosen the latter.

\section{TOWARDS A MERchant DEMOCRACY}

\section{Republic: A Sovereign Assembly in Name \& in Fact}

To summarize, the fundamental principle that underlies the political thought of the brothers De la Court is the statement that "it is truly the best Government where the Rulers and most of the Inhabitants cannot find their Self-Interest and Welfare but with furthering the welfare of the Community". ${ }^{231}$ This harmony between private and public interests can never be sustained under monarchical domination, for any form of single rule necessarily undermines the common good. The De la Courts' alternative is a republican government that fosters liberty instead of servitude, but the question remains what kind of republic exactly meets this criterion. In short: what is a true republic according to the De la Courts?

In early-modern political thought, the term 'republic' was characterized by an elementary ambiguity. Originally, following Cicero, the words res publica stood for any kind of legitimate government, monarchical or not, as opposed to tyranny. ${ }^{232}$ This use of the term remained widespread throughout the seventeenth century, when 'republic' was often employed in the same neutral terms as its literal translation 'commonwealth', devoid of any non-monarchical connotation. In the academic politics as taught

${ }^{229}$ Ibidem, 361: “... hoe groote Slaavernie ofte ellendige stand het is, te woonen in eenen Lande, daar het wel- ofte quaalik-vaaren, jaa Leeven ofte Dood aller Ingeseetenen eenes Lands, hangd van de gonsten ofte afgonsten eenes eenigen Mensche." Cf. also Ibidem, 46, 143-144.

${ }^{23^{\circ}}$ Ibidem, 315, 585: “... eene plegtiglik afgekondigde Vergeetelheid"; "Want die wonden te vers zijn om oopen gekrabt te mogen werden."

${ }^{231}$ Ibidem, 185: “... dat het waarelik de beste Regeeringe is, daar de Regenten ende de meeste Ingeseetenen, haar Eigen-Interest ende Welvaaren niet vinden konnen, dan met het Welvaaren van het Gemeen, te besorgen."

${ }^{23^{2}}$ Cicero, De re publica, ed. and trans. Clinton Walker Keyes (Cambridge, Mass.: Harvard University Press, 1928) I.XXV-XXVI.39-42, p. 64-66. 
at Leiden, a res publica stood for the political order in which a body of individuals obtains the status of subjects under a single overarching central authority. Boxhorn, for example, defined a 'republic' very generically as "a body of many established for the advantage of all and every individual to acknowledge the authority of the government over that body by certain laws". ${ }^{233}$ Other representatives of academic politica, from Arnisaeus to Werdenhagen, defined 'republic' in largely comparable terms. ${ }^{234}$

Yet significantly, Boxhorn added an explanation to his definition of 'republic' indicating that the term had obtained a further gradation of meaning. Boxhorn stressed that his definition applied to every sort of government, including that of a single ruler, but because such a ruler "often puts public after private, or is ensnared by the temptations of lust, or when inclining to tyranny inflicts the more damage the more powerful he is, therefore it occurs that res publica is contrasted with Monarchy". ${ }^{235}$ With these words, Boxhorn neatly captured a second meaning of the term 'republic' that had crept slowly but steadily into the political discourse of the various European languages. The roots of this altered meaning lay in Renaissance Italy, particularly in Florence, which, as a free city-state ruled not by one but by many, claimed to embody the true res publica in opposition to a polity governed by a monarch. A crucial text in the establishment of this opposition was Machiavelli's Principe, which in the opening lines famously subdivides all states as either republiche or principati. ${ }^{236}$ In the course of the sixteenth-century, this non-monarchical meaning of the term 'republic' became common in Italian, and throughout the next century it spread over the rest of Europe, challenging the dominance of the established Ciceronian understanding. ${ }^{237}$

This second definition of 'republic' as a polity that is opposed to a monarchy clearly dominates the work of the brothers De la Court. Two crucial

${ }^{233}$ Boxhorn, Institutiones I.II.1, p. 8: "Respublica est corpus multorum ad agnoscendam ejusdem Imperii Majestatem, iisdem legibus, omnium \& singulorum utilitatis causa, imbutum."

${ }^{234}$ Cf. Arnisaeus, De republica II.I.1, and Werdenhagen, Politica generalis II.I.5.

${ }^{235}$ Boxhorn, Institutiones I.II Exp., p. 10: "Respublica quam hic definimus pro quovis imperio usurpatur, etiam pro eo, cui unus praeest, si modo ille saluti obedientum consulat. At quia saepe is aut publica privatis postponit, aut illecebris voluptatum rapitur, aut ad tyrannidem inclinans tanto plus infer damni, quanto potentior est, obtinuit, ut Respubl. Monarchiae fere opponatur."

${ }^{236}$ Machiavelli, Principe I, p. 1: "Tutti li stati, tutti e dominii che hanno avuto et hanno imperio sopra li uomini, sono stati e sono o republiche o principati."

${ }_{237}$ See the painstaking but rather unstructured overview in Wolfgang Mager, "Republik," in Geschichtliche Grundbegriffe, vol. V: 549-651, and cf. the more concise and more useful discussion in Hankins, "Exclusivist Republicanism." 
chapters in the Politike Discoursen unequivocally claim "That a Republic is better than a Monarchy", even that "The best Monarchical Government is not as good to the Subjects as the worst Republican Government" ${ }^{238}$ Thus the brothers move beyond the cautious remark of their teacher Boxhorn, and they explicitly equate monarchy with tyranny and republic with liberty. Using the same Ciceronian language that opposes legitimate to tyrannical government, the De la Courts radically undermine the classical connotations of res publica by insisting that a monarchy is necessarily tyrannical and only a republic is truly legitimate.

A republic, then, is essentially "a State where no Man can dictate" - a state where the sovereignty is vested in an assembly of many, where the law governs all and where arbitrary domination by a single man is impossible. Yet this generic definition does not encompass the De la Courts' concept of a republic in its entirety. As De la Court argues, a definition solely in terms of sovereign right is bound to be insufficient in a realm of de facto politics. He therefore insists that a republic not only entails "such a State, where a certain Sovereign Assembly has all the Right and Power to take, make or break resolutions, orders and laws ... [but] also such as State, where a certain Assembly, even though without any Right, has the Power to have all its resolutions, orders and laws being obeyed". ${ }^{239}$ In short, a true republic means the government by an assembly that is not only sovereign in name, but also in fact. This contention stems from De la Court's assertion that a state where a single man can usurp power without any right is effectively a monarchy. "Right is totally idle without force, and where violence comes it must always cease”, De la Court insists. ${ }^{240}$ The theoretical issue of the location and administration of sovereignty does not establish the main distinction between republics and monarchies - an important move away from the conventional Grotian defence of the States of Holland vis-à-vis the Stadholder. All that

${ }_{238}$ Politike Discoursen II.V.4, p. 105: "Dat een Republijk beeter is als een Monarchie." Ibidem II.V.9, p. 131: "De beste Monarchale Regeering, is den Onderdaanen soo goed niet, als de geringste Republikse Regeering."

${ }^{239}$ Aanwysing III.1, p. 388: "Naamentlik, met den woorde Republike en Republikse Regeerders versta ik, niet alleen soodanige Staat, waar in seekere Souveraine Vergadering alle Regt ende Kragt heeft, om alle resolutien, ordren en wetten te nemen, te maaken, ofte te breeken ... maar ik verstaa daar meede ook soodanige Staat, waar in eenige Vergaaderinge, schoongenomen sonder eenig Regt, de Kragt heeft alle haare resolutien, ordren en wetten te doen gehoorsamen."

${ }^{240}$ Ibidem, 389: “... Regt dat sonder kragt gansch ydel is, ende daar geweld komt altijd ophouden moet." 
matters in reason of state politics is the actual ability to enforce one's interest. A republic, consequently, is a polity where the government is in the hands of an assembly that has sufficient coercive power to ensure that the harmony of interests is not jeopardized by the ascendancy of one man; in short, "such an Assembly where, for the large amount and the diversity of Members, self-Interest cannot be pursued and obtained at the expense of the common welfare" ${ }^{241}$

\section{Aristocracy \& the Pitfalls of Paucity}

What sort of assembly is best equipped for this task? In line with the conventions of academic politica, the brothers De la Court discuss two variations of republican government as alternatives to tyrannical monarchy: either aristocracy, basically defined as "an assembly of some people", or democracy, "an assembly of all people capable". ${ }^{242}$ In a clear rhetorical move to uphold the ethos of the objective, impartial guide through the labyrinth of politics, the Politike Weeg-schaal lists all the advantages and disadvantages of both aristocracy and democracy, and then continues to balance the particular merits of each specific form of government. Largely written by Johan and later modified and extended by Pieter de la Court, this overview clearly reveals the intricate and at times conflicting collaboration between the two brothers.

Following a central claim advanced by Machiavelli, the De la Courts insist that in general, the advantage of a republican assembly lies in the plurality of its members. Mastering the art of speech, "many people can always hear, see, and know more than one", while the competition between all members of an assembly will create "diligence and sincerity" as well as cautiousness. In a direct echo of Machiavelli's dictum that "a people is more prudent, more stable and of better judgment than a prince", the De la Courts conclude that

in an assembly of equally powerful Members, there is always a large variety of passions, which keep each other in check without insight of own benefit. Thus, when it comes to political matters, reason finds always more place in

${ }^{241}$ Sinryke Fabulen, 107: “... in soodaanige Vergaaderinge, waarin, om het groot getal, ende de verscheidenheid der Leeden, eigen Interest ten naadeele des gemeenen welvaarens, niet konnende bejaagd ende verkreegen werden."

${ }^{242}$ Politike Weeg-schaal I.I.4, p. 33: “...in een vergaaderinge van eenige menschen in de Aristokratia of in een vergaaderinge allermenschen des bequaam zijnde in een Demokratia." Cf. Boxhorn, Institutiones II.I.1, p. 257: "Inde Monarchia, in qua singuli; Aristocratia, in qua pauci; Democratia, in qua omnes praesunt." 
legitimate assemblies than in one man, whose judgment is frequently stunned by the passions. ${ }^{243}$

In theory, therefore, the larger the assembly is, the better, because the plurality of members enhances competition between their passions, which eventually keeps a check on individual wrongdoing. Yet in practice, such plurality may result in long deliberations and lack of decisiveness. Since the members of an assembly have "not only variety of interest but also of judgment", the sovereign power might fall apart through intrigues and discord. ${ }^{244}$ Therefore, the crucial issue is of the optimum dimensions the governing assembly should assume in order to benefit from the advantages of plurality without suffering under its disadvantages.

The first possibility is aristocracy, described in conventional Aristotelian terms as a government "where an assembly of people, being born or chosen thereto, has to command and all others outside of that assembly are to obey". ${ }^{245}$ The fundamental advantage of this aristocratic ruling body lies in the eminence of its members, who can be expected to have enjoyed a good education and therefore will understand how to connect their selfinterest to "the right Interest and welfare of the Country". ${ }^{46}$ Yet an aristocracy also has numerous flaws, of which the De la Courts stress three in particular. First, if the members of an aristocratic assembly vote openly, they are liable to be manipulated by the strongest among them, who will then get hold of the "power and act of Government". Thus, such aristocracies, though "Republics in name", will become "close to Monarchies

${ }^{243}$ Politike Weeg-schaal II.I.3, p. 320-321: “... dat veele menschen altijd meer hooren, zien en weeten konnen, als een ... naarstigheid en opregtigheid ... dat sig in een vergaderinge van eevenmagtige Leeden, altijd een groote verscheidentheid van passien oopenbaard, die ook, zonder inzigt van eigen baat, malkanderen in den toom houden; zulks de reeden, in wettige vergaaderingen, omtrent politike zaaken, altijds meer plaatse vind als by een mensch, wiens verstand door de passien veeltijds verdoofd werd." Cf. Machiavelli, Discorsi I.58, p. 126: “... un popolo è più prudente, piu stabile e di migliore giudizio che un principe ... molte volte erra ancora un principe nelle sue proprie passoni, le quali sono molte più che quelle de' popoli."

${ }^{244}$ Politike Weeg-schaal II.I.4, p. 327: “... niet alleen verscheidenheid van interest, maar ook van oordeel."

${ }^{245}$ Ibidem I.I.6, p. 35: “... een vergaadering van menschen, daar toe gebooren ofte verkooren, heeft te gebieden, en alle anderen buiten die vergaaderinge weezende te gehoorzaamen." Cf. Burgersdijk, Idea oeconomicae et politicae II.XXII.1, p. 118: “Aristocratia est status in quo excellentioribus aliquot, jus majestatis, \& imperium in caeteris concessum est."

${ }^{246}$ Politike Weeg-schaal II.II.2, p. 335: “... dat het regte Interest en welvaaren des Lands, door gemelde Leeden zeer wel kan worden begrepen, en dat een yder, die in 't gemeen zijn eigen voordeel betragten kan, zoo veel in hem is, niet zal toelaaten, dat het Gemeen, en hy te gelijk schade lijde." 
in fact" ${ }^{247}$ Secondly, aristocratic assemblies are likely to fall into discord and factions. This happens particularly when guild masters are granted membership, for they can mobilize their entire profession to put pressure on the rest of the assembly. Finally, the third flaw of an aristocracy is that, since "the Members of the sovereign assembly are so few", it runs the risk of becoming an "Oligarchy, Dominatio Paucorum, stato da pochi [sic]". The ultimate consequence is that "in such a Government the interest of the Rulers will always precede, also at the detriment of the common good". ${ }^{248}$

With this assertion that an aristocracy is likely to lapse into either monarchy or oligarchy, the brothers De la Court adopt a standard refutation of a closed government of the few, echoing Machiavelli, who argued that a government of ottimati easily becomes a stato di pochi, ${ }^{249}$ and Boxhorn, who equally insisted that an aristocracy often changes into monarchy or into Tacitus's paucorum dominatio. ${ }^{250}$ The De la Courts continue to discuss extensively how the advantages and disadvantages of aristocracy are revealed in the constitutions and republican practices of contemporary and historical examples of aristocratic government, from Venice and Genoa to Sparta and Rome. As Haitsma Mulier has shown in detail, when revising the Politike Weeg-schaal De la Court gave particular praise and attention to the republic of Genoa. In Genoa, according to De la Court, the large ruling councils and the constant rotation of office prevented the demise of true republican government. ${ }^{251}$ Yet Haitsma Mulier does not highlight that the reference to this international model clearly served to criticize the Dutch status quo, the oligarchic governing bodies in Leiden and Holland at large.

This criticism specifically involved a strong repudiation of the size of Leiden's ruling council of forty, the veertigraad. In line with their general discussion of aristocratic government, the De la Courts argued that so small an assembly will not be able to resist the preponderance of one imperious member or the external pressure of guilds. As they insisted, it is

${ }^{247}$ Ibidem II.II.3-5, p. 339, 344: "Maar dat de kragt en daad van Regeering, meest is by dat uitsteekend Lid ... Republiken met naame; bij naast Monarchien in der daad."

${ }^{248}$ Ibidem II.II.6, p. 348: "Het derde grootste gebrek der Arsitokratike Regeeringe, bestaat in Oligarchie, Dominatio Paucorum, stato da pochi ... als de Leeden der souveraine vergaderinge zoo weinig zijn." Ibidem II.VI.5, p. 514: “... zoo zal in zoodanige Regeeringe altijd het interest der Regeerders voortgaan, ook tot nadeel van het gemeen."

${ }^{249}$ Machiavelli, Discorsi I.2, p. 11: “... gli Ottimati con facilità diventano stato di pochi.”

${ }^{250}$ Boxhorn, Institutiones I.3 Exp., p. 21, quotinq Tacitus, Annals VI.42.2. See also Ibidem II.V.11, II.VII.3.

${ }^{251}$ See Politike Weeg-schaal II.V.1-11, and the analysis in Haitsma Mulier, Myth of Venice, $147-157$. 
very improbable "that ever a Republic has been able to uphold its Free Government against the world's incidents, both from the inside and from the outside, with as few members as forty". ${ }^{252}$ In other words, a republican assembly that excludes a large part of the citizenry will easily fall prey to nepotism or succumb to one leader, who will then destroy republican liberty. Therefore, the De la Courts concluded, it is "humanly impossible" that Leiden's government would "subsist in such an unequal rule by so few people". ${ }^{253}$ This same risk loomed large in most Dutch cities, for while the urban population had increased drastically in the seventeenth century, the size of the ruling town councils had remained the same. All over Holland the "disproportion between Rulers and Subjects has become much larger" and consequently "that Rule by a few people (Paucorum Dominatio) will not be tolerated for a long time by the idle and uncomfortable Subjects in case the industry and the welfare decline". ${ }^{254}$

The brothers De la Court thus argued that the closed urban aristocracies of Holland ought to open up their ranks to comply with the changing demography and to preserve the lawful government vis-à-vis an insecure future. This contention involved a fundamental criticism of the political status quo in Holland under the De Witt regime. ${ }^{255}$ The De la Courts contended that the Dutch aristocratic republican government in power was on the brink of lapsing into oligarchy and, sooner or later, into the monarchical domination by a Stadholder, because it did not represent the general citizenry at large. This critical deviation from the dominant ideology of the establishment clashed openly with the views of De Witt himself in the months prior to the publication of the Interest van Holland. In the manuscript version of this treatise, De la Court argued that none of Holland's citizens ought to be excluded from the government by laws: citizens from foreign descent should be granted the right to be elected to

\footnotetext{
${ }^{252}$ Welvaren 71, p. 153: “... dat oijt een Republijk hare Vrije Regeeringh heeft konnen staende houden tegen de gevallen des werelds soo van binnen, als van buijten met soo weinich leden als veertich." This chapter refers explicitly to the examples of Sparta, Genoa and Lucca.

${ }_{253}^{25}$ Ibidem 79, p. 170: “... dat de Regeeringh in soo een ongelijke heerschingh van soo weinigh menschen niet bestaen kan, menschelijcker wijse gesproocken."

${ }^{254}$ Politike Weeg-schaal II.II.6, p. 350: “... zoo is die disproportie, tussen Regeerders, en Onderdaanen veel grooter geworden; en is te verzen dat die (Paucorum Dominatio) Heersching van weinig menschen, by verminderinge van neering, en welvaaren, by leedige en ongemakkelike Onderdaanen, niet zal konnen werden lang gedragen."

${ }^{255}$ For a lucid overview of the oligarchic character of Dutch government and the formal and informal limits to civic participation in politics, see Henk van Nierop, "Popular Participation in Politics in the Dutch Republic," in Peter Blickle, Resistance, Representation, and Community (Oxford: Clarendon Press, 1997), 272-29o.
} 
the urban councils. In a cynical mode, he then added that such a right, though beneficial in theory, would in practice only be "an idle wind", since the "few rulers would always agree on excluding the foreigners in fact, and prefer to leave that privilege to their families instead of to strangers". This sarcastic remark, which clearly alluded to the nepotistic practices of the ruling regent families, was smothered by the censorious interference of De Witt himself, who erased it from the text with a fervent stroke of his aristocratic pen. ${ }^{256}$

In another passage, De la Court voiced his criticism of the powers-inbeing still more openly. Discussing the reasons why the Dutch Republic had not profited much more from its recently gained liberty, he argued that the existing government was, although much better than the rule by a Stadholder, still far from perfect, given that many judiciary offices were exercised for life by members of the elite families. As De la Court cried out: "I do not know what an oligarchy is if it cannot be seen here." He then continued with a strong rebuttal of De Witt's foreign policy, too bellicose in his eyes and only conducive to high taxes instead of commercial diligence. ${ }^{257}$ On reading these lines, De Witt deleted the entire passage and replaced it with two large chapters which, on the basis of a concept written by himself, justified in a densely informed prose the "resolute management by the pious Rulers in Holland" ${ }^{25}{ }^{8}$ Clearly, then, a simplistic classification of the brothers De la Court as mere propagandists of the De Witt regime is untenable. Although the Interest van Holland was deployed as propaganda by De Witt cum suis, the De la Courts directed their criticism not only against the Stadholderate but also against the closed ruling circles that maintained power among themselves through nepotism and patronage. What they did approve in the regime of De Witt was its new republican élan, yet their goal was not as much to support this regime as to transform it into a genuine government of True Liberty.

\section{Democracy \& the Pitfalls of Public Speech}

The arguments that the De la Courts put forward against aristocracy spring from their assessment of the specific economic and political

${ }^{256}$ The passage is published in Veegens, "Johan de Witt," 45: “... een ijdele wind ... soo weinig regeerders altijds wel sullen accordeeren om de vreemdelingen metter daad buiten te sluiten, ende dat voordeel aan hare familien liever als aan vreemden te laten."

${ }^{257}$ Ibidem, $54-56$ : “... soo en weet ik niet wat een oligarchie is, indien men die hier niet ziet."

${ }^{25^{8}}$ Aanwysing III.5, p. 494: “... de cordate directie van de vroome Regeerders in Holland.” The chapters based on De Witt's concept are Interest, 29-30; Aanwysing III.5-6. 
situation in Holland at large and Leiden in particular, where the governing boards of the industrial halls, the university's senate, and the city's ruling council revealed the detriments of a closed oligarchy. The republican examples of the classical past and the Italian present, from Rome to Genoa, provided an interpretative framework to grasp the significance of this Dutch reality. The example of Ancient Athens underlies the brothers' discussion of the second alternative of republican rule: democracy, or to use its more common early-modern phrasing, 'popular government'. According to the De la Courts, the contrast between aristocracy and democracy is best epitomized in a phrase from Tacitus that constantly recurs in their works: Dominatio paucorum regiae libidini propior, populi imperium juxta libertatem est, "while the rule of the few approaches closely to a king's wantonness, a popular government stands near to liberty". 259

For the De la Courts, a true civil society that is established when people leave the state of nature must be such an imperium populi, based on the equality of all adult male contractors. They define this democracy, again in largely Aristotelian terms, as the government

where all people who are by nature not under someone else's custody, like Women and Children, have the power to appear in an assembly, and to issue laws there with the majority of votes, and to appoint the executives of those laws to whom every human has to pay obedience. ${ }^{260}$

Or, more succinctly, a democracy is a "Popular State or Government where every Citizen has his share in the Government, so that these citizens, being assembled, together constitute the sovereign Government". As I have argued in detail in the preceding chapter, the rationale of this popular government follows from the brothers' depiction of the human condition. Democracy is the most natural form of government because "all people, loving their own welfare, also believe to be wise enough to know in what it consists", and therefore they will never be satisfied with someone else

${ }^{259}$ Tacitus, Annals VI.42.2, quoted in this form (the original is vice versa) in Politike Weeg-schaal III.I.4, p. 530. The phrase is also quoted in Boxhorn, Institutiones I.3 Exp., p. 21.

${ }_{260}$ Politike Weeg-schaal I.I.6, p. 35-36: “... daar alle menschen, die van nature wegen onder een anders voogdye niet zijn, als Vrouwen en Kinderen, magt hebben, om in een vergaadering te verschijnen, en aldaar met de meeste stemmen, wetten en Executeurs der zelven te maaken, aan de welken yeder mensch gehoorsaamheit schuldig is, by de Ouden Demokratia genaamt." Cf. Burgersdijk, Idea oeconomicae et politicae II.XXIII.1, p. 120-121: "Democratia est status, in quo civium vel omnium, vel magnae partis nomine, quidam ad tempus caeteris omnibus in universum \& singulis imperant, \& jus majestatis, summamque potestatem exercent." 
deciding on their wellbeing. ${ }^{261}$ At the same time, democratic rule is confined to independent citizens only, and only male householders have the power to speak for themselves and thus fulfil the prime criterion of citizenship.

Does such a popular government maintain the advantages of plurality without suffering under its disadvantages? To answer this question, the Politike Weeg-schaal continues, after the extensive review of aristocratic government, to list all democracy's merits and flaws. This analysis starts with the contention that many of the characteristics of popular rule speak clearly in its favour. To begin with, a popular government is the original form of any polity. Unlike both monarchy and aristocracy, it is "not founded upon any violence, but natural, rational, and in itself fair". In his later revision, De la Court even maintained "that only in Democracy the perfect government can be found". ${ }^{262}$ The list of advantages continues with the contention that the Ciceronian maxim salus populi suprema lex will only be truly materialized in a popular government, for the majority of all citizens will by necessity agree on those issues that advance the wellbeing of the largest part of the community. Moreover, a popular government employs all human potential fully "so that nobody's capability or desire for honour ... is made fruitless". Since democratic magistrates are appointed for their quality and not for their ancestry,

all Citizens who excel in knowledge, virtue and wealth will therefore be all the sooner chosen as Magistrates, without being ... because of that excellence, hated and persecuted, as in Aristocratic, or rather killed, as in Monarchical Governments. Thus everyone here applies his utmost diligence to assemble sciences and goods. ${ }^{263}$

In short, a democracy cultivates and profits from the true self-love that defines human behaviour in a well-ordered civil society.

${ }^{261}$ Politike Weeg-schaal III.I.1, p. 518-519: “... de Populare Staat ofte Regeering, daar yder Burger sijn deel sulks aan de Regeering heeft, dat de zelve, vergadert zijnde, met malkanderen de souveraine Regeering uit maken ... dat alle menschen, haar eigen welvaaren beminnende, ook wjs genoeg meenen te zijn, om te weeten waar in het zelven bestaat."

${ }_{262}$ Ibidem III.I.4, p. 530: “... dat deese Populare Regeering op geen gewelt gefondeert, maar naturelik, redelik, en in zig zelven billik is." De la Court's addition is in the annotated edition in Amsterdam University Library, Ms. XXV C41: “... dat alleen in de Democratie de perfecte regeering kan gevonden werden."

${ }^{263}$ Ibidem, 531-534: “... zulks niemants bequaamheit, of eergierigheit in deze Populare Regeering wert vrugteloos gemaakt ... dat alle Burgers, die in kennisse, deugt, en rijkdom uitsteeken, daar door alleen eer tot Magistraats-persoonen zullen werden gekooren, zonder dat zy ... door die uitsteekentheit hier gehaat en vervolgt, gelijk als in de Aristokratike; of wel gedoot werden, gelijk als in Monarchale Regeeringen. Zulks een yder hier zijn uiterste vlijt aanwend, om weetenschappen en goederen by een te vergaaderen." 
This clear praise of popular government is highly remarkable, since the term democracy was used for centuries in an overtly negative way as the pejorative denominator of the disastrous rule by the multitude. ${ }^{264}$ Indeed, the De la Courts' appropriation of the term deviates significantly from the overtly disparaging remarks on democratic government in the traditional politica. Burgersdijk, for example, described democracy as "by its nature the most imperfect state", while Boxhorn similarly disclaimed the anarchic licentiousness when all share in the government. ${ }^{265}$ In the seventeenth-century Dutch Republic, only a few marginal authors proved to be more sympathetic to the idea of democratic government, and their arguments often involved mere carnavelesque casuistry. A good example of this stance is the curious little book Democratia Corporis Humani, published in 1640 by the Dutch medical doctor Petrus Baardt. Adopting the time-honoured metaphor of the body politic, Baardt argued that all parts of the human body are equally important for our physical well-being, including the 'lower' parts that we conceal and prefer not to speak about. Human beings thus have democratic bodies, Baardt concluded, and the same is true for the body politic: all members of society should participate in decision-making to maintain a healthy political structure. For Baardt, our bodies function like "an unspeakable well-ordered Democracy, in which the common People accords by agreement of votes. Who in the world could ordain a better established Republic than the one thus established by our High and Mighty Creator?"266

With similar wit and imagination but also with much more theoretical sophistication, the De la Courts develop this defence of democracy into an elaborate justification of popular rule, clearly departing from the conventions of the established politica. The importance of this move can hardly be overemphasized: it amounts to the first outspoken theoretical defence of democracy in the seventeenth-century Dutch Republic, and as such it forms an important steppingstone for Spinoza's argumentation on

${ }^{264}$ See John Dunn, Setting the People Free. The Story of Democracy (London: Atlantic, 2005), 55-59.

${ }^{265}$ Burgersdijk, Idea oeconomicae et politicae II.XXIII.11, p. 121: "Democratia est status natura sua imperfectissimus.” Cf. Boxhorn, Institutiones I.V Exp., p. 56; II.X.2, p. 356.

${ }^{266}$ Petrus Baardt, Democratia Corporis Humani; dat is, Leden-Stemminghe des Menschelijcken Lichaems; gevoegt op een Democratike Regieringe sommiger Republijken (Leeuwarden, 1640), adapted from [Adriaan Stikke], Leeden strydt (The Hague, 1630), 14: "Immer hebben niet minder onse Lichamen by sich een on-uyt-spreeckelijcke wel-gestelde Democratia, in de welcke het gemeene Volck over een comende in stemminge accordeert; wie doch ter Wereldt soude beter gestelde Republijck connen ordineren als nae welcke dien so Hoogmogenden Schepper alle dusdanige bestellinge heeft geordineert?" 
democracy in the 1670 . $^{267}$ Yet while the brothers' argument for democracy stands out for breaking new terrain, a strong residue of the age-old criticism remains in their claim that democracies suffer from one fundamental drawback: human ignorance. Whereas an aristocracy enjoys the benefit of well-educated rulers, a "Popular State, being ruled by the majority, is also truly ruled by stupid and ignorant people who have neither eyes nor ears". The most likely results are hasty and labile judgments, incomplete and extremist resolutions, while the "fervent eloquence" of a demagogue can easily convince the ruling assembly with populist sophistry. ${ }^{268}$ The main challenge that confronts popular government is therefore the issue of public deliberation. When everyone has a say, liable and truthful speech can easily be undermined by dangerous rhetoric that blurs the distinction between virtue and vice.

This centrality of the role of speech and the passions in democratic decision-making forms the core of the hesitant and somewhat inconclusive embrace of popular government in the work of the De la Courts. This embrace follows from the assertion that the passions of both true and false self-love "produce nowhere less detrimental fruits than in a Popular Government. Eliminating them completely is impossible and would also be entirely useless, since these passions cause endlessly more good than evil within the world". ${ }^{269}$ This crucial contention, close to the Augustinian acknowledgement of the benefit of the passions, is fully taken to heart in the grand finale of the first edition of the Politike Weeg-schaal - a passage most probably written by Johan de la Court. Having carefully balanced the pros and cons of the three Aristotelian forms of government as an impartial seeker for truth, he eventually deploys all his rhetorical skills to elicit the readers' agreement by mobilizing their passions: first through a number of colourful fables that illustrate the argument, and then by turning directly to the audience with a powerful interrogative anaphora that enhances the inevitability of his conclusion. The passage is worth quoting at length since it clearly reveals how the authorial ethos of rationality merges with a passionate rhetoric that directly addresses the reader with the question:

\footnotetext{
${ }^{267}$ See Israel, "Intellectual Origins," and cf. the Conclusion below.

${ }^{268}$ Politike Weeg-schaal III.I.5, p. 542-544: "Dat een Populare Staat, werdende geregeert van het meestendeel, ook waarelik geregeert werd van domme en onweetende menschen, nog oogen, nog ooren hebbende ... met heftige welspreekentheit."

${ }_{269}$ Ibidem III.II.4, p. 627-628: “... die passien brengen nergens min schadeliker vrugten voort, als in een Populare Regeering: in het geheel die weg te neemen, is onmogelik, en soude ook gansch ondienstig zijn, also gemelde passien oneindelik meer goeds als quaads in de wereld veroorsaken."
} 
Whether it isn't true that in Monarchical Governments the Lord ... ruling on his own (which would be the most detrimental of all Governments), in general wants to rule to the disadvantage of his Subjects, according to the Monarchical maxim: Divide, impera. Pour faire un grand Roy, il faut diviser le peuple? Whether it isn't true that in Aristocratic Governments the Rulers ... always can, will, and shall employ their knowledge and power of Government ... to protect and enhance themselves, also with, and through the ruin and decline of the common Subjects? Whether it isn't true that only in Popular Governments the Rulers (namely, not the Magistrates, Servers of the State; but the People, with whom Sovereignty is there) search (Salus Populi suprema Lex) their own welfare, the one of the common Inhabitants? [note the subtle change from 'subjects' to 'inhabitants'] ... And whether therefore the Monarchical Government should not be esteemed very little? Whether the Aristocratic Government should not be placed far above the Monarchical? Whether the Popular Government is not evidently more advantageous to the Inhabitants and therefore better than the Aristocratic? ${ }^{270}$

Thus finishes the first edition of the Politike Weeg-schaal, with a rhetorical move that, in engaging the audience to decide for itself, underscores the work's eventual conclusion: if guided by the trustworthy speech of the wise merchant, the common people should be considered judicious enough to make their own decisions.

Yet when preparing a new edition of the work after Johan died, Pieter de la Court did not seem to be entirely confident about the form as well as the contents of his bother's conclusion. Is the independent judgment of the general public really to be trusted? De la Court doubted it, as he equally doubted whether his brother's open plea for democracy could persuade the powers-in-being as a feasible alternative for the established oligarchy in Holland. Accordingly, De la Court attached a couple of additional chapters that modify Johan's initial conclusion as well as his democratic rhetoric. In a striking change of tone, De la Court takes the reader

${ }^{270}$ Ibidem III.III.1, p. 639-640: “Of niet in Monarchaale Regeeringen de Heer ... (het welk het schaadeliksten van alle Regeeringen soude weesen) selfs regeerende, gemeenelik regeeren wil, tot nadeel zijner Onderdaanen, volgens de Monarchale maxim? Divide, impera. Pour faire un grand Roy, il faut diviser le peuple ... Of niet in Aristokratike Regeeringen de Regeerders ... altijds alle hare kennisse, en magt der Regeeringe konnen, willen, en sullen gebruiken ... om haar zelven te bewaaren en te vergrooten, ook met, en door den ondergang, en vermindering der gemeene Onderdaanen. Of niet alleen, in Populare Regeeringe, de Regeerders (namentlik, niet de Magistraats-persoonen, Dienaars van den Staat; maar het Volk, by wien aldaar de Souverainiteit is) soeken (Salus Populi suprema Lex, ) haar eigen, der gemeene Ingesetenen welvaren? ... En of dienvolgende de Monarchaale Regeeringe niet behoorde te wezen zeer weinig geagt? Of niet de Aristokratike Regeering verre boven de Monarchaale behoorde te werden gesteld? Of niet de Populare Regeering, kennelik, den Ingesetenen voordeeliger, en dienvolgende beeter is als de Aristokratike." 
firmly by the hand, adding a paternalist assertio to the text's original reliance on the reader's own judgment. First, De la Court explains the "Reasons why the Popular Government has been depicted so favourably until now, although it is truly not the best one". Then he continues to insist that, although a popular assembly is obviously better than an oligarchy, it does suffer heavily from the ignorance of its members. Therefore, as he concludes resolutely, "an Aristocracy that is closest to the Popular Government is surely the best Government". ${ }^{271}$

At first sight, this modification of the argument seems to entail a blatant contradiction of the initial embrace of democracy. Indeed, Kossmann maintained that in revising the Politike Weeg-schaal, De la Court unjustifiably and wilfully killed his brother's democratic darlings. ${ }^{272}$ However, as both Haitsma Mulier and Blom have argued, such a portrayal of the development of the brothers' thought is not very convincing. In Blom's words, the "change is one of emphasis more than of principle":273 De la Court's additions mainly tried to resolve a tension that characterizes his brother's use of the term popular government from the start. The first edition of the Politike Weeg-schaal overtly embraced democracy as the best form of government, but it also stressed that "one should make a very large distinction between an illegitimate rebellious assembly of the people ... and a lawful assembly of the common Citizenry". This distinction is clarified by a Latin saying, "inter populum \& multitudinem differentia permagna est", which reveals that a popular government (i.e. a government by the citizenry, the populus) should not be equated with a government of the unruly rabble, the multitudo. ${ }^{274}$ Hence, for both brothers De la Court a popular government does not entail a government by all, but rather a government consisting of the select group of men who qualify as citizens. This definition is largely in line with the conventional seventeenth-century denotation of popular rule. Althusius, for example, argued that a democraticus status requires a ratio gubernandi aristocratica, a

${ }^{271}$ Ibidem III.III.3-5, p. 652, 661: "Reedenen waarom de Populare Regeering voor desen zo gunstig is voorgestelt geweest; hoewel die warelik de beste niet zy ... Dat een Aristokratie, die allernaast aan de Populare komt, gewisselik de beste Regeering is."

${ }^{272}$ Kossmann, Political Thought, 70 , note 3.

${ }^{273}$ Blom, Morality and Causality, 179, note 39. See also Haitsma Mulier, Myth of Venice, 141-142, 145 .

${ }^{274}$ Politike Weeg-schaal III.I.6, p. 561-562: “... (inter populum \& multitudinem differentia permagna est) dat men zeer groot onderscheid maaken moet tusschen een onwettige oproerige vergaderinge, des volks ... en tusschen een wettige vergaaderinge der gemeene Burgerschap." Cf. also Aanwysing I.2, p. 19: “... eene multitudo, meenigte buiten civili societeit en regeering leevende." 
government of optimi. ${ }^{275}$ Similarly, across the North Sea, a 'popular' republican like Nedham equally stressed that "when we mention the People, observe all along, that we do not mean the confused promiscuous Body of the People". ${ }^{276}$

Accordingly, De la Court's additions to his brother's initial conclusion did not involve a radical shift, but rather a clarification of the argument. The reason for this clarification stems in particular from his continuous rethinking of the importance of speech in politics - a process that is reflected in the change in rhetoric, from Johan's initial interrogatio to Pieter's eventual assertio. When revising the work, De la Court increasingly stressed that the members of a truly popular assembly will be easily carried along "by eloquent Orations". ${ }^{277} \mathrm{~A}$ republican government should therefore be established thus "that no Citizen is ever allowed to practice his eloquence by debating anything before the people". ${ }^{278}$ This rising concern about the possible abuse of public speech echoes a similar argument in Harrington, who equally warned that "any commonwealth where the people in their political capacity is talkative" will be "carried away by vainglorious men". ${ }^{279}$ De la Court's concern also resulted in the same claim as in Harrington's Oceana that all voting should be secret and based on a system of blind balloting as in Venice, so that rhetorical manipulation and intimidation are impossible and "the common interest of the Republic will always be promoted" ${ }^{280}$ Eventually, De la Court's unease with the role of eloquence led him to a tentative plea for a bicameral solution, again like in Harrington, with a senate that debates and proposes its advice to a general assembly. This assembly has no debating powers but only the ultimate right of decision, "because the people are then not being misled by any eloquence of any eminent Citizen who tries to embellish his own particular advantage as if it were a common one". ${ }^{281}$ Yet this gradual move

${ }^{275}$ Althusius, Politica XXXIX, quoted in Conti, "Modelli repubblicani," 63.

${ }^{276}$ Nedham, Excellencie, 71.

${ }^{277}$ Politike Weeg-schaal III.III.3, p. 656: “... welspreekende Oratien.”

${ }_{278}$ Amsterdam University Library, Ms XXV C41, addition to Politike Weeg-schaal III.I.6, p. 573: “... dat geenen Borgere ooit geoorlofd zy syne welspreekendheid te oeffenen nmet iets voor den voke te debatteren."

${ }^{279}$ Harrington, Oceana, 149.

${ }^{280}$ Ibidem II.IV.12, p. 421: “... dat in de zelven het gemeen interest der Republike altijds zal werden betracht." See also Politike Discoursen I.I.1, II.V.2, II.V.7. Cf. Harrington, Oceana, 114-118, and see Haitsma Mulier, Myth of Venice, 152-153.

${ }^{281}$ Amsterdam University Library, Ms XXV C41, addition to Politike Weeg-schaal III.I.6, p. 566: “... also 't volk alsdan door geen welspreekendheid van eenig aansienelik Borger, die syn eigen particulier voordeel als of het een gemeen waar tragt op te pronken, milseid werdende." 
towards a constitutional arrangement that avoids the pitfalls of public speech remained inconclusive. Unlike Harrington, who extensively discussed the intricacies of the voting procedures in his model of Oceana, ${ }^{282}$ the brothers De la Court did not enter into detail about the practical realization of their ideal republican government.

\section{A Government of Merchants, by Merchants, for Merchants}

The De la Courts' vision of the ideal republican assembly does not so much follow from a well-defined constitutional design as from their general argument that commerce must prosper in liberty. Their main goal is to make clear that the government should be in the hands of and for the sake of those who further the interest of trade. At the basis of this correlation between politics and commerce lies the idea that the concerns of trade correspond to the concerns of the commonwealth as such. De la Court explicitly compares civil society to the establishment of a commercial company, for both are founded on "this Fairness, that to every one of the Participants ... belongs his share in the future Profits and Losses ... and that there is such an equality among the Participants that none of them can disregard this Fairness and these conditions". De la Court then continues to assert that were these criteria of fairness also to be met in politics, "there would not be seen so many unequal Societies of common Inhabitants with Great Lords, of Merchants, Citizens and Farmers with Kings, Monarchs, Noblemen, and Soldiers" ${ }^{283}$ In other words, the organisational principles of a well-ordered commercial company, based on equality, reveal how to overcome a disproportionate distribution of power in the political realm. ${ }^{284}$

${ }^{282}$ See Harrington, Oceana, esp. 78-80. On Harrington's exceptional attention to constitutional arrangements, see Scott, Commonwealth Principles, 141-143; and Idem, "Classical Republicanism," 64-65.

${ }_{283}$ Sinryke Fabulen, 78-79: "Soo maaken sy alsdan Maatschappien, ende bouwen die in het aangaan der selven altijds op deese Billikheid, dat yder der Maats ... ook sijn aandeel der toekoomende Winsten ende Schaaden behoorde ... ende onder de Maats soodaanige gelijkheid zy, dat geen der selven deese Billikheid ende Voorwaarden mooge veragten ende straffeloos breeken ... Het welk, indien wel behertigd werd, soo soude men niet sien soo veele ongelijke Maatschappien, van gemeene Ingeseetenen met Groote Heeren, van Koopluiden, Borgers ende Boeren, met Koningen, Vorsten, eedelen, ende Krijgs-luiden."

${ }^{284} \mathrm{Cf}$. the elaborate statute drafted by De la Court for the establishment of a mercantile company as an alternative to the VOC in Overvoorde (ed.), "De Noord-Oostelijke doorvaart," 305-311. The statute, which consists of fifty organisational principles, particularly emphasises the equality between the members of the company, the principle of majority rule, rotation of office and the various ways to counter a conflict of interests. 
This parallel between commercial equality and republican politics ultimately implies that a republic of trade where wise merchants govern preserves the fundamental harmony of private and public interests. For the brothers De la Court, the capricious nature of trade makes excessive wealth unattainable and thus guarantees a fairly equal distribution of power and property. In a commercial commonwealth like Holland, individual riches are based on "Movable goods", which means that possessions are so insecure that "in no other country on the whole surface of the Earth there have been as many cases of being Rich and becoming Poor" ${ }^{285}$ The political consequences of this uncertainty are highly positive. Since it is impossible to attain excessive wealth, "there will be no room" in a commercial commonwealth for "everything that makes a Monarch jealous". Moreover, the contingency of commercial property implies that the "citizens of the popular Government, noticing that they only become distinguished in government by their reason, virtue, and Wealth" will educate their children "in all knowledge, sciences, and virtues". ${ }^{286}$ Thus commerce has an effect comparable to the agrarian law proposed by Harrington: it establishes a balance of dominion and enhances continuous competition on the basis of merit instead of covetousness. ${ }^{287} \mathrm{~A}$ large assembly of merchants will therefore not succumb to monarchical greed, but instead enable all people "to search for their advantage in satisfactory freedom, and while they surely own what they have, everyone is diligent to gain still more". The overall result is the increase of commerce and industry and the growth of the population, the true sources of grandezza of a republic of trade. ${ }^{288}$

Accordingly, the governing assembly of a commercial commonwealth should consist of all citizens who can be expected to enhance this general interest of trade - those, that is, who would go against their own interests if they would impose exorbitant taxes or wage costly wars. The larger this assembly is, the better, "for if there are many in the Government and

${ }^{285}$ Sinryke Fabulen, 462: “... in Losse goederen ... Soo heeft men ook in geenen Lande des geheelen Aardboodems soo veele ge- ende vervallen van Rijk te zijn, ende Arm te werden."

${ }^{286}$ Politike Discoursen II.V.9, p. 136-137: “... alle het geene aan een Monarch jaloesie geeft, heeft in haar geen plaats ... Maar dese Burgers der populaire Regeeringe, siende dat sy door haar verstand deugd, en Rijkdom, alleenlik aansienelik in Regeering werden ... voedense in alle kennisse wetenschappen ende deugden op."

${ }^{287}$ Harrington, Oceana, 100-114. Cf. Haitsma Mulier, Myth of Venice, 164-165.

${ }^{288}$ Politike Discoursen II.V.9, p. 138: “... soo mogen sy in genoegsame vryheid haar voordeel soeken: en dewijl sy seekerlik besitten, 't gene sy hebben, soo is een yder vlytig, om nog meer te winnen." 
everyone follows his interest, the Community enjoys the advantage of all those interests, whereas otherwise they only enjoy the interest of the Monarch" ${ }^{289}$ Yet there is a clear limit to the size of the assembly. As the De la Courts maintain, the private interests of the lower social strata and of guild masters in particular do not represent the general interest of society. Government must therefore be in the hands of "many of the eminent Citizens", ${ }^{290}$ the independent male householders who know how to relate their private advantage wisely to the common good. Speaking freely for those who depend on them, these wise merchants will enhance by majority of votes the welfare of all, for

the legislative Power is shared by so many and so diverse Men, who, representing or substituting the entire People not only with words but truly in fact, can only practise their own Welfare by promoting at the same time the Welfare of the entire People. ${ }^{291}$

Thus the harmony between private and public interests is preserved if the entire population is represented by a broad assembly. Such an assembly, as De la Court once more emphasized in the Sinryke Fabulen, is "truly the very best form of Government" the more it approaches democracy and the more it deviates from monarchy. ${ }^{292}$

The De la Courts' plea for a merchant democracy - a government of merhants, by merchants, for merchants - involved a significant move towards opening up the Dutch oligarchy in power. Clearly alluding to the situation in Leiden and Holland at large, the De la Courts asserted that their model implied that the "number of sovereign Councillors ought in a moderate City be no less than two hundred" - at least five times the number of Leiden's existing council. ${ }^{293}$ This criticism of the Dutch status quo, with its emphasis on popular sovereignty and gradual opening towards democracy, inaugurated a 'popular turn' in Dutch republicanism during the 1660 s and 1670s, developed further in the work of Van den Enden and

${ }^{289}$ Ibidem, 139: "Want dewijl er veelen in Regeering zijn, en ene yder sijn interest vervolgd, geniet de Gemeente het voordeel van alle die interesten, daar Sy andersins maar het genot van het interest des Monarchs geniet."

${ }^{290}$ Ibidem: “... veele der voorneeme Borgers."

${ }^{291}$ Sinryke Fabulen, 320: “...de wet-geevende Magt is by soo veele ende soo veelerlei slag van Menschen, dat die niet alleen met woorden, maar waarelik ende in der daad, het geheele Volk representeerende ofte vervangende, niet konnen haar eigen Welvaaren betragten, dan meteenen het Welvaaren des geheelen Volks te besorgen."

${ }^{292}$ Ibidem, 75: "Sulks dit waarelik de allerbeste forme der Regeeringe is."

${ }^{293}$ Ibidem I.I.1, p. 17: "Dit getal der souveraine Raads-Heeren behoord daarom in een matelike Stad, niet min als twee honderd te zijn." 
Spinoza (see the conclusion below). Arguably, the De la Courts thus stood at the roots of an important tradition in Western political thought which continued throughout the Enlightenment.

Yet we should be warned not to equate the brothers' argument for a broad ruling assembly with the late eighteenth-century arguments for a representative democracy. The brothers De la Court still remained firmly within the Athenian paradigm of the city-state where the independent citizenry engages in direct decision-making. Their plea for a large ruling assembly did not depart radically from Aristotle's claim that the ideal politeia entails a perfect fusion of oligarchy and democracy, nor from Boxhorn's claim that Holland should be ruled by an open and broad aristocracy of the rich. ${ }^{294}$ To a large extent, the De la Courts followed this line of reasoning, tentatively moving in a more democratic direction. Their originality lies mainly in the outspokennes with which they tried to free the term 'democracy' from its long-standing negative connotations. With the De la Courts, democracy started its slow but spectacular rise that changed it from a derogatory description of anarchy into the universal denominator of legitimate rule. Yet the brothers' description of what a popular government exactly entails was not particularly innovative. After all, the most fundamental and pioneering aspect of their criticism of the Dutch status quo was their categorical rejection of the Stadholderate, which amounted to perhaps the most radical argument against monarchy in Ancien Régime Europe.

\section{Conclusion: The RAdicAl Republic}

The republican thought of the brothers De la Court merges the idea that freedom of trade is the essence of commercial reason of state with a comprehensive criticism of monarchy in all its guises. Following the claim that all people are self-interested, good government must be based on a harmony between the private interest of those who rule and the public interest of society at large. Since monarchs are by necessity the enemies of commerce, such a harmony can only be preserved if the sovereignty remains in theory and in practice with a large assembly of eminent citizens, who represent all the individual interests in society without giving in to any individual domination. Only in such a broad aristocratic

${ }^{294}$ Boxhorn, Institutiones II.5, p. 329-330. Cf. Aristotle, Politics IV.8 (1293b-1294a), and see the extensive analysis in Nieuwstraten, "Why the Wealthy Should Rule." 
republic commerce will thrive in liberty and thus increase the greatness of the commonwealth. Hence, the interest of trade lies at the basis of the two fundamental features of the De la Courts' republic: its radical antimonarchism and its gradual opening to democracy.

The significance of the way in which the brothers De la Court connect an argument for commerce with an argument against monarchy is especially apparent in comparison with their contemporary republicans across the North Sea. As shown above, the English republican experiment of the 165 os did not play an important role in the thought of the De la Courts. There is no evidence that they were familiar with English republican treatises apart from, most likely, Milton's Defensio and, in a later stage, Harrington's Oceana. Yet both Milton and Harrington had a strikingly different appreciation of commerce than the De la Courts. Milton emphasized emphatically that trade could never be a reason "to prostitute religion and libertie"; ${ }^{295}$ Harrington claimed that although "in manufactures and merchandise the Hollander has gotten the start of us", the English Commonwealth had "a far more sure and effectual foundation" because it was based on agriculture. ${ }^{296}$ Other English republican theorists from the 1650 s and 166os, most notably Marchamont Nedham and Algernon Sidney, were much closer in their argumentation to the brothers De la Court. Nedham's 1656 "Commonwealth-Principles" show many similarities to the thought of the De la Courts - from the claim that republican magistrates will "have made the Publick Interest, and their own, all one", to a rhetorical plea for a broad aristocratic government close to Athenian democracy. ${ }^{297}$ In the following decade, Sidney's Court Maxims continued to stress the republican harmony of private and public interests in similar terms, now with explicit attention to the importance of trade. As Jonathan Scott has shown in detail, Sidney's adaptation of this language of commercial interest was deeply informed by his exile in the Dutch Republic at the start of the $1660{ }^{298}$ Sidney frequently praised the republican example of the Dutch, emphasizing that it is "the king's interest to destroy trade"

295 Milton, Readie and Easie Way, 443.

${ }^{296}$ Harrington, Oceana, 198.

297 Nedham, Excellencie, 82, 191-192.

${ }^{298}$ Jonathan Scott, Algernon Sidney and the English Republic, 1623-1677 (Cambridge: Cambridge University Press, 1988), 210-221. See also the comparison between De la Court and Sidney in Charles-Édouard Levillain, "L'Angleterre de la Restauration au miroir de la 'vraie liberté' (1660-1672). La rencontre entre republicanismes anglais et hollandais à travers les écrits de Pieter de la Court," E-rea 1.2 (2003), from http://erea.revues.org/index205. html [retrieved May 13, 2011]. 
while Holland's prosperity and power were due to its "good government and liberty of traffic" - two crucial claims that also dominate the work of the brothers De la Court. ${ }^{299}$

There was therefore a significant congruence between the republican thought on either side of the North Sea, where the languages of liberty, interest and trade merged into a comparable republican interpretation of the gradual commercialization of society. Scott has argued compellingly that this common Anglo-Dutch republican project "emerged from a connected practical, as well as intellectual context", from a shared late humanist culture and related political and economic developments. For Scott, the resulting anti-monarchism in England and the Dutch Republic "was almost identical", but what separated Dutch and English republicans was their different assessment of the role of reason and the passions: while "Dutch republicanism focused on the constitutional management of the passions, for public prosperity and peace, English republicanism entailed a warlike championship of reason". ${ }^{300}$

Yet Scott's lucid comparison covers only a part of the story, because in spite of the similarities, the anti-monarchism of the De la Courts entails a decisively more radical, or 'exclusivist', twist than its contemporary English counterpart. ${ }^{301}$ First of all, it is important to stress that the domestic backgrounds of Dutch and English republican thought, though related, differed significantly. The Dutch political debate between Orangists and anti-Orangists was not, as in England, a debate between monarchists and supporters of the commonwealth, but it was rather a contest between two different visions of republican liberty. The anti-monarchism of the brothers De la Court did not emerge in response to royalist claims, as for example Nedham's, but instead to counter the equally republican argument that the Stadholder fulfilled the balance in the Dutch body politic. As a result, the De la Courts claimed on the basis of their analysis of commercial reason of state that all sorts of single rule, even within a republican constitution, entail the establishment of tyranny and servitude. This is why they insisted that there was no fundamental difference between the Dutch Republic under a Stadholder or Captain-General and the Ottoman

\footnotetext{
299 Sidney, Court Maxims, 73, 161.

${ }^{300}$ Scott, "Classical Republicanism," 62, 69, 71. For the impact of the Dutch republican example in England, see esp. Idem, Commonwealth Principles, 353-357.

${ }^{301}$ On exclusivist republicanism in the Renaissance, see Hankins, "Exclusivist Republicanism." See also Nelson, Hebrew Republic, 23-56, which slightly overstates the anti-monarchism of English republicans like Milton.
} 
Empire under the Sultan, for even the looming threat of the desire to dominate brings about the demise of republican and commercial liberty.

This categorical rejection of any form of personal authority goes far beyond the republican claims of the De la Courts' English contemporaries. Milton took care not to equate monarchy with tyranny, stressing that "both the name and the power of a king are entirely consistent with a greater power in the people and the law". ${ }^{302}$ In comparable vein, Harrington emphasized the pre-eminent role of a "Lord Archon" as "the sole legislator of Oceana". Directly contradicting the anti-Orangism of the De la Courts, he argued that "the Low Countries under a monarch were poor and inconsiderable, but in bearing a prince, could grow unto a miraculous height" ${ }^{303}$ Even Nedham, who was arguably the fiercest (and most opportunistic) anti-monarchical activist in England, justified a form of elective monarchy. In his words, "if any Kingly Form be tolerable, it must be that which is by Election, chosen by the Peoples Representatives" - a government that the De la Courts would have characterized as merely tyranny in disguise.$^{304}$ Finally, also Sidney stressed that he "dare[d] not say all monarchy is absolutely unlawful", since legal kingship is just and virtuous, as opposed to the outright "despotical government that is exercised over slaves". ${ }^{305}$ In short, all the main English republicans of the 1650 s and 1660 s targeted a corrupted monarchy, not monarchy as such. The categorical anti-monarchism of the brothers De la Court, which remained remarkably consistent from 1660 to 1685 , thus proves exceptionally far-reaching and exclusivist in comparison with their contemporaries across the North Sea.

Following their critical analysis of the economic policies of Leiden, the brothers De la Court constructed a commercial theory of reason of state that, modelled on Ancient Athens, pursues a republican empire of trade. The highest law of that empire is a comprehensive notion of liberty, which merges freedom from interference with freedom from arbitrary domination as the main characteristic of a true republic. Such liberty can only be maintained within a governmental framework where the rulers enhance the common good of society by searching for their private advantage. This harmony of interests is by definition unattainable in a state where one single man rules: monarchy in all its guises, including the Dutch

\footnotetext{
${ }^{302}$ Milton, Defence, 233.

${ }^{303}$ Harrington, Oceana, 67, 257.

304 Nedham, Excellencie, 69, 170.

305 Sidney, Court Maxims, 193, 199.
} 
Stadholderate, necessarily amounts to tyranny. In contrast, a true republic entails a government of many, a government for trade that represents all individual interests in society, impervious to the tyranny of one as to the anarchy of all. How then is it possible to preserve such a harmonious model of republican rule in an open society characterized by pluralism and latent conflict? This question is addressed in the next and final chapter, which turns to the central notions of social concord and religious toleration in the political thought of the brothers De la Court. 